\title{
Historical Review of Long-Term Soil Sampling for Environmental Surveillance at the Hanford Site and Vicinity
}

K. R. Price

W. H. Rickard

August 1997

Prepared for

the U.S. Department of Energy

under Contract DE-AC06-76RLO 1830

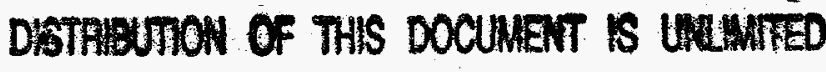
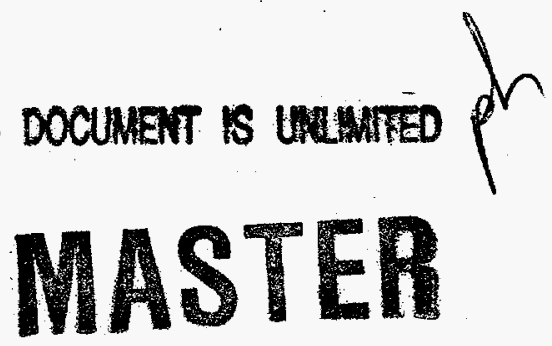

Pacific Northwest National Laboratory

Richland, Washington 99352 


\section{DISCLAIMER}

This report was prepared as an account of work sponsored by an agency of the United States Government. Neither the United States Government nor any agency thereof, nor any of their employees, make any warranty, express or implied, or assumes any legal liability or responsibility for the accuracy, completeness, or usefulness of any information, apparatus, product, or process disclosed, or represents that its use would not infringe privately owned rights. Reference herein to any specific commercial product, process, or service by trade name, trademark, manufacturer, or otherwise does not necessarily constitute or imply its endorsement, recommendation, or favoring by the United States Government or any agency thereof. The views and opinions of authors expressed herein do not necessarily state or reflect those of the United States Government or any agency thereof. 


\section{DESchamiar}

Portions of this document may be illegible in electronic image produets. Images are produced from the best avaitable origion docoment. 


\section{Summary}

Soil samples have been collected routinely from the environs of the Hanford Site and analyzed since 1971. Correct interpretation of results depends on samples being collected from the same locations, the locations remaining relatively undisturbed, and collection and analytical procedures remaining the same or being equivalent. Historical files, documents, and annual environmental reports were reviewed to evaluate these factors. It was determined that 20 soil sampling locations, 11 onsite and 9 offsite, were established between 1971 and 1977 and represent long-term sampling locations. Sample collection and analytical procedures have remained essentially the same since 1971. The physical and ecological attributes of each long-term soil sampling location were evaluated.

During the review of historical records, a few results for 1970, 1971, and 1972 were noted as previously unreported in annual or special reports. These results are included in Appendix A. To complete the record, results previously reported in annual environmental reports are given in Appendix B. Global Positioning System (GPS) readings for 20 long-term soil sampling locations are provided in Appendix C. 



\section{Contents}

Summary $\ldots \ldots \ldots \ldots \ldots \ldots \ldots \ldots \ldots \ldots \ldots \ldots \ldots \ldots \ldots \ldots \ldots \ldots \ldots \ldots \ldots \ldots \ldots \ldots \ldots \ldots$

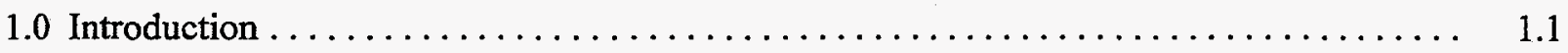

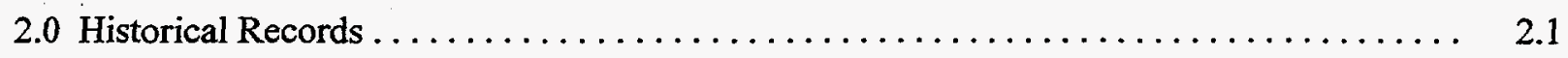

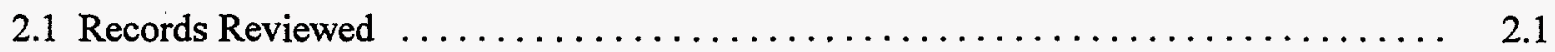

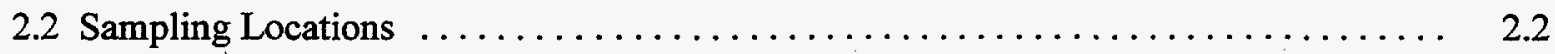

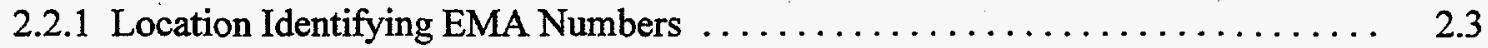

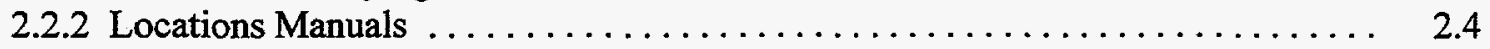

2.2.3 Master Schedules and Annual Environmental Reports $\ldots \ldots \ldots \ldots \ldots \ldots \ldots . \ldots \ldots$

2.2.4 Summary of Information on Sampling Locations $\ldots \ldots \ldots \ldots \ldots \ldots \ldots \ldots$

2.3 Sample Collection Procedures $\ldots \ldots \ldots \ldots \ldots \ldots \ldots \ldots \ldots \ldots \ldots \ldots \ldots \ldots \ldots \ldots \ldots$

2.3.1 Annual Environmental Surveillance Reports and Special Reports $\ldots \ldots \ldots \ldots \quad 2.7$

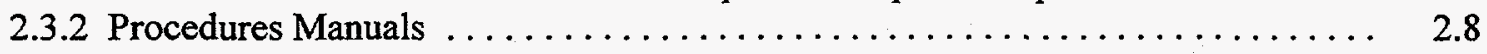

2.3.3 Summary of Information on Sample Collection Procedures $\ldots \ldots \ldots \ldots \ldots \ldots$.

2.4 Analytical Procedures . . . . . . . . . .

2.4.1 Summary of Information on Analytical Procedures $\ldots \ldots \ldots \ldots \ldots \ldots \ldots \ldots$

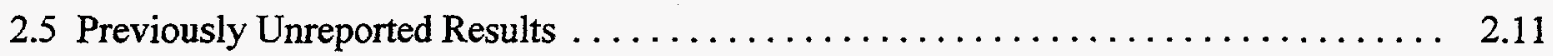

2.5.1 Summary of Unreported Results Listed in Appendix A $\ldots \ldots \ldots \ldots \ldots \ldots \ldots 2.11$

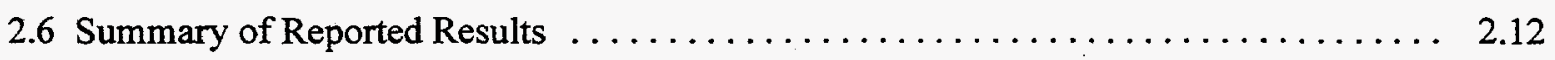

2.7 Conclusions for the Review of Historical Records $\ldots \ldots \ldots \ldots \ldots \ldots \ldots \ldots \ldots$

3.0 Evaluation of Long-Term Sampling Locations $\ldots \ldots \ldots \ldots \ldots \ldots \ldots \ldots \ldots \ldots \ldots \ldots \ldots$

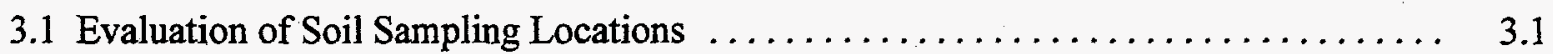

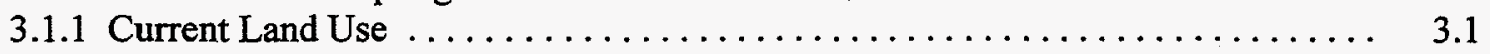

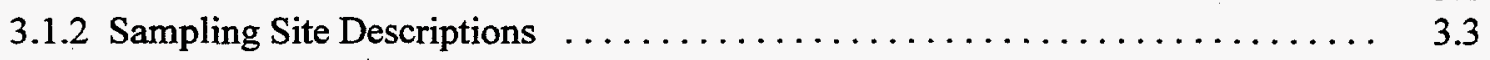

3.2 Field Records for Each Soil Sampling Location $\ldots \ldots \ldots \ldots \ldots \ldots \ldots \ldots \ldots \ldots$

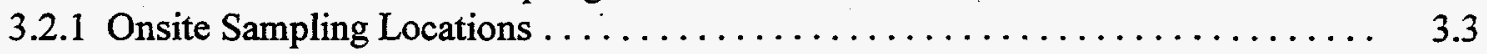

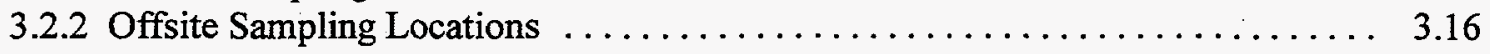

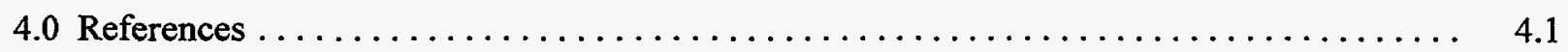


Appendix A - Summary of Unreported Soil Sampling Results $\ldots \ldots \ldots \ldots \ldots \ldots \ldots \ldots \ldots$ A.1

Appendix B - Results for 20 Long-Term Soil Sampling Locations $\ldots \ldots \ldots \ldots \ldots \ldots \ldots \ldots$ B. 1

Appendix C - Global Positioning System Readings for 20 Long-Term Soil

Sampling Locations .

\section{Figure}

3.1 Long-Term Soil Sampling Locations at the Hanford Site and Vicinity $\ldots \ldots \ldots \ldots .2$ 


\subsection{Introduction}

Radioactive materials have been released into the atmosphere from some facilities at the Hanford Site since operations began in the early 1940 s. Materials released into the atmosphere are eventually deposited onto the soil surface. Soil sampling has been conducted routinely since 1971 in both the onsite and offsite environments at Hanford. One of the stated purposes of soil sampling is to detect the presence and long-term buildup of long-lived radioactive materials. This objective can be attained only when samples are collected periodically from the same locations, when the soils remain relatively undisturbed, and when samples are collected and analyzed using the same or equivalent procedures. A review of these factors is the principal subject of this report. Previous reviews have addressed the first 5 years of soil sampling (Miller et al. 1977), reviewed soil sampling results through 1987 (Price 1988), and provided a statistical evaluation of soil sampling results for the period 1983 through 1993 (Poston et al. 1995).

Soil sampling outside the boundaries of Hanford operational areas has been the responsibility of the Pacific Northwest National Laboratory $(\mathrm{PNNL})^{(\mathrm{a})}$ since routine sampling began in 1971. Environmental surveillance (monitoring) personnel collected the samples, and results were summarized and reported in annual environmental reports. Samples were analyzed initially by the U.S. Testing Co., Inc., a government contractor and subsequently a subcontractor to PNNL, and later by Quanterra Environmental Services, Inc., a subcontractor to PNNL. Analytical results were retained in computerized data bases as well as recorded in handwritten logbooks for backup. The locations of sampling sites and the procedures for collecting and analyzing samples have been documented since the late $1970 \mathrm{~s}$. The first part of this report presents the results of a review of environmental monitoring program historical files, documents, and annual environmental reports. The second part provides a review and current evaluation of the physical and ecological attributes of each long-term soil sampling location.

(a) Formerly the Pacific Northwest Laboratory (PNL), operated for the U.S. Department of Energy by Battelle Memorial Institute. 


\subsection{Historical Records}

Environmental monitoring program historical files, documents, and annual environmental reports were reviewed for information on the following issues:

- Have soil sampling locations been relocated over the years (i.e., have sampling sites been moved a considerable distance while retaining the same literal names and/or location identifying numbers)?

- Have soil sampling procedures changed significantly over the years (i.e., have larger or smaller samples been collected or have samples been collected deeper or shallower compared to current techniques)?

- Have significant changes occurred over the years in analytical procedures used to detect plutonium in soil samples or to report data (i.e., have changes occurred in analytical procedures or data reporting techniques that could influence the interpretation of results for plutonium detected in soil samples)?

- Have all significant results for plutonium and other important long-lived radionuclides detected in soil samples been reported in annual or special reports (i.e., have all results been reported relevant to the interpretation of plutonium and other important long-lived radionuclides occurring in soil samples collected offsite)?

\subsection{Records Reviewed}

An effort was made to find as many historical records as possible regarding soil sampling, analyses, and results. Records were reviewed to identify historical sampling locations, the reasons for sampling, analytical results, and any other relevant information. A search for results from plutonium analyses was emphasized because of the long-lived nature of most plutonium isotopes, but results for strontium- 90 and cesium- 137 were noted also.

The following records were located and reviewed:

- Memos, letters, and miscellaneous papers in the archives of historical records for the environmental monitoring program

- "Specials" - notebooks in the archives of historical records containing information and results for special purpose samples collected from 1967 through 1974

- "Soil, Sediment and Vegetation," a handwritten logbook of results and information on sampling from 1971 through 1989 in the archives of historical records 
- Documentation about historical computer systems and isotope identification codes located in a box of records retrieved from storage

- A copy of the original Environmental Sampling Locations Manual (Blummer 1979), and subsequent versions (PNNL 1983; PNNL 1991) ${ }^{(a)}$

- Sample collection procedures found in Environmental Monitoring Procedures (Blummer 1981), a subsequent revision (Price et al. 1986, Hanf 1995)(a)

- Master schedules and annual reports for 1971 and subsequent years.

\subsection{Sampling Locations}

The name of one sampling location in the historical record was noted as representing a different location than is in use today. A sampling site known as the "Yakima Barricade" was originally located at the site boundary on State Route 24, 3.3 miles west of the present Yakima Barricade. It was also known as the "West Intersection of Rt. No. 24 and Plant Boundary." However, this location was used before routine soil sample collection was established in 1971. The current Yakima Barricade soil sampling site is located a few hundred yards north of the Hanford Site Yakima Barricade guard house, near the existing air sampling station.

Minor adjustments to literal names have also been made over the years. For example, "ALE," "East of Arid Land Ecology Lab," and "ALE Field Lab;" "0.5 Mile NE of FFTF," "NE FFTF," and "400E;" and others. A complete list of also known as (a.k.a.) names is provided in Section 3.0, "Evaluation of Soil Sampling Locations."

More important, however, is whether or not routine soil sampling locations were changed after 1971 without changing the literal names. The use of location names was traced by examining the computer systems used to manage information for the environmental monitoring program and the various types of documentation recorded for those systems.

Since 1971, sampling locations have been mostly standardized, and analytical results have been stored in information data bases of computer systems. Several computer systems have been used since the inauguration of RMIS (Regional Monitoring IBM System) in 1956. In 1971, the EMA (Environmental Monitoring Analysis) $)^{(b)}$ computer system was established. The EMA system was later replaced by HEDS (ㅂanford Environmental Data System) and PDMS (Project and Data Management System). The HEIS

(a) Locations manuals and procedures manuals are reviewed annually and revised as necessary.

(b) A definition of the acronym EMA, "Environmental Monitoring Analyses," apparently was first recorded in 1977 in a technical procedures document prepared for the Energy Research and Development Administration (PNNL, 1977). 
computer system (Hanford Environmental Information System) is now in use for all environmental data collected by PNNL for the Hanford Site. All current and historical data were transferred into each new data management system when it was put unto use.

\subsubsection{Location Identifying EMA Numbers}

Sample location identifying numbers, i.e., EMA numbers ${ }^{(a)}$, were established in 1971 for the original EMA computer system and were used to identify specific sampling locations where soil and other types of samples were collected (Blummer and Corley 1971). An apparent original EMA number logbook was found in storage box \#134924(b). The logbook identified EMA numbers for soil sampling locations in use until 1989 when data were transferred to the HEIS computer system. Although undated, the earliest handwritten entries in the logbook must have been prepared in the early 1970s (probably 1971) because soil samples were identified with EMA numbers for "soil sample 0-1 in." and "soil sample 1-2 in." Samples from each of these 1-inch-deep layers of soil were collected for the routine environmental monitoring program only in 1971 and 1972.

An original carbon copy of an "Environmental Monitoring Trip Log" was found in an historical file. The trip log (a.k.a. trip sheet) listed the EMA numbers and associated literal names for locations of the first soil samples collected in 1971 for the routine environmental monitoring program. These numbers were the same as those listed in the EMA number logbook. The trip log was dated 4-6-72, but the sample collection dates were recorded as 9-29-71, 9-30-71, and 10-1-71. An "Environmental Monitoring Analysis Report" (i.e., computerized result report) from U.S. Testing Co., Inc. dated 5-26-72 reported plutonium-238 and plutonium-239,240 data for soil samples with the same EMA numbers as indicated on the trip log dated 4-6-72. The "Soil, Sediment and Vegetation" logbook of handwritten analytical results contained data reported from 1971 to 1989 . The EMA numbers for soil samples collected from 1971 through 1992 were the same as for those found in the records listed above, and they did not change over the years. Additional EMA numbers were assigned as new locations were established, but the same EMA number was not assigned to more than one location. After 1992, the HEIS computer system and its unique numbering system was put into use to maintain the identity of sampling locations.

In summary, EMA numbers were assigned to sampling locations in order to process information in the EMA computer system and subsequent systems. Specific EMA numbers for soil sampling locations were first assigned in 1971. Records show that the EMA numbers assigned to soil sampling locations established in 1971 and later years remained unchanged until a different computer system was put into use in 1992 to maintain the identity of sampling locations.

(a) EMA Numbers were specific for location, media, and sample type.

(b) Retrieved from Hanford Sitewide Records Services, U.S. Department of Energy, Richland, Washington. 


\subsubsection{Locations Manuals}

A locations manual for environmental sampling was prepared in 1978 and updated in 1979 to include soil sampling locations (Blummer 1979). The 1979 locations manual contained maps, photographs, and general descriptions of all soil sampling locations in use at the time. The 1979 locations manual, and subsequent revisions published in 1983 (PNNL 1983) and in 1991 (PNNL 1991), provided formalized documentation of where samples were to be collected for the routine environmental monitoring program. A review of the three locations manuals showed the following breakdown in the number of onsite and offsite soil sampling locations:

- 1979,11 onsite locations and 10 offsite locations

\begin{tabular}{ll}
\multicolumn{1}{c}{ Onsite } & \multicolumn{1}{c}{ Offsite } \\
Wahluke Slope No. 2 & Benton City \\
Yakima Barricade & Sunnyside \\
East of 200 West Area & Harris Farm \\
200 ENC & Byers Landing \\
200 ESE & Sagemoor \\
Hanford Townsite & Fir Road \\
SE FFTF & Taylor Flats No. 1 \\
NE FFTF & Taylor Flats No. 2 \\
Wye Barricade & Ringold \\
Prosser Barricade & Berg Ranch \\
ALE &
\end{tabular}

- 1983,11 original plus 12 additional onsite locations (23 total), and 9 of the original offsite locations (Taylor Flats No. 1 deleted)

- 1991, the same 23 onsite locations and 9 offsite locations listed in 1983 plus 7 additional offsite locations (total 16).

Sampling was discontinued at the Taylor Flats \#1 location when the access road was blocked by landslides. Thus, the original 20 soil sampling locations listed in the 1979 locations manual, minus Taylor Flats \#1, were also listed in the later manuals and are considered long-term locations as discussed in Section 3.0, "Evaluation of Long-Term Sampling Locations."

Descriptions given in the locations manuals were essentially identical with the following two exceptions. According to the 1991 manual, the specific sampling site at the Wye Barricade was moved several hundred yards from the west side of Route $4 \mathrm{~S}$ to the east side of Route 4S. The move apparently was made in the late-1980s when the road was relocated and the guard house was replaced. The assigned EMA number remained the same. 
The literal name and EMA number for the Byers Landing sampling location have not changed since 1971. However, the location descriptions and photographs provided in the 1979 and 1983 locations manuals differed from those given in the 1991 locations manual. The earlier versions stated that the specific sampling site was "...located to the east, across the road from the air sampler." The 1991 version stated, "Continue east across the canal (from the air sampler) for 0.1 mile. Samples are collected from an undisturbed area on the left (north) side of the road." The location was changed because the original field was plowed and planted with alfalfa. According to a comment in the data base, the first sample was collected at this new location in June 1992.

Photographs of soil sampling locations shown in the 1979 locations manual were noted as being similar to those appearing in later versions except for the Wye Barricade and Byers Landing. Box \#134924 retrieved from storage contained copies of the original photographs used in the 1979 locations manual. The historical photographs were used to verify the current soil sampling locations (see Section 3.0, "Evaluation of Soil Sampling Locations").

Many of the soil sampling locations were originally associated with "control plots." A PNNL monthly report prepared in $1972^{(a)}$ contained the following statement:

"The new Environmental Monitoring sites are now being posted. This will standardize the identification signs of all control plots, soil sample and vegetation plots and shoreline survey sites. Control plot signs only will be numbered."

These same identification signs are still present at onsite sampling locations and three perimeter offsite locations as noted in the locations manuals. The signs apparently were never placed on private land, and the three perimeter locations were associated with property originally under government control. The signs have a notation at the bottom "DUN Signs-1-72." Douglas United Nuclear, Inc. (DUN) apparently operated the sign shop at the Hanford Site in 1972.

\subsubsection{Master Schedules and Annual Environmental Reports}

Master schedules have been published in one form or another since environmental monitoring began at Hanford in the mid-1940s. Master schedules published annually in the early 1970s (and later) listed the sample types (including soil), locations, and corresponding EMA numbers of samples to be collected. Annual environmental reports ${ }^{(b)}$ have been published since 1957 to summarize and discuss results from environmental monitoring activities at Hanford. "Environmental Status Reports" emphasized data for locations on the Hanford Site (so-called onsite reports) and were published from 1965 through 1983. "Environmental Surveillance Reports" emphasized data for locations off of the Hanford Site (so-called offsite reports) and were published from 1957 to the present.

(a) PNNL Monthly Report - January 1972, M. W. Leale to J. P. Corley, January 25, 1972, archives of historical records.

(b) All annual environmental reports prepared for the Hanford Site to 1986 are listed in Price (1988). 
A review of master schedules showed that EMA numbers and the general literal names of locations have remained the same over the years, with one exception. The "200 East Hill" sampling location apparently was established in 1971 at Control Plot (CP) \#61, where a telephone line crossed Highway 4S near the bottom of the hill east of the 200 East Area $^{(a)}$. However, the literal name given in the master schedule for calendar year 1978 was the "200 East Hill Air Sampling Station." This indicated that the soil sampling site was relocated to the top of the 200 East hill near the air sampling station and CP \#15. However, the annual Environmental Status. Reports for the Hanford Site reported data for "200 East Hill" in 1971 through 1973 and for "CP \#61" in 1974 and 1975. Maps in the annual Environmental Surveillance Reports for 1971 through 1975 showed the general location of soil sampling to be near CP \#61. In 1977 , the literal "200 East Hill" was again used, and the map location appeared to be near CP \#15 at the top of the 200 East hill (the 1976 report did not show data for all soil sampling locations). In 1983, the literal name was changed to "200 ESE" (same as the name change for the air sampling station), but the map location near CP \#15 remained the same. Thus, the location for collecting soil samples from near the southeast corner of the 200 East Area was probably moved in 1976 or 1977 from the bottom of the 200 East hill to the top of the hill, about 2.25 miles closer to the Plutonium Uranium Extraction (PUREX) Plant stack than the original location.

The literal name and the EMA number of the Benton City sampling location have not changed since 1971; however, available records show that the specific sampling location may have been changed.

A hand-drawn map accompanying a trip log recording the collection of special samples in 1970 showed a Benton City sampling location at the 614 Building air sampling station near the Public Utility District (PUD) electrical substation off Horn Road, north of Benton City proper. However, all locations manuals described the Benton City location as 4.8 miles south of Highway 240 on Horn Road. This location is near the old southern boundary of the Hanford Site and several miles north of Benton City. Annual reports from 1971 through 1982 showed map locations indicating the sampling location to be on the outskirts of Benton City. The 1983 report showed the map location as described in the 1979 and subsequent locations manuals. Thus, the Benton City soil sampling location may have been relocated several miles north of the original location, toward the Hanford Site. The year of change was not recorded, but four new offsite sampling locations were established in 1977, and "Benton City" was again sampled after two years of no sampling. Perhaps the sampling site for "Benton City" was changed in 1977 to the current location, and samples collected in 1971 through 1974 were collected near the PUD electrical substation.

\subsubsection{Summary of Information on Sampling Locations}

Literal names, EMA numbers, and locations for all long-term soil sampling sites listed in the locations manuals, master schedules, annual reports, and the results logbook appear to have remained the same since 1971 with the following exceptions. The literal names of several soil sampling locations have incurred minor name changes over the years. These a.k.a. names are noted in Section 3.0, "Evaluation of Soil Sampling Locations." Four sampling locations apparently were physically relocated. The Wye Barricade location was relocated across the road from the original site in the late-1980s. The Byers Landing location

(a) The location was shown on an environmental monitoring map dated May 1973. However, there is no telephone line crossing at the bottom of the 200 East hill at the present time. 
was moved about 0.1 mile east of the original site in time for the 1992 sampling. The 200 ESE location was moved about 2.25 miles closer to the PUREX Plant stack in 1976 or 1977 . The Benton City location may have been relocated several miles closer to the Hanford Site in the mid-1970s.

\subsection{Sample Collection Procedures}

The first recorded description of a procedure used to collect soil samples was described at a technical symposium in 1971 (Corley et al. 1971):

"Initial sampling was done with a flat-bottomed scoop approximately 18 by 12 inches. An attempt was made to take only the top one-half inch of soil. Subsequent sampling has been done with a closed-top sampler to minimize variation in sample depth. An ordinary cellulose tape container gives a neat, sharp-edged, reproducible cut in our desert soils, $9 \mathrm{~cm}$ in diameter by $1.6 \mathrm{~cm}$ deep, provided no large gravels are present."

Soil sampling for the routine environmental monitoring program was also described in the Technical Procedures Document (PNNL 1977). The following description of soil sampling was noted in the section on Sampling Methods under the heading Soil and Vegetation:

"Surface soil samples are collected from selected areas of the Hanford Site and vicinity by using a 'cookie cutter' sampler approximately $5 \mathrm{~cm}$ in diameter and $25 \mathrm{~cm}$ in depth. Generally 5 spots are sampled within the area which have a minimum of vegetation."

This record is believed to be inaccurate. Perhaps the $5 \mathrm{~cm}$ was really the radius and the $25 \mathrm{~cm}$ depth should have read $2.5 \mathrm{~cm}$ (i.e., $10 \mathrm{~cm}$ in diameter and $2.5 \mathrm{~cm}$ deep as noted below). The term "cookie cutter" was accurate, however, because even today the soil sampling tool is referred to as a "cookie cutter," in obvious reference to the original cellulose tape container noted by Corley et al. in 1971.

\subsubsection{Annual Environmental Surveillance Reports and Special Reports}

The onsite annual environmental reports ${ }^{(2)}$ for 1971 (Bramson and Corley 1972) and 1972 (Bramson and Corley 1973) referred only to "...samples of the top two inches of soil...." However, the data tables showed that the top two inches consisted of two separate, one-inch-deep samples. The 1973 onsite report (Nees and Corley 1975) repeated the "...samples of the top two inches of soil...." statement, but the accompanying data table recorded only a single result for most locations. The logbook of handwritten results and the computer data base file recorded only one result for 1973 and listed the respective EMA

(a) The onsite annual environmental report published from 1971 through 1983 was entitled Environmental Status of the Hanford Site for CY-19xx. The offsite report was entitled Environmental Surveillance at Hanford for CY-19xx. The onsite report was discontinued in 1983, and all data were combined into a single report renamed Environmental Monitoring at Hanford for $19 x x$. 
number associated with the $0-1$ inch soil layer. Profile samples, to a depth of 12 inches, were also collected at three locations and reported in the 1973 annual report. In all likelihood, the statement about the top 2 inches of soil was a typographical error in the 1973 report because the wording was identical to the 1972 report. The 1974 report (Fix 1975), and reports for subsequent years, specifically stated that samples were collected from the top inch of surface soil. The annual report for 1974 was the first annual report to provide details on sampling:

"Each soil sample represents the composite of five 'plugs' of soil from an approximate $10 \mathrm{~m}^{2}$ area. Each plug was approximately 2.5 centimeters ( 1 inch) in depth and 10 centimeters ( 4 inches) in diameter."

Later, the sampling procedure was described in a special report reviewing results from the first 6 years of soil sampling for the routine environmental monitoring program (Miller et al. 1977):

"During the years 1971 through 1976, 136 soil and vegetation samples were collected from the Hanford environs. ...Each soil sample analyzed was a composite of 5 'plugs' of soil collected from an area approximately 10 meters square. Each plug was about 2.5 centimeters in depth and 10 centimeters in diameter."

\subsubsection{Procedures Manuals}

The first procedures manual may have been prepared in the mid- or late-1970s similar to the locations manual, but a copy was not located for this review. The earliest written procedure for soil sampling found in the historical record was a reference dated to 1984 (in Price et al. 1986). The selection of a specific sampling site was described as:

"Select five spots at least 10 paces apart within the desired sampling area which have a minimum of surface vegetation. If the sample site comes under cultivation or is otherwise disturbed, the EM supervisor should be notified so that an alternate site may be selected. Avoid sampling spots which are wind eroded, rocky, or disturbed significantly by animals."

A PNNL memo written in $1971^{(a)}$ regarding the collection of mud, soil, and vegetation samples for preoperational sampling at the construction site of the 331 Building stated:

"For soil samples, try to find undisturbed soil as close as possible to indicated spots (on attached map)."

Apparently, the objective has always been to collect soil samples from relatively undisturbed areas.

(a) PNNL Memo, J. P. Corley to W. C. Horton, Pre-Operational Sampling - 331 Building, February 16, 1971. 


\subsubsection{Summary of Information on Sample Collection Procedures}

The historical records show that soil sampling for the routine environmental monitoring program has not changed significantly since 1971 . Five plugs of soil, $2.5 \mathrm{~cm}$ deep and $10 \mathrm{~cm}$ in diameter, were collected at each sampling location within a relatively small area, placed into a common container (i.e., composited), labeled, and delivered to the analytical laboratory for radiochemical analysis. A minimum amount of vegetation was included with the soil sample. Since 1984, and probably since 1971, soil samples were to be collected from relatively undisturbed areas.

\subsection{Analytical Procedures}

One way to discover if analytical procedures have changed significantly since 1971 is to evaluate the usage of isotope identifying codes, i.e., numerical designators established by PNNL and originally used by U.S. Testing Co., Inc. to report analytical results for specific isotopes. The original 1971 version of the EMA Program Users Manual, Section V, "Isotope Codes," listed the following codes (in addition to others): 121 for strontium-90, 024 for cesium-137, 103 for plutonium-239 and 104 for uranium (Blummer and Corley 1971). A revised page in the manual dated July 1, 1974, indicated the addition of the isotope code 102 for plutonium-238. However, plutonium-238 analytical results were recorded in the logbook of handwritten results and the computer data base beginning in 1971. In a 1977 revision of the EMA Program User's Manual (Blummer and Fix 1977), Section V, "Isotope Codes," noted the following code changes: 100 for plutonium-239,240 and 103 for plutonium. Thus, isotope code 103 in the historical record referred to both plutonium-239 and plutonium (or total plutonium) as noted below. The use of different isotope codes for plutonium was probably associated with the different analytical techniques used to detect plutonium in soil samples.

Although not well documented, it appears that some of the original plutonium data for soil samples analyzed by U.S. Testing Co., Inc. (e.g., as reported by Corley et al. 1971) were obtained by extracting and isolating the plutonium from the sample, electroplating it onto a stainless steel disc, and then exposing the disc to photographic film. The number of alpha tracks recorded on the film (produced by all isotopes of plutonium present) were counted by visual inspection with a microscope, converted to picocuries per unit of sample ( $\mathrm{pCi} / \mathrm{g}$ ), and reported ${ }^{(a)}$. Such samples would have been reported under isotope code 103 for plutonium or plutonium-239. This was the same as the routine procedure used by U.S. Testing Co., Inc. for bioassay samples that were reported as total plutonium. Some of the early plutonium soil analyses (also reported in Corley et al. 1971) were analyzed in laboratories operated by PNNL and utilized a similar extracting and isolating technique. However, the resulting solution was evaporated onto a stainless steel disc and counted electronically with a silicon surface-barrier detector to determine the isotopes of

(a) Each alpha track was created by one disintegration of a plutonium atom. The number of disintegrations per minute $(\mathrm{d} / \mathrm{m})$ of film exposure was calculated and related to the weight $(\mathrm{g})$ of the sample. The calculated $\mathrm{d} / \mathrm{m}$ per gram was converted to picocuries per gram $(2.22 \mathrm{~d} / \mathrm{m} / \mathrm{g}=1 \mathrm{pCi} / \mathrm{g})$ and reported as the result. 
plutonium separately (so called "alpha spectrometry"). These results were reported under isotope codes 102 for plutonium-238 and 100 for plutonium-239,240. By 1972, U.S. Testing Co., Inc. was also analyzing certain samples by alpha spectrometry ${ }^{(a)}$. Counting uncertainties (error terms) consisting of \pm two standard deviations of the count rate were not routinely reported by U.S. Testing Co., Inc. until 1977. Beginning in 1984, both the counting uncertainty and \pm two times the total propagated uncertainty (for the entire analytical procedure) were reported by the analytical laboratory as a part of each result.

The annual environmental surveillance report for 1971 (Bramson and Corley 1972) recorded the analytical procedures used by U.S. Testing Co., Inc. at the time. Gamma scans to detect cesium-137 and other gamma-emitting radionuclides were performed with a lithium-drifted germanium (GeLi) detector. Strontium-90 and isotopes of plutonium were analyzed using chemical separation and specific analyses. Air and water samples were analyzed for total plutonium by the photographic film alpha track method. Solid foodstuffs, vegetation, and soil were analyzed for plutonium isotopes using alpha spectrometry. The film-track results were reported under isotope code 103 for (total) plutonium, and the alpha spectrometry results were reported under the isotope codes 102 for plutonium-238 and 100 for plutonium-239,240. Curiously, the PNNL computer data base shows results recorded in 1971 and 1972 (for both the 0-1 inch and 1-2 inch soil layers) for isotope codes 100 (plutonium-239,240) and 103 (plutonium). In most cases, the results for isotope code 100 are a three-decimal-place rounding of the results for isotope code 103 . The sampling dates for each entry are the same. Beginning in 1973, the only isotope codes listed in the computer data base for routine soil samples are 100 for plutonium-239,240 and 102 for plutonium-238. The reason for the double entries is unknown, but it is improbable that the samples collected in 1971 and 1972 were analyzed twice. It is more likely that the addition of isotope code 103 to the data base required the transfer of data from one isotope code to another, and the original data were retained. Analytical results for routine soil samples reported in the 1971 annual report included plutonium-238 and plutonium (assumed to be plutonium-239,240). However, the samples must have been analyzed by alpha spectrometry because plutonium- 238 could only be detected by that method.

\subsubsection{Summary of Information on Analytical Procedures}

The isotope identifying codes used to report strontium-90 or cesium-137 have not changed since 1971 . However, plutonium data for soil samples analyzed before 1972 by U.S. Testing Co., Inc. were probably the result of a photographic film-alpha track procedure and were understood to represent total plutonium. Results were reported under isotope code 103. Soil samples analyzed in 1972 (i.e., samples collected in both 1971 and 1972) and in later years were analyzed by alpha spectrometry, i.e., a silicon surface-barrier detector system capable of separately identifying plutonium-238 and plutonium-239,240 (the technique, as today, did not differentiate between the isotopes plutonium-239 and plutonium-240). Results were reported under isotope code 100. The annual environmental surveillance report for 1971 (Bramson and Corley 1972) recorded the analytical procedures used by U.S. Testing Co., Inc. at the time and stated that

(a) The first routine soil samples collected for the environmental monitoring program (i.e., samples not collected for a special purpose) were obtained in September and October 1971, but apparently were not submitted to U.S. Testing Co., Inc. for analysis until April 1972. 
soil samples were analyzed by alpha spectrometry. Thus, all results from the analyses of routine soil samples reported in annual reports since 1971 were apparently determined by alpha spectrometry and included plutonium-238 and plutonium-239,240.

\subsection{Previously Unreported Results}

An attempt was made in 1987 to review the analytical results for all historical soil samples collected for the routine environmental monitoring program (Price 1988). Some new information was discovered during the current review. Before 1970 , the few special soil samples collected were usually analyzed only for total (gross) beta, total (gross) alpha, strontium ( 89 and 90 isotopes), and a gamma scan was run, primarily for ruthenium-106 and cesium- 137 .

A spread of plutonium contamination to the offsite environment at the U.S. Atomic Energy Commission's (AEC) Rocky Flats Plant was discovered in the late 1960s, which led to concern and speculation about contamination in the environs at all AEC facilities that handled plutonium. An AEC letter ${ }^{(a)}$ from Washington D.C. Headquarters to the Richland and Savannah River Operations Offices in late 1969 noted the situation at Rocky Flats and asked "...do you sample and measure the plutonium content of soil at your site...?" The answer was "no," and the inquiry provided the initiative to collect soil samples from the Hanford Site and vicinity for plutonium analyses. Soil samples were first collected in February 1970 from both onsite and offsite locations. Additional samples were collected later in 1970 and in 1971. Results were reported by Corley et al. (1971) at a scientific symposium held in Los Alamos, New Mexico. Soil samples were collected on a routine basis beginning in 1971, and results have been published in annual environmental reports from 1971 through 1994. Since 1989, the need for collecting additional soil samples has been evaluated each year.

Results for samples not previously reported in annual or special reports for the years 1970 through 1972 are listed in Appendix A. No other records of unreported results were located in the historical files during this review.

\subsubsection{Summary of Unreported Results Listed in Appendix A}

Unreported results were found in historical records for the locations listed below. None of the results was noted to be extraordinary.

1970

1. Two samples were collected from an area northeast of the Jersey Nuclear uranium fuel manufacturing plant (currently Siemens Power Corp.). Samples were analyzed by U.S. Testing Co., Inc.

(a) AEC Letter, from F. P. Baranowski (Washington D.C.) to D. G. Williams (Richland Operations Office), Soil Contamination by Reactor Products, December 19, 1969. 
2. Four offsite samples from the general area of Byers Landing were collected jointly with the AEC Division of Compliance. A composite background sample was collected also. Analyses were performed by an AEC laboratory at the Idaho National Engineering Laboratory, Idaho Falls, Idaho.

1971

1. Ten samples were collected from four locations at the construction site of the Fast Flux Test Facility (FFTF) as part of a pre-operational survey. Samples were analyzed by U.S. Testing Co., Inc.

2. Five samples were collected as part of a pre-operational survey at the 331 Building. Samples were analyzed by U.S. Testing Co., Inc.

3. A composite of four samples collected from the Wahluke Slope across the River from the 100-K Area and 100-N Area was analyzed by U.S. Testing Co., Inc.

4. Five soil samples, from three offsite and two onsite locations, were analyzed by U.S. Testing Co., Inc.

1972

1. Eleven samples were collected from five offsite locations, five onsite locations, and Locke Island. Samples were analyzed by U.S. Testing Co., Inc.

2. Three soil samples and one mud sample were collected from the vicinity of Honey Hill Pond (a.k.a. West Lake). Samples were analyzed by U.S. Testing Co., Inc.

3. Samples collected from three onsite locations near 200 East Area were analyzed by U.S. Testing Co., Inc.

\subsection{Summary of Reported Results}

Results from the analyses of soil samples collected routinely each year were reported in annual reports. In addition, three reviews and summaries have been prepared over the years (Miller et al. 1977, Price 1988, Poston et al. 1995). However, for completeness, Appendix B lists data for soil samples collected at the 20 long-term sampling locations and two supplemental locations. Supplemental locations in proximity to other long-term sampling sites are included to enhance the long-term record. The results shown for each sampling location represent all data in the PNNL computer data base for strontium-90, cesium-137, plutonium, plutonium-238, and plutonium-239,240 for 1971 through 1994 (the last year of sampling).

The supplemental locations are "FFTF Control Plot 62" and "ERC." The FFTF Control Plot 62 supplements both the NE FFTF and SE FFTF sampling locations. The FFTF Control Plot 62 was sampled from 1971 through 1974 and was located between the other FFTF locations. The NE FFTF and SE FFTF locations were sampled from 1975 through 1994. ERC is located several hundred yards from the ALE sampling site. ERC was sampled from 1971 through 1974; ALE was sampled from 1975 through 1993. 


\subsection{Conclusions for the Review of Historical Records}

Environmental monitoring program historical files and annual reports were reviewed for information and documentation on the following issues:

- Have soil sampling locations changed significantly over the years?

Literal names, EMA numbers, and locations for all soil sampling sites listed in the locations manuals, master schedules, annual reports, and the results logbook appear to have remained the same since 1971 , or the year the location was established, with the following exceptions. The literal names of several soil sampling locations have incurred minor name changes over the years. These a.k.a. names are noted in Section 3.0, "Evaluation of Soil Sampling Locations." Four sampling locations apparently were physically relocated. The Wye Barricade location was relocated across the road from the original site in the late-1980s. The Byers Landing location was moved about 0.1 mile east of the original site in 1992. The 200 ESE location was moved about 2.25 miles closer to the PUREX Plant stack in 1976 or 1977. The Benton City location was relocated several miles closer to the Hanford Site in the mid1970s.

- Have soil sampling procedures changed significantly over the years?

Soil sampling procedures have not changed significantly since 1971 . Five plugs of soil, $2.5 \mathrm{~cm}$ deep and $10 \mathrm{~cm}$ in diameter, were collected at each sampling location, placed into a common container (i.e., composited), labeled, and delivered to the analytical laboratory for radiochemical analysis. A minimum amount of vegetation was included with the soil sample. Records show that since 1984, and probably since 1971, soil samples have been collected from relatively undisturbed fields.

- Have significant changes occurred over the years in analytical procedures used to detect plutonium in soil samples or to report data?

The isotope code identifiers used to report strontium-90, cesium-137, or uranium have not changed since 1971. However, plutonium data for soil samples analyzed before 1972 by U.S. Testing Co., Inc. were analyzed by a photographic film-track method and were understood to represent total plutonium. Results were reported under isotope code 103. Routine soil samples analyzed in 1972 (i.e., samples collected in both 1971 and 1972) and later years were processed using a silicon surface-barrier detector system capable of separately identifying the isotopes plutonium- 238 and plutonium- 239,240 (the technique, even as used today, does not differentiate between the isotopes plutonium-239 and plutonium-240). Results were reported under isotope code 100. All results from the analyses of routine soil samples reported in the annual reports since 1971 were determined by alpha spectrometry and included the isotopes of plutonium-238 and plutonium-239,240. 
- Have all significant results for plutonium and other important long-lived radionuclides detected in soil samples been reported?

Previously unreported results from soil sampling for 1970, 1971, and 1972 were located in archived historical records and are listed in Appendix A. None of the results are considered extraordinary. 


\subsection{Evaluation of Long-Term Sampling Locations}

Records reviewed for this report (see Section 2.0, "Historical Records") revealed that the locations of 16 of 21 soil sampling sites listed in the original 1979 locations manual (Blummer 1979) are identical to those in use today. The Taylor Flats \#1 location was sampled only from 1978 through 1982 when the access road was closed due to a landslide. Therefore, 20 of the 21 locations are discussed in this section. Of those 20 sampling locations, specific sampling sites at the Wye Barricade and Byers Landing were relocated a short distance from their original locations. In addition, two locations, $200 \mathrm{ESE}$ and Benton City (see discussion under Section 2.2, "Sampling Locations"), apparently were moved a short distance before the 1979 locations manual was published. Previous reviews of soil sampling results (Price 1988; Poston et al. 1995) revealed that 9 of the 21 sampling locations listed in the 1979 locations manual were established in 1971, the first year of sampling, and that most of the 21 locations were sampled nearly continuously from the time they were established until 1994, the last year of sampling. Thus, much of the data for soil samples recorded in the PNNL data base are for 20 of the 21 sampling locations listed in the 1979 locations manual. Together, these long-term sampling locations provide a continuous record of radionuclides measured in soil collected from the Hanford environs. Figure 3.1 shows the locations of the 20 long-term sampling locations. Appendix B lists analytical results for the 20 long-term sampling locations and two supplemental locations. The results shown for each sampling location represent all data in the PNNL computer data base for strontium-90, cesium-137, plutonium, plutonium-238, and plutonium-239,240 for the years 1971 through 1994, the last year of sampling.

Over the years, soil samples usually have been collected from relatively undisturbed areas or areas where activities such as farming did not interfere with the sample representing the site, but formal evaluations and descriptions of the sites have not been documented. This section provides such documentation for each of the 20 long-term sampling locations.

\subsection{Evaluation of Soil Sampling Locations}

The 20 long-term soil sampling locations listed in the 1979 locations manual were evaluated. Each sampling location was visited using the directions given in the original locations manual and in subsequent revisions (PNNL 1983; PNNL 1991). The sites were compared to the location descriptions provided in the manuals, and any discrepancies were noted. Photographs of the general locations given in the manuals were also compared to existing conditions. Information on current land use, a site description, and a new photograph were prepared for each site.

\subsubsection{Current Land Use}

Current land use was noted and described at each long-term onsite and offsite sampling location. Where possible, current land use was compared with the perceived historical use or original condition of the land at the time the sampling site was established. Historical use was estimated by evaluating the 


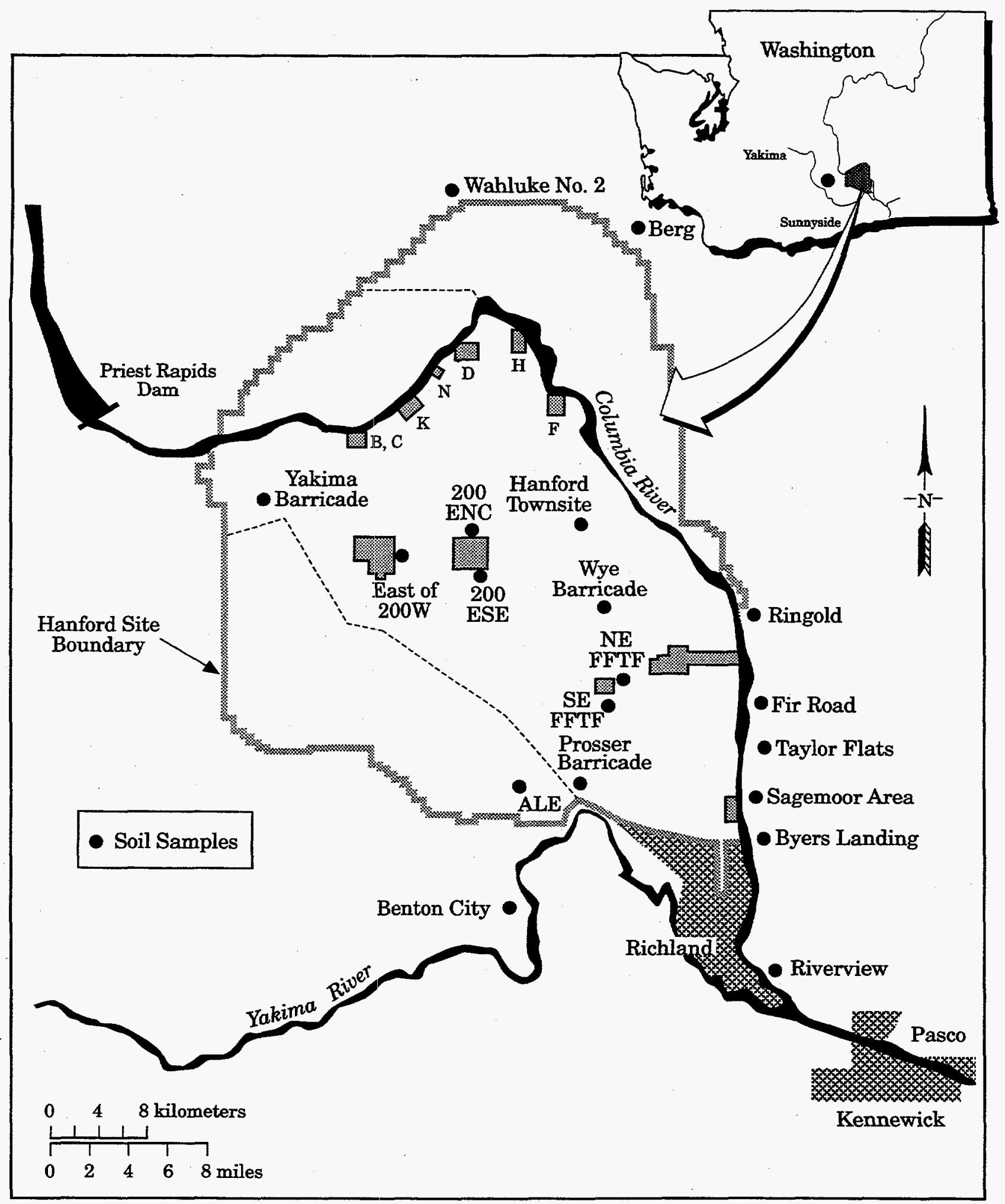

S9402063.92aa 
degree of soil surface disturbance, the amount of use by livestock, and the type of vegetation present. A close-up photograph of the soil surface was taken where a definite soil crust of lichens and mosses was observed. The absence of manure and the presence of a soil crust were interpreted as indications of the absence of livestock use or other surface disturbances for a relatively long period of time. The presence of mature shrubs was interpreted as indicating the absence of intensive agricultural use, such as plowing, for a relatively long period of time.

\subsubsection{Sampling Site Descriptions}

A list of plant species growing in the vicinity of the sampling site was prepared for each location. The list was not comprehensive, but rather indicative of the dominant species present. Other site conditions were noted such as topography, the degree (percent) of plant canopy cover over the land surface, indications of current or past livestock use, evidence of recent wildfire, and other noteworthy conditions. Historically, soil samples have been collected from areas between shrubs. When shrubs were present at the sampling site, the percent plant cover was estimated for areas between shrubs. When shrubs were absent, the percent plant cover was estimated for the site in general. The percent cover of plant shoots within a 0.5 meter by 1.0 meter plot frame (divided into 50 equal squares for convenience of estimating) was recorded. The plot frame was used to estimate plant cover representing two extreme conditions at each soil sampling location, i.e., areas with the greatest plant cover and areas of least plant cover. Photographs were taken of the plot frame in each position.

\subsection{Field Records for Each Soil Sampling Location}

Eleven onsite and nine offsite long-term soil sampling locations listed in locations manuals and used almost continuously use since 1971 , or the year of establishment, were visited from late June to early July 1996. Transcribed field records for each location are summarized in the following sections. Field records included a general description of each site location, a general description of the site, a description of current land use, and a list of dominant plant species. A summary of the sampling history for each site is also provided. The EMA number of the location and the Global Positioning System (GPS) reading obtained at each site on September 16 and 17, 1996, are included as part of the field records. The GPS data are also tabulated separately in Appendix C.

The name used for each sampling site is that given in the first (1979) version of the locations manual. Names used in later versions of the locations manual and other documents (e.g., annual reports) are noted as a.k.a. The order in which the locations are listed is the order given in the original locations manual.

\subsubsection{Onsite Sampling Locations}

1. Wahluke Slope No. 2 (a.k.a. Wahluke Slope)

Grant County, EMA Location No. 6007

GPS: $X$ Position $=565674 ; \mathrm{Y}$ Position $=156293$ 
Until publication of the 1991 locations manual, this site was listed as an onsite location. The site is located near the intersection of State Highway 24 and Mattawa Road just outside the northwestern boundary of the Hanford Site. The site is on private land adjacent to the Wahluke Slope air sampling station and is marked with an "Environmental Sampling Location" sign. The specific soil sampling site is in an open field approximately 50 feet south of the sign. The name Wahluke No. 1 was never used, but a location called Wahluke Slope Opposite 100-N was sampled from 1971 through 1974.

General Site Description The sampling site is located within a sagebrush-hopsage/cheatgrass habitat near an irrigated field. The general topography is flat with micro-scale mounding creating ridges and swales. Large sagebrush plants are present with no evidence of recent wildfire. The soil is probably sandy loam. The soil surface shows a well developed crust of mosses and lichens.

Current Land Use The site has been used for livestock grazing in the past, but it is currently idle. The land probably has never been plowed as evidenced by the presence of large shrubs and ridge and swale micro-topography. The present condition of the site is probably similar to that in 1971 when the site was established.

Sampling History Samples were collected from the 0-1 inch layer of surface soil at this site each year from 1971 through 1993, except 1991 and 1992. In 1971 and 1972, samples were also collected from the 1-2 inch layer of soil.

\section{Predominant Plant Species Present}

Shrubs: $\quad$ big sagebrush (Artemisia tridentata)

spiny hopsage (Grayia spinosa)

green rabbitbrush (Chrysothamnus viscidiflorus)

Forbs: Jim Hill's tumblemustard (Sisymbrium altissimum)

Grasses: $\quad$ cheatgrass (Bromus tectorum)

Sandberg's bluegrass (Poa sandbergii)

Plant Cover Between Shrubs (0.5 $\mathrm{m}^{2}$ Plot)

Greatest plant cover (ridges): $\quad 40 \%-$ - cheatgrass

$20 \%$-- Sandberg's bluegrass

$40 \%$-- exposed ground with moss and lichen crust

Least plant cover (swales): $\quad 30 \%$-- Sandberg's bluegrass

$70 \%$-- exposed ground with moss and lichen crust

Trace amount of cheatgrass present 


\section{Yakima Barricade}

Benton County, EMA Location No. 6016

GPS: $\mathrm{X}$ Position $=559280 ; \mathrm{Y}$ Position $=138657$

The site is located adjacent (just north) of the Yakima Barricade entrance to the Hanford Site at the intersection of Hanford Highway Route 11A and State Highway 240. The site is marked with an "Environmental Sampling Location" sign. The specific soil sampling site is about 50 feet northeast of the air sampling station near the sign.

General Site Description The site is located in a sagebrush-hopsage/cheatgrass habitat. The general topography is level with some micro-scale mounding associated with shrubs. The soil is probably loamy sand. There is no sign of recent wildfire, and the presence of many large shrubs indicates that the site has not burned after 1971. Small rodent diggings are present. The soil surface in open areas is partially crusted with mosses and lichens and shows some cracking.

Current Land Use The site is idle and has not been used for agricultural production since the Hanford Site was established in the 1940s: The land probably has never been plowed because of the soil mounding associated with shrubs. The present condition of the site is probably similar to that in 1971 when sampling began.

Sampling History Samples were collected from the 0-1 inch layer of surface soil at this site each year from 1971 through 1993, except 1986, 1990, and 1992. In 1971 and 1972, samples were also collected from the 1-2 inch layer of soil.

\section{Predominant Plant Species Present}

Shrubs: $\quad$ big sagebrush (Artemisia tridentata) spiny hopsage (Grayia spinosa)

Grasses: $\quad$ cheatgrass (Bromus tectorum) bottlebrush squirreltail (Sitanion hystrix)

Sandberg's bluegrass (Poa sandbergii)

\section{Plant Cover Between Shrubs (0.5 $\mathrm{m}^{2}$ Plot)}

Greatest plant cover: $\quad 100 \%$-- cheatgrass

Least plant cover: $\quad 5 \%$-- cheatgrass

$30 \%$-- exposed ground with moss and lichen crust

$65 \%$-- bare ground 


\section{East of 200 West Area (a.k.a. E of 200-W Gate)}

Benton County, EMA Location No. 6276

GPS: $\mathrm{X}$ Position $=568447$; Position $=136137$

The site is located across the road (Hanford Highway Route 3) and just north of the east entrance to the 200-West Area (old 200 West main gate). The site is marked with an "Environmental Sampling Location" sign. The specific soil sampling site is a few feet east of the sign.

General Site Description The sampling site is located within a sagebrush/cheatgrass habitat. The general topography is flat. Mature sagebrush plants are present with no evidence of recent wildfire. The soil is probably sand. The soil surface in open areas is only slightly crusted with mosses and lichens.

Current Land Use The site is idle and has not been used for agricultural production since the Hanford Site was established. The land probably has never been plowed because it is only marginally suitable for dryland farming, and irrigation water was not available. The area may have been disturbed during construction activities at the 200-West Area. The present condition of the site is probably similar to that in 1975 when sampling began.

Sampling History Samples were collected from the 0-1 inch layer of surface soil at this site each year from 1975 through 1994, except 1992. As part of a special study, samples were collected in one-inch increments from the surface to a depth of 12 inches (Price 1991).

\section{Predominant Plant Species Present}

Shrubs: $\quad$ big sagebrush (Artemisia tridentata)

green rabbitbrush (Chrysothamnus viscidiflorus)

Forbs: $\quad$ Russian thistle (Salsola kali)

Jim Hill's tumblemustard (Sisymbrium altissimum)

Grasses cheatgrass (Bromus tectorum)

Sandberg's bluegrass (Poa sandbergii)

Plant Cover Between Shrubs (0.5 $\mathrm{m}^{2}$ Plot)

Greatest plant cover: $\quad 100 \%$-- cheatgrass

trace of Jim Hill's tumblemustard

Least plant cover: $\quad 40 \%$-- cheatgrass

$5 \%$-- Sandberg's bluegrass 
$10 \%$-- exposed ground with moss and lichen crust

$45 \%$-- bare ground.

\section{200 ENC (200 East, North Central)}

Benton County, EMA Location No. 6362

GPS: $X$ Position $=573714 ; \mathrm{Y}$ Position $=137817$

The 200 ENC site is located about 200 feet north of the 200-East Area perimeter fence across from the intersection of 12 th St. and Baltimore. Ave. The $200 \mathrm{ENC}$ air sampling station is located on the inside of the perimeter fence at the same intersection. The soil sampling site is marked with an "Environmental Sampling Location" sign. The specific sampling site is a few feet north of the sign.

General Site Description The sampling site is located within a sagebrush/Sandberg bluegrasscheatgrass habitat. The general topography is flat. Widely spaced sagebrush plants are present with no evidence of recent wildfire. The soil is probably loamy sand. Some of the soil surface in open areas is crusted with mosses and lichens.

Current Land Use The site is idle and has not been used for agricultural production since the Hanford Site was established. The land probably has never been plowed because it is only marginally suitable for dryland farming, and irrigation water was not available. The area may have been disturbed during construction activities at the 200 East Area. The present condition of the site is probably similar to that in 1977 when the site was established.

Sampling History Samples were collected from the 0-1 inch layer of surface soil at this site each year from 1977 through 1994, except 1990 and 1992.

\section{Predominant Plant Species Present}

Shrubs: $\quad$ big sagebrush (Artemisia tridentata)

Forbs: $\quad$ Russian thistle (Salsola kali)

Carey's balsamroot (Balsamorhiza careyana)

yellow salsify (Tragopogon dubius)

Grasses: $\quad$ cheatgrass (Bromus tectorum)

Sandberg's bluegrass (Poa sandbergii)

Plant Cover Between Shrubs (0.5 $\mathrm{m}^{2}$ Plot)

Greatest plant cover: $\quad 80 \%$-- cheatgrass

$20 \%$-- Sandberg's bluegrass 
Least plant cover:

$80 \%$-- Sandberg's bluegrass

$20 \%$-- exposed ground with moss and lichen crust

\section{200 ESE (200 East, Southeast; a.k.a. 200 East Hill, Control Plot \#61, and 200 East Air Sampling Station)}

Benton County, EMA Location No. 6022

GPS: $X$ Position $=576315 ;$ Y Position $=134592$

The soil sampling site is located near the 200 ESE air sampling station at the top of the 200 East hill on Hanford Highway Route 4 South and about 0.5 mile east of the southeast corner of the 200-East Area. The soil collection site is marked with an "Environmental Sampling Location" sign. The specific soil sampling site is about 50 feet west of the sign and some 200 feet west of a cement block building near the current 200 ESE air sampling station.

General Site Description The sampling site is located within a sagebrush/needle-and-thread grasscheatgrass habitat. The general topography is rolling, consisting of stabilized sand dunes. Some sagebrush plants show scaring by recent wildfire. The soil is probably sand. Some of the soil surface is crusted with mosses and lichens in well vegetated areas, but most of the surface is bare soil in open areas.

Current Land Use The site is currently idle but is near an abandoned army antiaircraft gun emplacement. The area may have been disturbed during construction and operation of the army encampment in the 1940s and 1950s. The site has not been used for agricultural production since the Hanford Site was established and probably has never been plowed because of the sandy nature of the soil and the lack of irrigation water. The present condition of the site is probably similar to that in the mid-1970s when routine soil sampling began.

Sampling History The EMA number for this site was used to identify samples collected from the 0-1 inch layer of surface soil each year from 1971 through 1994, except 1990 and 1992. In 1971 and 1972 , samples were also collected from the 1-2 inch layer of soil. In 1973, additional samples were collected from the 1-2 inch, 2-4 inch, 4-8 inch, and 8-12 inch layers of soil. However, as noted in Section 2.2.3 of this report, the original sampling site for this EMA number was located at the bottom of the 200 East hill, near a telephone line crossing over Highway 4 South, about 2.25 miles east of the PUREX plant stack. The sampling site apparently was moved to the present location in the mid1970 s.

\section{Predominant Plant Species Present}

Shrubs: $\quad$ big sagebrush (Artemisia tridentata) green rabbitbrush (Chrysothamnus viscidiflorus) 
Forbs: $\quad$ yarrow (Achillea millefolium)

turpentine springparsley (Cymopteris terebinthinus)

Grasses: $\quad$ needlè-and-thread grass (Stipa comata)

indian ricegrass (Oryzopsis hymenoides)

cheatgrass (Bromus tectorum)

Sandberg's bluegrass (Poa sandbergii)

\section{Plant Cover Between Shrubs (0.5 $\mathrm{m}^{2}$ Plot)}

Greatest plant cover:

Least plant cover:

\section{Hanford Townsite}

Benton County, EMA Location No. 6017

GPS: $\mathrm{X}$ Position $=584226 ; \mathrm{Y}$ Position $=139807$

The Hanford Townsite soil sampling site is located on the west side of Hanford Highway Route 2 North about 0.7 mile north of the intersection with Hanford Highway Route 11A. The soil collection site is marked with an "Environmental Sampling Location" sign about 80 yards west of Hanford Highway Route 2 North. The specific soil sampling site is within the general vicinity of the sign.

General Site Description The sampling site is located within a sagebrush/cheatgrass habitat. The general topography is gently undulating, but shows signs of being highly disturbed, probably during the time of major construction at Hanford and of housing for workers at Camp Hanford located just east of Hanford Highway Route 2 North. Before the Hanford Project, the general area was the site of the old town of Hanford and agricultural production. Mature sagebrush plants are present and do not show scaring by wildfire. The soil is probably loamy sand, but areas with surface gravel are present, probably spread from various kinds of historical construction activities. The development of a soil surface crust of mosses and lichens is mostly absent.

Current Land Use The site is currently idle but obviously associated with historical activities at Camp Hanford. The area may have been used for farmland before 1942 because of the nearby location of abandoned irrigated fields. However, the present condition of the site is probably similar to that in 1971 when routine soil sampling began. 
Sampling History Samples were collected from the 0-1 inch layer of surface soil at this site each year from 1971 through 1993, except 1974, 1986, 1990, and 1992. In 1971 and 1972, samples were also collected from the 1-2 inch layer of soil.

\section{Predominant Plant Species Present}

Shrubs: $\quad$ big sagebrush (Artemisia tridentata)

Forbs: $\quad$ yellow starthistle (Centaurea solstitialis)

Jim Hill's tumblemustard (Sisymbrium altissimum)

yellow salsify (Tragopogon dubius)

Grasses: $\quad$ sand dropseed (Sporobolus cryptondrus)

cheatgrass (Bromus tectorum)

Sandberg's bluegrass (Poa scondbergii)

Plant Cover Between Shrubs (0.5 $\mathrm{m}^{2}$ Plot)

Greatest plant cover:

$$
\begin{aligned}
& 80 \% \text { - cheatgrass } \\
& 10 \% \text {-- Sandberg's bluegrass } \\
& 10 \% \text {-- sand dropseed }
\end{aligned}
$$

Least plant cover: $\quad 100 \%$-- cheatgrass (short stems)

7. SE FFTF (Southeast of the Fast Flux Test Facility; a.k.a. Southeast Side of FFTF, SE Side of FFTF, and 400-S)

Benton County, EMA Location No. 6277

GPS: $\mathrm{X}$ Position $=587939 ; \mathrm{Y}$ Position $=122656$

The soil sampling site southeast of FFTF is located near the southeast corner of the 400 Area and east of the 400 Area 30-meter-high meteorology tower. The site is marked with an "Environmental Sampling Location" sign about 100 feet south of the 400 Area perimeter road. The specific soil sampling site is within the general vicinity of the sign.

General Site Description The general area of the sampling site is within a sagebrush/bitterbrushcheatgrass habitat. The topography is rolling with stabilized sand dunes. The tops of the stabilized dunes tend to have blow-out areas with little or no vegetation. There are no large shrubs within the sampling site due to a wildfire that burned the area in the mid-1980s. The soil is probably sand. Some soil surface in vegetated areas is crusted with mosses and lichens.

Current Land Use The site is currently idle and has not been used for agricultural production since the Hanford Site was established. The site has never been plowed because of the sandy nature of the 
soil, the presence of sand dunes, and the absence of irrigation water. The present condition of the site is probably similar to that in 1975 except for fire damage to the vegetation and perhaps drifting sand near wind blow-out areas.

Sampling History Samples were collected from the 0-1 inch layer of surface soil at SE FFTF site each year from 1975 through 1994, except 1976, 1987, 1990, and 1992. FFTF Control Plot 62 (a.k.a. FFTF CP 62; EMA No. 6015) was established to collect soil samples during the construction phase at the FFTF. Samples were collected from the 0-1 inch layer of surface soil from 1971 through 1974, and from the 1-2 inch layer in 1971 and 1972. FFTF Control Plot 62 was located between the current SE FFTF and NE FFTF sampling locations. Because of their proximity, results from samples collected at the three FFTF locations are considered equivalent. Results for FFTF Control Plot 62 are included in Appendix B.

\section{Predominant Plant Species Present}

Shrubs: none present

Forbs: $\quad$ hoary aster (Machaeranthera canescens)

bur ragweed (Ambrosia acanthicarpa) jagged chickweed (Holosteum umbellatum) turpentine springparsley (Cymopteris terebinthinus) pale evening primrose (Oenothera pallida)

Grasses: $\quad$ cheatgrass (Bromus tectorum) Sandberg's bluegrass (Poa sandbergii)

Plant Cover Between Shrubs (0.5 $\mathrm{m}^{2}$ Plot)

Greatest plant cover:

$85 \%$-- cheatgrass

$5 \%$-- Sandberg's bluegrass

$10 \%$-- exposed ground with moss and lichen crust

Least plant cover: $\quad 5 \%$-- pale evening primrose

$95 \%$-- bare ground

8. NE FFTF (Northeast of the Fast Flux Test Facility; a.k.a. Northeast Side of FFTF, 0.5 mi NE FFTF, and 400-E)

Benton County, EMA Location No. 6282

GPS: $\mathrm{X}$ Position $=587936 ; \mathrm{Y}$ Position $=123337$

The soil sampling site is located northeast of FFTF opposite the east fence of the 400 Area and several hundred yards northeast of the old visitors center building. The site is marked with an 
"Environmental Sampling Location" sign and is near a 10-meter-high meteorology tower. The specific soil sampling site is the general area east of the sign.

General Site Description The site is very similar to the SE FFTF site. The general area is a sagebrush/bitterbrush-cheatgrass habitat with rolling topography associated with stabilized sand dunes. The tops of the stabilized dunes tend to have blow-out areas with little or no vegetation. There are no living shrubs within the sampling area due to a wildfire that burned the area in the mid$1980 \mathrm{~s}$. Burned stumps of sagebrush, bitterbrush, and rabbitbrush are present. The soil is probably sand. Some of the soil surface in vegetated areas is crusted with mosses and lichens.

Current Land Use The site is currently idle and has not been used for agricultural production since the Hanford Site was established. The site has never been plowed because of the sandy nature of the soil, the presence of sand dunes, and the absence of irrigation water. The present condition of the site is probably similar to that in 1975 when the site was established except for fire damage to the vegetation and perhaps wind-blown sand. The site is physically closer to the FFTF facility than the SE FFTF sampling location, but probably was not disturbed extensively by construction activities.

Sampling History Samples were collected from the 0-1 inch layer of surface soil at this site each year from 1975 through 1994, except 1986, 1990, and 1992. (See comments under Sampling History for SE FFTF regarding soil sampling at FFTF Control Plot 62, EMA No 6015.)

\section{Predominant Plant Species Present}

Shrubs: $\quad$ none present

Forbs: $\quad$ hoary aster (Machaeranthera canescens)

bur ragweed (Ambrosia acanthicarpa)

Russian thistle (Salsola kali)

Grasses: cheatgrass (Bromus tectorum)

Sandberg's bluegrass (Poa sandbergii)

Plant Cover Between Shrubs $\left(0.5 \mathrm{~m}^{2}\right.$ Plot)

Greatest plant cover:

$70 \%$-- Sandberg's bluegrass

$5 \%$-- cheatgrass

$20 \%$-- exposed ground with moss and lichen crust

$5 \%$-- bare ground

Least plant cover:

$20 \%$ - mixture of cheatgrass, Sandberg's bluegrass, hoary aster, bur ragweed

$80 \%$-- bare ground 


\section{Wye Barricade}

Benton County, EMA Location No. 6016

GPS: $\mathrm{X}$ Position $=585106 ; \mathrm{Y}$ Position $=128238$

The site is located east of the Wye Barricade at the junction of Hanford Highway Route 4 South, Hanford Highway Route 2 South, and Hanford Highway Route 10. The soil sampling site, air sampling station, and 10-meter-high meteorology tower were moved to the present location from the west side of the highway in the late 1980 s when the roads were relocated and the guard house replaced. The old and current sites are very similar in vegetation, topography, and historical use. The current soil sampling site is near a 10-meter-high meteorology tower and marked with an "Environmental Sampling Location" sign. The specific sampling site is within the general vicinity (south and east) of the sign.

General Site Description The site is located in a bitterbrush-sagebrush/cheatgrass habitat. The general topography of the site is undulating with stabilized sand dunes. The soil at the sampling site is sand or loamy sand. No living shrubs are present, but there are charred remains from a wildfire that burned through the area in the mid-1980s. Ant hills are prominent. The soil surface is not crusted with mosses and lichens.

Current Land Use The site is idle and has not been used for agricultural production since the Hanford Site was established. The land probably has never been plowed because of the sandy nature of the soil and the lack of irrigation water. The present condition of the site is probably similar to the original site established across the highway in 1971 except for the absence of shrubs due to wildfire.

Sampling History Samples were collected from the 0-1 inch layer of surface soil at this site (i.e., EMA number) each year from 1971 through 1993, except 1974, 1975, 1976, 1986, 1990, and 1992. In 1971 and 1972 samples were also collected from the 1-2 inch layer of soil. As noted earlier, the sampling site was relocated from across the highway in the late 1980s, but the EMA number was retained.

\section{Predominant Plant Species Present}

Shrubs: none present (charred stems of big sagebrush)

Forbs: $\quad$ dune scurfpea (Psoralea lancelolata) jagged chickweed (Holosteum umbellatum) pale evening primrose (Oenothera pallida) bur ragweed (Ambrosia acanthicarpa) matted cryptantha (Cryptantha circumscissa) Russian thistle (Salsola kali) 
Grasses: $\quad$ cheatgrass (Bromus tectorum)

Sandberg's bluegrass (Poa sandbergii)

Plant Cover Between Shrubs (0.5 $\mathrm{m}^{2}$ Plot)

Greatest plant cover: $\quad 95 \%$-- cheatgrass

$5 \%$-- Sandberg's bluegrass

Least plant cover: $\quad 5 \%$-- cheatgrass and jagged chickweed

$95 \%$-- bare ground

\section{Prosser Barricade}

Benton County, EMA Location No. 6225

GPS: $\mathrm{X}$ Position $=583681 ; \mathrm{Y}$ Position $=118275$

The sampling site is located on the west side of Hanford Highway Route 10 across from the "Restricted Government Area" signboard and the air sampling station at the old Prosser Barricade where Route 10 exits the southern boundary of the Hanford Site to State Highway 240. The soil sampling site is located about 100 yards west of the highway and is marked with an "Environmental Sampling Location" sign. The specific sampling site is within the general vicinity (west) of the sign on a gentle east-facing slope.

General Site Description The site is located in a bitterbrush-sagebrush/cheatgrass habitat. The general topography of the site is undulating with stabilized sand dunes. The soil at the sampling site is probably sand. No living shrubs are present, but charred remains of antelope bitterbrush indicate the general area was recently burned. Living gray rabbitbrush and young antelope bitterbrush shrubs are present in the vicinity. The exposed soil surface is crusted with mosses and lichens.

Current Land Use The site is idle and has not been used for agricultural production since the Hanford Site was established. The land probably has never been plowed because of the sandy soil and the lack of irrigation water. The present condition of the site is probably similar to the original site established in 1974 except for the absence of shrubs due to a wildfire that occurred in the mid-1980s.

Sampling History Samples were collected from the 0-1 inch layer of surface soil at this site each year from 1974 through 1993, except 1976, 1987, 1990, 1991, and 1992.

\section{Predominant Plant Species Present}

Shrubs: $\quad$ snow buckwheat (Eriogonum niveum) (charred stems of antelope bitterbrush)

Forbs: $\quad$ Russian thistle (Salsola kali) 
$\begin{array}{ll}\text { Grasses: } & \text { cheatgrass (Bromus tectorum) } \\ & \text { Sandberg's bluegrass (Poa sandbergii) }\end{array}$

Plant Cover Between Shrubs (0.5 $\mathrm{m}^{2}$ Plot)

Greatest plant cover: $\quad 50 \%$-- cheatgrass

$50 \%$-- Sandberg's bluegrass

Least plant cover: $\quad 50 \%$-- Sandberg's bluegrass

$5 \%$-- Russian thistle (seedlings)

$45 \%$-- exposed ground with moss and lichen crust

11. ALE (Arid Land Ecology Reserve; a.k.a ALE Field Lab and East of Arid Land Ecology Lab)

Benton County, EMA Location No. 6278

GPS: $\mathrm{X}$ Position $=574657 ; \mathrm{Y}$ Position $=118316$

The sampling site is located on the Fitzner/Eberhardt Arid Land Ecology Reserve near the intersection of the paved road, leading to the Emergency Relocation Center (ERC), and the ALE field laboratory buildings with the dirt 1200 -foot road. The soil sampling site is located about 50 yards west of the intersection, and is marked with an "Environmental Sampling Location" sign. The specific sampling site is within the general vicinity south (slightly upslope) of the sign.

General Site Description The site is located in a sagebrush/bluebunch wheatgrass habitat. The general topography of the site is flat with a slight north-facing aspect. The soil-at the sampling site is probably silt loam. No living shrubs are present on the sampling site because the area was recently burned, but a few young sagebrush plants are present nearby. The exposed soil surface is well crusted with mosses and lichens.

Current Land Use The site is idle and has not been used for agricultural production since the Hanford Site was established except for stray cattle and possibly some sheep grazing. The ALE Reserve was established in the mid-1960s when sheep grazing was discontinued, and the entire ALE Reserve was fenced to exclude stray livestock. No livestock grazing has occurred since the soil sampling site was established in 1975 . The land has never been plowed. The present condition of the site is probably similar to that in 1975 except for damage by wildfire in the mid-1980s.

Sampling History Samples were collected from the 0-1 inch layer each year from 1975 through 1993, except 1986, 1990, 1991, and 1992. This general location was originally sampled from 1971 through 1974 at the ERC (EMA No. 6001) about 0.25 mile south of the current ALE sampling site. Samples were collected from the 0-1 inch layer of surface soil and also from the 1-2 inch layer in 1971 and 1972. Because of their proximity, results from samples collected at both locations are considered equivalent. Results for the ERC location are included in Appendix B. 


\section{Predominant Plant Species Present}

Shrubs: none present (except for charred stems of sagebrush)

Forbs: $\quad$ velvet lupine (Lupinus leucophyllus)

Carey's balsamroot (Balsamorhiza careyana)

hoary aster (Machaeranthera canescens)

Cusick's sunflower (Helianthus cusickii)

yellow salsify (Tragopogon dubius)

slender hawksbeard (Crepis atrabarba)

Jim Hill's tumblemustard (Sisymbrium altissimum)

threadleaf fleabane (Erigeron filifolius)

Grasses: $\quad$ bluebunch wheatgrass (Agropyron spicatum a.k.a. Pseudoroegneria spicata)

needle-and-thread grass (Stipa comata)

bottlebrush squirreltail (Sitanion hystrix)

cheatgrass (Bromus tectorum)

Sandberg's bluegrass (Poa sandbergii)

Plant Cover Between Shrubs (0.5 $\mathrm{m}^{2}$ Plot)

Greatest plant cover:

$75 \%$-- cheatgrass

$25 \%$-- lupine

Least plant cover:

$$
\begin{aligned}
& 30 \% \text { - needle-and-thread grass } \\
& 25 \% \text {-- Sandberg's bluegrass } \\
& 15 \% \text {-- lupine } \\
& 15 \% \text {-- salsify } \\
& 5 \% \text {-- cheatgrass } \\
& 10 \% \text {-- exposed ground with moss and lichen crust }
\end{aligned}
$$

\subsubsection{Offsite Sampling Locations}

\section{Benton City}

Benton County, EMA Location No. 6000

GPS: $\mathrm{X}$ Position $=577989$; $\mathrm{Y}$ Position $=111904$

The site is located 4.8 miles southwest of State Highway 240 on Horn Road, State Highway 240. It is near the old southern boundary of the Hanford Site on the west side of Horn Road and north of Benton City. The soil sampling site is located on a ridge about 150 yards west of the highway and is marked with an "Environmental Sampling Location" sign. The specific sampling site is within the general vicinity of the sign. 
General Site Description The site is located in a sagebrush/bluegrass-cheatgrass habitat. The general topography of the site is an east-facing slope with knolls. The soil at the sampling site is probably silt loam. Some living sagebrush are present on the sampling site but the area shows signs of wildfire having occurred sometime in the past. Exposed soil surfaces are covered with a crust of mosses and lichens to the extent that soil erosion is not evident despite the rather steep topography.

Current Land Use The site probably was located near or within the original Hanford Site boundary, but the area has been managed by Washington State Department of Game as a public hunting area since the early 1970s when the southern boundary of the Hanford Site was relocated. The area has not been used for significant cattle or sheep grazing since the soil sampling site was established. The land has never been plowed because of the steep terrain. The present condition of the site is probably similar to that present when sampling began except for damage from wildfire that probably occurred in the mid-1980s.

Sampling History Samples identified with the EMA number for this location were collected from the 0-1 inch layer of surface soil each year from 1971 through 1993, except 1975, 1976, 1990, 1991, and 1992. In 1971 and 1972 samples were also collected from the 1-2 inch layer of soil. As noted in Section 2.2.3, the original sampling site for this location may have been at the PUD electrical distribution substation on the outskirts (north) of Benton City. It may have been relocated to the present site in the mid-1970s.

\section{Predominant Plant Species Present}

Shrubs: $\quad$ big sagebrush (Artemisia tridentata)

Forbs: $\quad$ hoary aster (Machaeranthera canescens)

Jim Hill's tumblemustard (Sisymbrium altissimum)

threadleaf fleabane (Erigeron filifolius)

Grasses: $\quad$ cheatgrass (Bromus tectorum)

Sandberg's bluegrass (Poa sandbergii)

indian ricegrass (Oryzopsis hymenoides)

slender sixweeks fescue (Festuca octoflora a.k.a. Vulpia octoflora)

Plant Cover Between Shrubs (0.5 $\mathrm{m}^{2}$ Plot)

Greatest plant cover: $\quad 100 \%$-- cheatgrass

Least plant cover: $\quad 50 \%$-- cheatgrass

$10 \%$-- slender sixweeks fescue

$40 \%$-- exposed ground with moss and lichen crust 


\section{Sunnyside}

Yakima County, EMA Location No. 6357

GPS: $\mathrm{X}$ Position $=542335 ; \mathrm{Y}$ Position $=118579$

The sampling site is located northeast of the town of Sunnyside on the east side of Hanford Road, Highway 241, two miles north of the intersection with Independence Road. The soil sampling site is located in an open field across the road (east) from the only farmhouse in the area. The site is on private property and not marked with an "Environmental Sampling Location" sign. The specific sampling site is several hundred feet east of the highway in an open field (across a fence) near an electric power pole.

General Site Description The site is located in a sagebrush/bluebunch wheatgrass-cheatgrass habitat. The general topography of the site is flat with a gentle south-facing slope. The soil at the sampling site is probably silt loam. No living sagebrush is present on the sampling site, but it does occur nearby. Exposed soil surface is crusted with mosses and lichens.

Current Land Use The area is lightly grazed as evidenced by a few weathered cow chips. However, the site is not overgrazed because of the presence of a soil crust on most exposed soil surfaces. The site probably has been used for livestock grazing since it was established in 1977 . The land probably has never been plowed because of the lack of irrigation water and a marginal climate for dryland grain production. The present condition of the site is probably similar to that in 1977 when the site was established.

Sampling History The Sunnyside sampling location was established in 1977 and has been sampled each year through 1993. Samples were collected from the 0-1 inch layer of surface soil. As part of a special study in 1988, samples were collected in 1-inch increments from the surface to a depth of 12 inches (Price 1991).

\section{Predominant Plant Species Present}

Shrubs: none present

Forbs: hoary aster (Machaeranthera canescens)

jagged chickweed (Holosteum umbellatum) longleaf phlox (Phiox longifolia)

Grasses: $\quad$ bluebunch wheatgrass (Agropyron spicatum a.k.a. Pseudoroegneria spicata) cheatgrass (Bromus tectorum) Sandberg's bluegrass (Poa sandbergii) 
Plant Cover Between Shrubs (0.5 $\mathrm{m}^{2}$ Plot)

$\begin{array}{ll}\text { Greatest plant cover: } & 90 \% \text {-- cheatgrass } \\ & 10 \% \text { - jagged chickweed } \\ \text { Least plant cover: } & 60 \% \text {-- bluebunch wheatgrass } \\ & 15 \% \text {-- Sandberg's bluegrass } \\ 5 \%-- \text { jagged chickweed } \\ 10 \% \text { - exposed ground with moss and lichen crust } \\ 10 \%-\text { - bare ground }\end{array}$

\section{Harris Farm (a.k.a. Riverview-Harris Farm)}

Franklin County, EMA Location No. 6361

GPS: $\mathrm{X}$ Position $=596658 ; \mathrm{Y}$ Position $=104928$

The location was established in 1977 a few hundred yards west of the out-buildings at the Harris Farm on the north side of Court Street near the intersection with Road 100 in the Riverview district of Pasco. The location was changed from Riverview - Control Plot 55 to coincide with samples of produce, meat, and milk obtained from the Harris Farm. The current soil sampling site is in an open field near the Columbia River and irrigated farming on private property. The site is not marked with an "Environmental Sampling Location" sign. The specific sampling site is within the general area west of a dirt road that runs along a row of trees that is part of the Harris Farm.

General Site Description The site is located in a bitterbrush-sagebrush/cheatgrass habitat although neither antelope bitterbrush nor big sagebrush are present at the specific sampling site; these shrubs do occur nearby. The general topography of the site is undulating with medium-sized, stabilized sand dunes present. The soil at the sampling site is probably sand. A small amount of the exposed soil surface is crusted with mosses and lichens.

Current Land Use This open field is currently idle but was grazed sometime in the past. The site has not been grazed extensively in recent time because of the slight development of a moss and lichen crust on the soil surface especially beneath the canopy of rabbitbrush shrubs. The land probably has never been plowed because the sand dunes would have been leveled. The present condition of the site is probably similar to that in 1977 when the site was established.

Sampling History Samples were collected from the 0-1 inch layer of surface soil at the Harris Farm site each year from 1977 through 1994, except 1990. A sampling site known as Riverview - Control Plot 55 was established in 1971 at the intersection of Taylor Flats Road and Road 68 in Pasco, Washington, several miles northeast of the Harris Farm. The Riverview - Control Plot 55 site was sampled from 1971 through 1974, but is not considered supplementary or equivalent to the Harris Farm site because of the distance separating the two sites. 


\section{Predominant Plant Species Present}

Shrubs: $\quad$ gray rabbitbrush (Chrysothamnus nauseosus)

green rabbitbrush (Chrysothamnus viscidiflorus)

Forbs: dune scurfpea (Psoralea lanceolata)

jagged chickweed (Holosteum umbellatum)

pale eveningprimrose (Oenothera pallida)

Winged dock (Rumex venosus)

Grasses: $\quad$ cheatgrass (Bromus tectorum)

Sandberg's bluegrass (Poa sandbergii)

Plant Cover Between Shrubs (0.5 $\mathrm{m}^{2}$ Plot)

Greatest plant cover:

$90 \%$-- cheatgrass

$5 \%$ - jagged chickweed

$5 \%$-- exposed bare ground

Least plant cover:

$10 \%$-- green rabbitbrush

$5 \%$-- cheatgrass

$5 \%$-- pale eveningprimrose

$75 \%$ - bare ground

$5 \%$-- exposed ground with moss and lichen crust

\section{Byers Landing}

Franklin County, EMA Location No. 6011

GPS: $X$ Position $=596616$; Y Position $=114789$

The sampling site is located adjacent to an irrigated field about 0.6 mile east of County Road 68 near the Byers Landing air sampling station. The soil sampling site is located on private property in an open field about 0.1 mile beyond (east) of the Byers Landing air sampling station. The site is on the east side of the second dirt road that makes a sharp left turn (north) away from the Esquatzel Waste Way (irrigation water return canal). The site is not marked with an "Environmental Sampling Location" sign. The specific sampling site is near an electric power pole about 100 feet north of the sharp left turn and about 100 feet east of the dirt road. The site was moved about 0.1 mile east of the original sampling location in 1992, which is now under cultivation.

General Site Description The site is located in a sagebrush/cheatgrass habitat. The general topography of the site is undulating, and the soil is probably sand or loamy sand. Some exposed soil surface is crusted with mosses and lichens. Irrigated fields and canals are nearby. 
Current Land Use This field is currently idle but undoubtedly has been used for limited grazing. However, the site has not been grazed extensively in recent times because of the absence of manure and the presence of a moss and lichen crust on some of the soil surface. The land has not been plowed since the site was established because of the presence of large sagebrush plants. The present condition of the site is probably similar to that in 1971 at the original sampling site.

Sampling History Samples were collected from the 0-1 inch layer of surface soil at the Byers Landing location each year from 1971 through 1994, except 1975. In 1971 and 1972 samples were also collected from the 1-2 inch layer of soil. As noted above, the original sampling site for this location was across the road from the Byers Landing air sampling station about 0.1 mile west of the current site. Samples collected from either site are considered equivalent.

\section{Predominant Plant Species Present}

Shrubs: $\quad$ big sagebrush (Artemisia tridentata) green rabbitbrush (Chrysothamnus viscidiflorus)

Forbs: 'Jim Hill's tumblemustard (Sisymbrium altissimum) tarweed fiddleneck (Amsinckia lycopsoides) indian wheat (Plantago patagonica) Carey's balsamroot (Balsamorhiza careyana) prickley pear cactus (Opuntia spp.)

Grasses: $\quad$ cheatgrass (Bromus tectorum) indian ricegrass (Oryzopsis hymenoides)

Sandberg's bluegrass (Poa sandbergii)

Plant Cover Between Shrubs (0.5 $\mathrm{m}^{2}$ Plot)

Greatest plant cover: $\quad 100 \%$ - cheatgrass

Least plant cover: $\quad \cdot 20 \%--$ cheatgrass

$75 \%$-- bare ground

$5 \%$-- exposed ground with moss and lichen crust

5. Sagemoor (a.k.a. Sagemore Farm)

Franklin County, EMA Location No. 6358

GPS: $\mathrm{X}$ Position $=596524$; Y Position $=116256$

The sampling site is located in a small field among irrigated orchards and vineyards just off of County Road 68 across from the main entrance to Sagemoor Farms. The soil sampling site is located on private property in a fenced field several hundred feet south of County Road 68. The site is not 
marked with an "Environmental Sampling Location" sign. The specific sampling site is about 100 feet past a wire gate across a dirt road that follows a row of Lombardy poplar trees forming a windbreak adjacent to an apple orchard.

General Site Description The site is located in a sagebrush/cheatgrass habitat. The general topography of the site is west sloping, and the soil is probably sand. The field is highly disturbed from recent livestock grazing. The exposed soil surface is not crusted with mosses and lichens.

Current Land Use This field is currently in an over-grazed condition from use by cattle and horses. The soil surface is trampled, and much fresh manure is present. The land has not been plowed since 1977 as evidenced by the presence of large sagebrush shrubs. The present condition of the site compared to 1977 is unknown. The field probably has always been used for livestock grazing, but may be used more intensively now than in the past.

Sampling History Samples were collected from the 0-1 inch layer of surface soil at this site each year from 1977 through 1994.

\section{Predominant Plant Species Present}

Shrubs: $\quad$ big sagebrush (Artemisia tridentata) gray rabbitbrush (Chrysothamnus nauseosus)

Forbs: $\quad$ Russian thistle (Salsola kali) yarrow (Achillea millefolium) puncture vine (Tribulus terrestris)

Grasses: cheatgrass (Bromus tectorum)

Plant Cover Between Shrubs (0.5 $m^{2}$ Plot)

$\begin{array}{ll}\text { Greatest plant cover: } & 90 \% \text {-- cheatgrass } \\ & 10 \% \text {-- bare ground } \\ \text { Least plant cover: } & 95 \% \text {-- trampled bare ground } \\ & 3 \% \text { - Russian thistle (immature plants) } \\ 2 \%-\text { - puncture vine }\end{array}$




\section{Fir Road (a.k.a. W end of Fir Road)}

Franklin County, EMA Location No. 6360

GPS: $X$ Position $=595986 ; \mathrm{Y}$ Position $=124268$

The sampling site is located in an open field among irrigated vineyards near the west end of Fir Road. The soil sampling site is located on private property on the south side of the road in the vicinity of the Fir Road air sampling station. The site is not marked with an "Environmental Sampling Location" sign. The specific sampling site is about 100 feet south of the air sampling station.

General Site Description The site is located in a sagebrush/cheatgrass habitat on a west-facing slope overlooking the Columbia River. The soil is probably loamy sand. The field has not been used for grazing for many years because of the presence of a well-developed crust of mosses and lichens on a stable soil surface. However, cheatgrass is prevalent indicating severe disturbance at some time in the past.

Current Land Use This field is currently idle. The land probably has never been plowed because of the presence of large sagebrush plants. The land is suitable for a vineyard or orchard. The present condition of the site is probably similar to that in 1977 when the site was established for soil sampling.

Sampling History Samples were collected from the 0-1 inch layer of surface soil at this site each year from 1977 through 1993, except 1990, 1991, and 1992.

\section{Predominant Plant Species Present}

Shrubs: $\quad$ big sagebrush (Artemisia tridentata) green rabbitbrush (Chrysothamnus viscidiflorus)

Forbs: $\quad$ slender hawksbeard (Crepis atrabarba) yarrow (Achillea millefolium) snow buckwheat (Eriogonum niveum)

Grasses: $\quad$ cheatgrass (Bromus tectorum) Sandberg's bluegrass (Poa sandbergii) needle-and-thread grass (Stipa comata)

Plant Cover Between Shrubs (0.5 $\mathrm{m}^{2}$ Plot)

Greatest plant cover: $\quad 100 \%$-- cheatgrass 
Least plant cover

$80 \%$-- Sandberg's bluegrass

$20 \%$-- exposed ground with moss and lichen crust

\section{Taylor Flats No. 2}

Franklin County, EMA Location No. 6421

GPS: $\mathrm{X}$ Position $=595595 ; \mathrm{Y}$ Position $=120949$

This soil sampling site is now part of a private residence. The dirt entrance road, as shown in the locations manuals, was recently developed into a driveway leading to a house. The original soil sampling site was located at the base of the hillside about 0.2 mile east of the river road extension of Fir Road, but the location is uncertain because the general area is currently well used. The site was not marked with an "Environmental Sampling Location" sign. The entrance road is about $2.1 \mathrm{miles}$ south of the end of Fir Road, but was originally described as 2.6 miles north of the end of the pavement on the river road extension of County Road 68 (at Sagemoor Farms). Landslides blocked the river road extension of Road 68 in 1983.

If sampling is resumed at this location, the specific sampling site should be moved to a similar field about 0.1 mile north. This site is located on private property east and upslope from the river road extension of Fir Road. The sampling site is near the top of a steep driveway, which is about 2 miles south of the end of Fir Road (hence, 0.1 mile north of the dirt road to the original site). The specific sampling site should be located about 200 yards south and upslope of the house at the top of a driveway. The GPS data given above are for this proposed sampling site.

General Description of the Proposed Site The proposed site is located in an abandoned field within a sagebrush/cheatgrass habitat on a west facing slope overlooking the Columbia River. The soil is probably loamy sand. The field has been used for livestock grazing in the past and probably was plowed sometime before 1978. There is only a slight development of a crust of mosses and lichens on the soil surface. Sagebrush bushes are present in the general area but not on the sampling site. A few wild alfalfa plants are growing nearby.

Current Land Use at the Proposed Site This field is currently idle, but the area is suitable for irrigated agriculture and may be developed before long. Land nearby (north and east) currently is being prepared for either a vineyard or an orchard. The present condition of this site is probably similar to that present at the original site when it was established for soil sampling in 1978.

Sampling History at the Original Site Samples were collected from the 0-1 inch layer of surface soil at the original site each year from 1978 through 1993, except 1991 and 1992. 
Predominant Plant Species Present at the Propose Site

Shrubs: none present

Forbs: $\quad$ yellow salsify (Tragopogon dubius)

prickly lettuce (Lactuca serriola)

alfalfa (Medicago sativa)

Grasses: cheatgrass (Bromus tectorum)

Sandberg's bluegrass (Poa sandbergii)

Plant Cover Between Shrubs (0.5 $\mathrm{m}^{2}$ Plot)

Greatest plant cover: $\quad 100 \%$-- cheatgrass

Least plant cover $\quad 90 \%$-- cheatgrass

$8 \%$-- Sandberg's bluegrass

$2 \%$-- exposed ground with moss and lichen crust

\section{Ringold (Ringold Area)}

Franklin County, EMA Location No. 6009

GPS: $X$ Position $=595847 ;$ Y Position $=129571$

The site is located south of the Ringold fish hatchery in a field on the east side of the river road near the gateway sign to Ringold Ranch. The soil sampling site is located on private property and is not marked with an "Environmental Sampling Location" sign. The specific sampling site is located about 50 feet east of the unpaved river road.

General Site Description The site is located on idle benchland at the base of a steep bluff across the road from an orchard. Groundwater seepage from irrigation at the top of the bluff is collected in a ditch at the base of the bluff and along the east edge of the sampling area. The ditch is vegetated with peachleaf willow, Russian olive, cattail, and Canadian thistle. The site has been used for stump and brush disposal but is mostly a sagebrush/cheatgrass habitat. The soil is probably loamy sand. The general area probably has been grazed sometime in the past before the orchard was developed, but currently it is too small to be used for grazing. Alfalfa plants are present, but the seeds could have been spread by birds from an adjacent field or the entire area could have been an alfalfa field before the dirt road was established. It is doubtful that the field has been plowed recently because of the presence of large sagebrush bushes. There is a slight crust of mosses and lichens on the soil surface. 
Current Land Use This field is currently idle and not suitable (too small) for agricultural development. The present condition of the site is probably similar to that in 1971 when the site was established for soil sampling except perhaps for the presence of groundwater seepage from on top of the bluff.

Sampling History Samples were collected from the 0-1 inch layer of surface soil at this site each year from 1971 through 1994, except 1974. Samples were also collected from the 1-2 inch layer of soil in 1971 and 1972.

\section{Predominant Plant Species Present}

Shrubs: $\quad$ big sagebrush (Artemisia tridentata)

gray rabbitbrush (Chrysothamnus nauseosus)

Forbs: $\quad$ alfalfa (Medicago sativa)

yellow salsify (Tragopogon dubius)

snow buckwheat (Eriogonum niveum)

Cusick's sunflower (Helianthus cusickii)

Carey's balsamroot (Balsamorhiza careyana)

Grasses: $\quad$ cheatgrass (Bromus tectorum)

Sandberg's bluegrass (Poa sandbergii)

wheatgrass (Agropyron spp.)

Plant Cover Between Shrubs (0.5 $\mathrm{m}^{2}$ Plot)

Greatest plant cover: $\quad 95 \%$-- cheatgrass

$5 \%$-- Sandberg's bluegrass

Least plant cover: $\quad 85 \%$-- cheatgrass

$5 \%$-- Sandberg's bluegrass

$10 \%$-- exposed ground with some moss and lichen crust

\section{Berg Ranch}

Franklin County, EMA Location No. 6421

GPS: $\mathrm{X}$ Position $=588293 ; \mathrm{Y}$ Position $=156850$

The sampling site is located in a field north of State Highway 24 and off the Hanford Site (near the eastern boundary). The soil sampling site is located on private property outside of a fenced exclusion area where the Berg Ranch air sampling station was located. The site is marked with an "Environmental Sampling Location" sign, and the specific sampling site is located about 50 yards west of the sign. 
General Site Description The site is located on grazing land within a sagebrush/cheatgrass habitat and on a gentle south-facing slope. The soil is probably loamy sand. The field has been used extensively for grazing. The land apparently has never been plowed. Any developing crust of mosses and lichens on the soil surface is mostly destroyed by grazing animals. Large and brokendown sagebrush bushes are present and the soil surface is trampled.

Current Land Use This field is currently in use for cattle grazing, as noted by the presence of fresh manure, and is in an overgrazed condition. Because of extensive animal disturbance, the present condition of the soil surface may not be the same as it was in 1971 when the sampling site was established.

Sampling History Samples were collected from the 0-1 inch layer of surface soil at this site each year from 1971 through 1993, except 1991 and 1992. In 1971 and 1972 samples were also collected from the 1-2 inch layer of soil.

\section{Predominant Plant Species Present}

Shrubs: $\quad$ big sagebrush (Artemisia tridentata)

Forbs: none present

Grasses: $\quad$ cheatgrass (Bromus tectorum)

Sandberg's bluegrass (Poa sandbergii)

Plant Cover Between Shrubs $\left(0.5 \mathrm{~m}^{2}\right.$ Plot)

Greatest plant cover: $\quad 50 \%$-- Sandberg's bluegrass

$50 \%$-- bare ground

Least plant cover: $\quad 99 \%$-- exposed ground with manure piles

$1 \%$-- Sandberg's bluegrass 


\subsection{References}

Blummer, P. J. 1979. Environmental Sampling Locations Manual. PNL-MA-514, Pacific Northwest Laboratory, Richland, Washington.

Blummer, P. J. 1981. Environmental Monitoring Procedures. PNL-MA-580, Pacific Northwest Laboratory, Richland, Washington.

Blummer, P. J., and J. P. Corley. 1971. EMA Program - User's Manual. BNWL-C-76, Pacific Northwest Laboratory, Richland, Washington.

Blummer, P. J., and J. J. Fix. 1977. EMA Program - User's Manual. BNWL-C-76, Rev. 1, Pacific Northwest Laboratory, Richland, Washington.

Bramson, P. E., and J. P. Corley. 1972. Environmental Surveillance at Hanford for CY-1971. BNWL-1683, Pacific Northwest Laboratory, Richland, Washington.

Bramson, P. E., and J. P. Corley. 1973. Environmental Surveillance at Hanford for CY-1972. BNWL-1727, Pacific Northwest Laboratory, Richland, Washington.

Corley, J. P., D. M. Robertson, and F. P. Brauer. 1971. Plutonium in Surface Soil in the Hanford Plant Environs. BNWL-SA-3967, Pacific Northwest Laboratory, Richland, Washington. Presented at the Environmental Plutonium Symposium, Los Alamos Scientific Laboratory, Los Alamos, New Mexico, August 5, 1971.

Fix, J. J. 1975. Environmental Surveillance at Hanford for CY-1974. BNWL-1910, Pacific Northwest Laboratory, Richland, Washington.

Hanf, R. W. 1995. Surface Environmental Surveillance Procedures Manual, Geosciences Department. PNL-MA-580, Pacific Northwest Laboratory, Richland, Washington.

Miller, M. L., J. J. Fix, and P. E. Bramson. 1977. Radiochemical Analyses of Soil and Vegetation Samples Taken from the Hanford Environs, 1971-1976. BNWL-224, Pacific Northwest Laboratory, Richland, Washington.

Nees, W. L., and J. P. Corley. 1975. Environmental Status of the Hanford Reservation for CY-1973. BNWL-B-336, Pacific Northwest Laboratory, Richland, Washington.

Poston, T. M., E. J. Antonio, and A. T. Cooper. 1995. Radionuclide Concentrations in Terrestrial Vegetation and Soil on and Around the Hanford Site, 1983 through 1993. PNL-10728, Pacific Northwest Laboratory, Richland, Washington. 
PNL. 1977. Hanford Environmental Surveillance Program: Technical Procedures Document. [no number], Pacific Northwest Laboratory, Richland, Washington.

PNL. 1983. Environmental Sampling Locations Manual. PNL-MA-514, Pacific Northwest Laboratory, Richland, Washington.

PNL. 1991. Environmental Sampling Locations Manual. SESP-SLM-01, Pacific Northwest Laboratory, Richland, Washington.

Price, K. R. 1988. A Review of Historical Data on the Radionuclide Content of Soil Samples Collected from the Hanford Site and Vicinity. PNL-6734, Pacific Northwest Laboratory, Richland, Washington.

Price, K. R. 1991. "The Depth Distribution of Sr-90, Cs-137, and Pu-239,240 in Soil Profile Samples." Radiochim. Acta 54:145-147.

Price. K. R., P. J. Mitchell, and D. R. Dahl. 1986. Environmental Monitoring Procedures, Earth Sciences Department. PNL-MA-580, Pacific Northwest Laboratory, Richland, Washington. 
Appendix A

Summary of Unreported Soil Sampling Results 


\section{Appendix A}

\section{Summary of Unreported Soil Sampling Results}

Additional results were found in historical records for the locations and years listed below. None of these previously unreported results was noted to be extraordinary.

\section{A.1 Summary of Unreported Soil Sampling Results for 1970}

A. Samples were collected northeast of the Jersey Nuclear uranium fuel manufacturing plant (currently, Siemens Power Corporation) on November 17, 1970. Samples were analyzed for total Pu (photographic film-track method) and U at U.S. Testing Co., Inc.

1. Sample No. 1: $\mathrm{Pu}=<0.5 \mathrm{~d} / \mathrm{m}$ per $5 \mathrm{~g} ; \mathrm{U}=1.26 \mathrm{ug}$ per $5 \mathrm{~g}$

2. Sample No. 2: $\mathrm{Pu}=<0.5 \mathrm{~d} / \mathrm{m}$ per $5 \mathrm{~g}$; $\mathrm{U}=1.03$ ug per $5 \mathrm{~g}$

(Detection limits: $\mathrm{Pu}=0.5 \mathrm{~d} / \mathrm{m} ; \mathrm{U}=3.0 \mathrm{E}-3 \mathrm{ug}$ )

Note: $\mathrm{d} / \mathrm{m}=$ nuclear disintegrations (film-tracks) per minute, $2.22 \mathrm{~d} / \mathrm{m}=1 \mathrm{pCi}$.

B. Composite samples were collected jointly with the Atomic Energy Commission (AEC) Division of Compliance, Region V, on November 18 and 19, 1970 and analyzed by alpha spectrometry at the AEC Idaho Health Services Laboratory. Five individual surface soil samples, 4 inches $(10 \mathrm{~cm})$ in diameter and 1.5 inches $(3.8 \mathrm{~cm})$ deep, were combined to form a composite sample for analysis. The samples were dried and passed through a 35 mesh screen before analysis:

1. Junction Byers Landing spillway and Road 68

$\mathrm{Pu}-239,240=0.058 \pm 0.005 \mathrm{~d} / \mathrm{m}$ per g

2. $700 \mathrm{ft}$ east of sample number 1 (toward Byers Landing 614 Building);

$\mathrm{Pu}-239,240=0.063 \pm 0.005 \mathrm{~d} / \mathrm{m}$ per $\mathrm{g}$

3. $1400 \mathrm{ft}$ east of sample number 2

$\mathrm{Pu}-239,240=0.006 \pm 0.002 \mathrm{~d} / \mathrm{m}$ per g

4. Byers Landing 614 Building (air sampling station)

Pu-239,240 $=0.047 \pm 0.004 \mathrm{~d} / \mathrm{m}$ per g

5. Composite background sample (North Richland, Ringold, Berg Ranch,

3.3 miles west of Yakima Barricade, and Benton City)

$\mathrm{Pu}-239,240=0.040 \pm 0.004 \mathrm{~d} / \mathrm{m}$ per $\mathrm{g}$ 
Note: $\mathrm{d} / \mathrm{m}=$ nuclear disintegrations per minute, $2.22 \mathrm{~d} / \mathrm{m}=1 \mathrm{pCi}$

These results, and results obtained by PNNL and U.S. Testing Co., Inc. were compared and reported to the AEC and Hanford Site contractors in the spring of 1971.(a) The PNNL and U.S. Testing Co., Inc. results were also reported at the Los Alamos symposium (Corley et al. 1971).

\section{A.2 Summary of Unreported Soil Sampling Results for 1971}

A. Samples collected as part of a pre-operational survey at FFTF included ten soil samples from four locations. Soil was collected at each location from the surface 0.5 inch (sample " $A$ ") and the next 0.5 inch (sample "B") on February 8, 1971. The samples were analyzed by U.S. Testing Co., Inc. for $\mathrm{Sr}-90$ and total Pu (photographic film-track method).

Sample 1-A: $\mathrm{Sr}-90=1.36 \mathrm{E}-1 \mathrm{pCi} / \mathrm{g}$ (dry wt); $\mathrm{Pu}=<0.0025 \mathrm{pCi} / \mathrm{g}$ (dry wt)

Sample 1-B: Sr-90 = <3.8 E-3 pCi/g (dry wt); $\mathrm{Pu}=0.004 \mathrm{pCi} / \mathrm{g}$ (dry wt)

Sample 2-A: Sr-90 = $1.59 \mathrm{E}-1 \mathrm{pCi} / \mathrm{g}$ (dry wt); $\mathrm{Pu}=0.005 \mathrm{pCi} / \mathrm{g}$ (dry wt)

Sample 2-B: $\mathrm{Sr}-90=1.05 \mathrm{E}-1 \mathrm{pCi} / \mathrm{g}$ (dry wt); $\mathrm{Pu}=0.030 \mathrm{pCi} / \mathrm{g}$ (dry wt)

Sample 3-A: $\mathrm{Sr}-90=3.92 \mathrm{E}-1 \mathrm{pCi} / \mathrm{g}$ (dry wt); $\mathrm{Pu}=0.024 \mathrm{pCi} / \mathrm{g}$ (dry wt)

Sample 3-A: (repeat sample collected 4-11-71) $\mathrm{Pu}=0.034 \mathrm{pCi} / \mathrm{g}$ (dry wt)

Sample 3-A: (repeat sample collected 4-11-71) $\mathrm{Pu}=0.050 \mathrm{pCi} / \mathrm{g}$ (dry wt)

Sample 3-B: $\mathrm{Sr}-90=1.79 \mathrm{E}-1 \mathrm{pCi} / \mathrm{g}($ dry wt); $\mathrm{Pu}=0.100 \mathrm{pCi} / \mathrm{g}$ (dry wt)

Sample 4-A: $\mathrm{Sr}-90=1.43 \mathrm{E}-1 \mathrm{pCi} / \mathrm{g}$ (dry wt); $\mathrm{Pu}=0.015 \mathrm{pCi} / \mathrm{g}$ (dry wt)

Sample 4-B: $\mathrm{Sr}-90=<2.3 \mathrm{E}-2 \mathrm{pCi} / \mathrm{g}$ (dry wt); $\mathrm{Pu}=0.012 \mathrm{pCi} / \mathrm{g}$ (dry wt)

Sample 4-B: (duplicate aliquot) $\mathrm{Pu}=0.008 \mathrm{pCi} / \mathrm{g}$ (dry wt)

Note E-1: an exponent notation where $1.36 \mathrm{E}-1$ equals 0.136

B. Samples collected as part of a pre-operational survey at the 331 Building included soil samples collected from three locations. The samples were collected on February 17, 1971 and submitted to U.S. Testing Co., Inc. for total Sr, total $\mathrm{Pu}$ (photographic film-track method), and $\mathrm{U}$ analyses.

Sample \#1: Total Sr $=8.70 \mathrm{E}-1 \mathrm{pCi} / \mathrm{g}$ (dry wt)

$\mathrm{Pu}=4.80 \mathrm{E}-1 \mathrm{pCi} / \mathrm{g}$ (dry wt)

$\mathrm{U}=3.50 \mathrm{E}+0 \mathrm{ug} / 5 \mathrm{~g}$ (dry wt)

Sample \#1: (repeat sample 4-11-71)

$\mathrm{Pu}=<2.81 \mathrm{E}-3 \mathrm{pCi} / \mathrm{g}$ (dry wt)

(a) PNNL Letters, from J. P. Corley to AEC, ARHCO, WADCO, and DUN, Plutonium in Soil Results - November 1970, April and May 1971. 
Sample \#2: Total Sr $=3.64 \mathrm{E}-1 \mathrm{pCi} / \mathrm{g}$ (dry wt)

$$
\begin{aligned}
& \mathrm{Pu}=<1.03 \mathrm{E}-2 \mathrm{pCi} / \mathrm{g} \text { (dry wt) } \\
& \mathrm{U}=3.35 \mathrm{E}+0 \mathrm{ug} / 5 \mathrm{~g} \text { (dry wt) }
\end{aligned}
$$

Sample \#3: Total Sr $=1.12 \mathrm{E}-1 \mathrm{pCi} / \mathrm{g}$ (dry wt)

$$
\begin{aligned}
& \mathrm{Pu}=<7.33 \mathrm{E}-3 \mathrm{pCi} / \mathrm{g} \text { (dry wt) } \\
& \mathrm{U}=1.95 \mathrm{E}+0 \mathrm{ug} / 5 \mathrm{~g} \text { (dry wt) }
\end{aligned}
$$

C. A sample from the Wahluke Slope was delivered to U.S. Testing Co., Inc. on August 20, 1971 for gamma scan (Cs-137), Sr-90, and Pu (photographic film-track method) analyses. The sample was made up from a composite of four samples collected from the "Wahluke Slope across the River from $100-\mathrm{K}$ and 100-N Areas." Records did not indicate if results were based on dry weight, but results usually were reported on a dry weight basis.

Wahluke Slope Sample; Cs-137 = 9.34 E-1 pCi/g

$$
\begin{aligned}
& \mathrm{Sr}-90=9.53 \mathrm{E}-1 \mathrm{pCi} / \mathrm{g} \\
& \mathrm{Pu}=1.63 \mathrm{E}-1 \mathrm{pCi} / \mathrm{g}
\end{aligned}
$$

D. Five additional offsite soil samples were collected in September 1971 and submitted to U.S. Testing Co., Inc. for gamma scan (Cs-137), Sr-90, and Pu analyses. Pu analyses either were not completed or results were not recorded in the historical record. Records did not indicate if the results listed below were based on dry weight, but results usually were reported on a dry weight basis.

Berg Ranch (near air sample station)

$$
\begin{aligned}
& \mathrm{Cs}-137=1.69 \mathrm{pCi} / \mathrm{g} \\
& \mathrm{Sr}-90=0.51 \mathrm{pCi} / \mathrm{g}
\end{aligned}
$$

West Intersection of State Route 24 and Plant Boundary

$$
\begin{aligned}
& \mathrm{Cs}-137=0.22 \mathrm{pCi} / \mathrm{g} \\
& \mathrm{Sr}-90=0.75 \mathrm{pCi} / \mathrm{g}
\end{aligned}
$$

North Side Vernita Bridge

$$
\begin{aligned}
& \mathrm{Cs}-137=0.36 \mathrm{pCi} / \mathrm{g} \\
& \mathrm{Sr}-90=0.17 \mathrm{pCi} / \mathrm{g}
\end{aligned}
$$

FFTF Soil Sampling Location No. 4

$$
\begin{aligned}
& \mathrm{Cs}-137=0.21 \mathrm{pCi} / \mathrm{g} \\
& \mathrm{Sr}-90=0.09 \mathrm{pCi} / \mathrm{g}
\end{aligned}
$$

331 Building Soil Sampling Location No. 1

$$
\begin{aligned}
& \mathrm{Cs}-137=0.67 \mathrm{pCi} / \mathrm{g} \\
& \mathrm{Sr}-90=1.06 \mathrm{pCi} / \mathrm{g}
\end{aligned}
$$




\section{A.3 Summary of Unreported Soil Sampling Results for 1972}

A. A trip log dated April 6, 1972 and a U.S. Testing Co., Inc. Environmental Monitoring Analysis Report (results report) indicated the collection and analysis of the samples listed below. Analytical techniques were not recorded in the historical record. However, alpha spectrometry must have been used because plutonium isotopes were reported. Results are probably on a dry sample weight basis.

100-F River Bank

Cs-137 = $1.78 \mathrm{E}-1 \mathrm{pCi} / \mathrm{g} ; \mathrm{Sr}-90=9.11 \mathrm{E}-2 \mathrm{pCi} / \mathrm{g}$

$\mathrm{Pu}-238=6.00 \mathrm{E}-3 \mathrm{pCi} / \mathrm{g} ; \mathrm{Pu}-239,240=2.00 \mathrm{E}-3 \mathrm{pCi} / \mathrm{g}$

Berg Ranch

Cs-137 $=9.61 \mathrm{E}-1 \mathrm{pCi} / \mathrm{g} ; \mathrm{Sr}-90=5.00 \mathrm{E}-1 \mathrm{pCi} / \mathrm{g}$

$\mathrm{Pu}-238=2.00 \mathrm{E}-3 \mathrm{pCi} / \mathrm{g} ; \mathrm{Pu}-239,240=9.00 \mathrm{E}-3 \mathrm{pCi} / \mathrm{g}$

Vernita (Bridge)

$\mathrm{Cs}-137=1.71 \mathrm{E}-1 \mathrm{pCi} / \mathrm{g} ; \mathrm{Sr}-90=8.66 \mathrm{E}-2 \mathrm{pCi} / \mathrm{g}$

$\mathrm{Pu}-238=1.00 \mathrm{E}-3 \mathrm{pCi} / \mathrm{g} ; \mathrm{Pu}-239,240=0.00 \mathrm{E}-3 \mathrm{pCi} / \mathrm{g}$

Above Savage Island

Cs- $137=1.58 \mathrm{E}-0 \mathrm{pCi} / \mathrm{g} ; \mathrm{Sr}-90=2.65 \mathrm{E}-1 \mathrm{pCi} / \mathrm{g}$

$\mathrm{Pu}-238=2.00 \mathrm{E}-3 \mathrm{pCi} / \mathrm{g} ; \mathrm{Pu}-239,240=8.00 \mathrm{E}-3 \mathrm{pCi} / \mathrm{g}$

Hanford (townsite) River Bank

Cs-137 $=5.68 \mathrm{E}-1 \mathrm{pCi} / \mathrm{g} ; \mathrm{Sr}-90=1.48 \mathrm{E}-1 \mathrm{pCi} / \mathrm{g}$

Pu-238 = 3.00 E-3 pCi/g; Pu-239,240 = 6.00 E-3 pCi/g

Hanford (townsite) 1/4 Mile Upstream

Cs-137 $=0.00 \mathrm{E}-0 \mathrm{pCi} / \mathrm{g} ; \mathrm{Sr}-90=1.37 \mathrm{E}-1 \mathrm{pCi} / \mathrm{g}$

$\mathrm{Pu}-238=4.00 \mathrm{E}-3 \mathrm{pCi} / \mathrm{g} ; \mathrm{Pu}-239,240=0.00 \mathrm{E}-3 \mathrm{pCi} / \mathrm{g}$

100-F Flat

Cs-137 = 2.01 E-0 pCi/g; Sr-90 = $1.03 \mathrm{E}-0 \mathrm{pCi} / \mathrm{g}$

$\mathrm{Pu}-238=5.00 \mathrm{E}-3 \mathrm{pCi} / \mathrm{g} ; \mathrm{Pu}-239,240=2.20 \mathrm{E}-2 \mathrm{pCi} / \mathrm{g}$

C.P. 21 (approx. 3 miles west of Berg Ranch at wasteway)

$\mathrm{Cs}-137=2.53 \mathrm{E}-1 \mathrm{pCi} / \mathrm{g} ; \mathrm{Sr}-90=1.72 \mathrm{E}-1 \mathrm{pCi} / \mathrm{g}$

$\mathrm{Pu}-238=2.00 \mathrm{E}-3 \mathrm{pCi} / \mathrm{g} ; \mathrm{Pu}-239,240=5.00 \mathrm{E}-3 \mathrm{pCi} / \mathrm{g}$

C.P. 24 (Wahluke Slope approx. 3 miles north of Hanford townsite)

Cs-137 = 9.65 E-1 pCi/g; Sr-90 = 5.70 E-1 pCi/g

$\mathrm{Pu}-238=4.00 \mathrm{E}-3 \mathrm{pCi} / \mathrm{g} ; \mathrm{Pu}-239,240=1.20 \mathrm{E}-2 \mathrm{pCi} / \mathrm{g}$ 
Wash (location unknown)

$$
\begin{aligned}
& \mathrm{Cs}-137=1.15 \mathrm{E}-0 \mathrm{pCi} / \mathrm{g} ; \mathrm{Sr}-90=7.48 \mathrm{E}-1 \mathrm{pCi} / \mathrm{g} \\
& \mathrm{Pu}-238=5.00 \mathrm{E}-3 \mathrm{pCi} / \mathrm{g} ; \mathrm{Pu}-239,240=1.20 \mathrm{E}-2 \mathrm{pCi} / \mathrm{g}
\end{aligned}
$$

South End of Locke Island

$$
\begin{aligned}
& \mathrm{Cs}-137=9.97 \mathrm{E}-1 \mathrm{pCi} / \mathrm{g} ; \mathrm{Sr}-90=3.27 \mathrm{E}-1 \mathrm{pCi} / \mathrm{g} \\
& \mathrm{Pu}-238=1.00 \mathrm{E}-3 \mathrm{pCi} / \mathrm{g} ; \mathrm{Pu}-239,240=5.00 \mathrm{E}-3 \mathrm{pCi} / \mathrm{g}
\end{aligned}
$$

B. A copy of a results sheet from U.S. Testing Co., Inc. dated May 30, 1972, showed data for three soil samples and one mud sample from "Honey Hill Pond" (a.k.a. West Lake). Although instructions to U.S. Testing Co., Inc. indicated a gamma scan (Cs-137), Sr-90, and $\mathrm{Pu}$ analyses, all results were not located in the historical record. Neither the cover letter nor the results sheet indicated if the data were on a dry weight basis. However, results were usually reported on a dry weight basis.

1. $1 / 4$ mile E of Honey Hill Pond

$\mathrm{Cs}-137=7.56 \mathrm{E}-1 \mathrm{pCi} / \mathrm{g} ; \mathrm{Sr}-90=($ no record $)$

Pu-238 = 1.2 E-3 pCi/g; Pu-23.9,240 = 1.57 E-2 pCi/g

2. Midway Between 200-E Area and Honey Hill Pond

$\mathrm{Cs}-137=2.04 \mathrm{E}-0 \mathrm{pCi} / \mathrm{g} ; \mathrm{Sr}-90=$ (no record)

$\mathrm{Pu}-238=2.6 \mathrm{E}-3 \mathrm{pCi} / \mathrm{g} ; \mathrm{Pu}-239,240=3.72 \mathrm{E}-2 \mathrm{pCi} / \mathrm{g}$

3. Honey Hill Bank Soil Composite

Cs-137 $=6.85 \mathrm{E}-1 \mathrm{pCi} / \mathrm{g} ; \mathrm{Sr}-90=$ (no record)

Pu-238 = 1.1 E-3 pCi/g; Pu-239,240 = 1.05 E-2 pCi/g

4. Honey Hill Mud

Cs-137 = 1.49 E-0 pCi/g; Sr-90 = $1.69 \mathrm{E}-1 \mathrm{pCi} / \mathrm{g}$

$\mathrm{Pu}-238=$ (no record); $\mathrm{Pu}-239,240=$ (no record)

C. Three soil samples were submitted to U.S. Testing Co., Inc. for gamma scan (Cs-137) and Sr-90 analyses on November 8, 1972. Neither the cover letter nor the result sheet indicated if the data were on a dry weight basis. However, results were usually reported on a dry weight basis.

1. Intersection of Highway $4 \mathrm{~S}$ and Highway $11 \mathrm{~A}$

$\mathrm{Cs}-137=2.02 \mathrm{E}-0 \mathrm{pCi} / \mathrm{g} ; \mathrm{Sr}-90=4.47 \mathrm{E}-1 \mathrm{pCi} / \mathrm{g}$

2. North of 200 ENC (200-East Area, North Central)

$\mathrm{Cs}-137=1.43 \mathrm{E}-0 \mathrm{pCi} / \mathrm{g} ; \mathrm{Sr}-90=1.28 \mathrm{E}-1 \mathrm{pCi} / \mathrm{g}$

3. At Test well 699-31-53B (across Highway 4S, south of 200-E Area)

$\mathrm{Cs}-137=6.96 \mathrm{E}-0 \mathrm{pCi} / \mathrm{g} ; \mathrm{Sr}-90=1.68 \mathrm{E}+1 \mathrm{pCi} / \mathrm{g}$ 


\section{Appendix B}

\section{Results for 20 Long-Term Soil Sampling Locations}




\section{Appendix B}

\section{Results for 20 Long-Term Soil Sampling Locations}

Listed in this Appendix are the 20 long-term soil sampling locations and two supplemental locations discussed in Section 3.0, "Sampling Locations." The results shown for each location represent all of the data in the PNNL computer data base for Sr-90, Cs-137, Pu, Pu-238, and Pu-239,240 for the years 1971 through 1994 (the last year of sampling). The numbers under the column "Depth inches" mean the following:

01 or surface layer to 1 inch depth

12 or subsurface layer 1 inch to 2 inch depth

24 or subsurface layer 2 inch to 4 inch depth

48 or subsurface layer 4 inch to 8 inch depth

812 or subsurface layer 8 inch to 12 inch depth.

\section{Onsite Sampling Locations}

Location Name

- Wahluke Slope No. 2

- NE FFTF

- Yakima Barricade

- FFTF CP 62

- E of 200-W Area

- Wye Barricade

- 200 ENC

- 200 ESE

- Hanford Townsite

- Prosser Barricade

- SE FFTF

- ALE

- ERC

\section{Offsite Sampling Locations}

Location Name

- Benton City

- Sunnyside

- Harris Farm

- Byers Landing

- Sagemore

- Fir Road

- Taylor Flats No. 2

- Ringold

- Berg Ranch

B.1 
Table B.1. Onsite Sampling Locations

\begin{tabular}{|c|c|c|c|c|c|c|c|c|c|c|c|c|c|}
\hline Sample Site & $\begin{array}{l}\text { Dep } \\
\text { inch }\end{array}$ & & Date & Constituent & $\begin{array}{l}\text { Result } \\
\text { pCi/g }\end{array}$ & $\begin{array}{l}\text { Counting } \\
\text { Error }\end{array}$ & $\begin{array}{c}\text { Analytical } \\
\text { Error } \\
\end{array}$ & Sample Site & $\begin{array}{l}\text { Dep } \\
\text { inch }\end{array}$ & Date & Constituent & $\begin{array}{l}\text { Result } \\
\mathrm{pC} \text { Ci/g }\end{array}$ & $\begin{array}{c}\text { Counting } \\
\text { Error }\end{array}$ \\
\hline WAHLUKE & 1 & 2 & $09 / 29 / 71$ & SR-90 & 0.092 & 0 & & WAHLUKE & 0 & $105 / 31 / 84$ & PU-239,240 & 0.0061 & 0.00287 \\
\hline SLOPE NO. 2 & 0 & 1 & $09 / 29 / 71$ & SR-90 & 0.183 & 0 & & SLOPE NO. 2 & 0 & $106 / 12 / 85$ & PU-239,240 & 0.0087 & 0.00146 \\
\hline & 1 & 2 & $10 / 25 / 72$ & SR-90 & 0.131 & 0 & & (contd) & 0 & $105 / 02 / 86$ & PU-239,240 & 0.0055 & 0.000949 \\
\hline & & 1 & $10 / 25 / 72$ & SR-90 & 0.295 & 0 & & & 0 & $105 / 26 / 87$ & PU-239,240 & 0.0029 & 0.000758 \\
\hline & 0 & 1 & $10 / 25 / 73$ & SR-90 & 0.374 & 0.0054 & & & 0 & $106 / 10 / 88$ & PU-239,240 & 0.0067 & 0.000923 \\
\hline & 0 & 1 & $09 / 23 / 74$ & SR-90 & 0.0154 & 0 & & & 0 & $105 / 05 / 89$ & PU-239,240 & 0.0053 & 0.000784 \\
\hline & 0 & 1 & $08 / 19 / 75$ & SR-90 & 0.1 & 0 & & & 0 & $10 / 03 / 90$ & PU-239,240 & 0.0071 & 0.00098 \\
\hline & 0 & 1 & $08 / 09 / 76$ & SR-90 & 0.0309 & 0 & & & 0 & $106 / 09 / 93$ & PU-239,240 & 0.004 & 0.000813 \\
\hline & 0 & 1 & $06 / 14 / 77$ & SR-90 & 0.0167 & 0.0034 & & & l & $209 / 29 / 71$ & PU & 0.0035 & 0 \\
\hline & 0 & 1 & $08 / 09 / 78$ & SR-90 & 0.0114 & $0.00: 34$ & & & 0 & $109 / 29 / 71$ & PU & 0.0045 & 0 \\
\hline & 0 & 1 & $09 / 13 / 79$ & SR-90 & 0.0958 & 0.0067 & & & 1 & $210 / 25 / 72$ & PU & 0.0028 & 0 \\
\hline & 0 & 1 & $08 / 06 / 80$ & SR-90 & 0.309 & 0.0 .14 & & & 0 & $1 \quad 10 / 25 / 72$ & PU & 0.01 & 0 \\
\hline & 0 & 1 & $08 / 11 / 81$ & SR-90 & 0.0889 & 0.0022 & & & & & & & \\
\hline & 0 & 1 & $08 / 30 / 82$ & SR-90 & 0.0992 & 0.0349 & & YAKIMA & 0 & $109 / 29 / 71$ & SR-90 & 0.159 & 0 \\
\hline & 0 & 1 & $08 / 26 / 83$ & SR-90 & 0.646 & 0.0232 & & BARRICADE & 1 & $209 / 29 / 71$ & SR-90 & 0.159 & 0 \\
\hline & 0 & 1 & $05 / 31 / 84$ & SR-90 & 0.161 & 0.0 .17 & 0.0355 & & 1 & $210 / 25 / 72$ & SR-90 & 0.107 & 0 \\
\hline & 0 & 1 & $06 / 12 / 85$ & SR-90 & 0.207 & 0.0227 & 0.0464 & & 0 & $110 / 25 / 72$ & SR-90 & 0.117 & 0 \\
\hline & 0 & 1 & $05 / 02 / 86$ & SR-90 & 0.0983 & 0.006 .56 & 0.0205 & & 0 & $110 / 25 / 73$ & SR-90 & 0.166 & 0.0038 \\
\hline & 0 & 1 & $05 / 26 / 87$ & SR-90 & 0.0747 & 0.0101 & 0.0216 & & 0 & $109 / 23 / 74$ & SR-90 & 0.0131 & 0 \\
\hline & 0 & 1 & $06 / 10 / 88$ & SR-90 & 0.093 & 0.00681 & 0.0185 & & 0 & $108 / 19 / 75$ & SR-90 & 0.121 & 0 \\
\hline & 0 & 1 & $05 / 05 / 89$ & SR-90 & 0.0658 & 0.00552 & 0.0144 & & 0 & I $08 / 10 / 76$ & SR-90 & 0.152 & 0 \\
\hline & 0 & 1 & $10 / 03 / 90$ & SR-90 & 0.0628 & 0.00766 & 0.0139 & & 0 & l $06 / 14 / 77$ & SR-90 & 0.013 & 0.0034 \\
\hline & 0 & 1 & $06 / 09 / 93$ & SR-90 & 0.0507 & 0.006 .24 & 0.0117 & & 0 & $108 / 08 / 78$ & SR-90 & 0.0095 & 0.003 \\
\hline & 1 & 2 & $09 / 29 / 71$ & CS-137 & 0.256 & 0 & & & 0 & $109 / 11779$ & SR-90 & 0.229 & 0.012 \\
\hline & 0 & 1 & $09 / 29 / 71$ & CS-137 & 0.468 & 0 & & & 0 & $108 / 04 / 80$ & SR-90 & 0.016 & 0.007 \\
\hline & 1 & 2 & $10 / 25 / 72$ & CS-137 & 0.158 & 0 & & & 0 & $108 / 11 / 81$ & SR-90 & 0.223 & 0.023 \\
\hline & 0 & 1 & $10 / 25 / 72$ & CS-137 & 0.724 & 0 & & & 0 & $108 / 17 / 82$ & SR-90 & 0.0904 & 0.00337 \\
\hline & 0 & 1 & $10 / 25 / 73$ & CS-137 & 1.01 & 0 & & & 0 & I $08 / 11 / 83$ & SR-90 & 0.591 & 0.0226 \\
\hline & 0 & 1 & $09 / 23 / 74$ & CS-137 & 0.229 & 0 & & & 0 & $105 / 24 / 84$ & SR-90 & 0.134 & 0.0173 \\
\hline & 0 & 1 & $08 / 19 / 75$ & CS-137 & 0.313 & 0 & & & 0 & $106 / 06 / 85$ & SR-90 & 0.537 & 0.0293 \\
\hline & 0 & 1 & $08 / 09776$ & CS-137 & 0.288 & 0 & & & 0 & $105 / 07 / 87$ & SR-90 & 0.0639 & 0.0121 \\
\hline & 0 & 1 & $06 / 14 / 77$ & CS-137 & 0.177 & 0.043 & & & 0 & $105 / 25 / 88$ & SR-90 & 0.0687 & 0.00617 \\
\hline & 0 & I & $08 / 09 / 78$ & CS-137 & 0.327 & 0.055 & & & 0 & I $05 / 05 / 89$ & SR-90 & 0.129 & 0.00826 \\
\hline & 0 & 1 & $09 / 13 / 79$ & CS-137 & 0.463 & 0.064 & & & 0 & $107 / 31 / 91$ & SR-90 & 0.143 & 0.0121 \\
\hline & 0 & 1 & $08 / 06 / 80$ & CS-137 & 0.349 & 0.0152 & & & 0 & $106 / 09 / 93$ & SR-90 & 0.0954 & 0.0157 \\
\hline & 0 & 1 & $08 / 11 / 81$ & CS-137 & 0.101 & 0.0118 & & & 0 & $109 / 29 / 71$ & CS-137 & 0.174 & 0 \\
\hline & 0 & 1 & $03 / 30 / 82$ & CS-137 & 0.342 & 0.0687 & & & 1 & $209 / 30 / 71$ & CS-137 & 0 & 0 \\
\hline & 0 & 1 & $08 / 26 / 83$ & CS-137 & 0.252 & 0.02 .91 & & & 0 & $110 / 25 / 72$ & CS-137 & 0.258 & 0 \\
\hline & 0 & 1 & $05 / 31 / 84$ & CS-137 & 0.288 & 0.0284 & 0.0332 & & 1 & $210 / 25 / 72$ & CS-137 & 0.357 & 0 \\
\hline & 0 & I & $06 / 12 / 85$ & CS-137 & 0.474 & 0.0472 & 0.0551 & & 0 & I $10 / 25 / 73$ & CS-137 & 0.586 & 0 \\
\hline & 0 & 1 & $05 / 02 / 86$ & CS-137 & 0.303 & 0.0133 & 0.0448 & & 0 & $109 / 23 / 74$ & CS-137 & 0.11 & 0 \\
\hline & 0 & 1 & $05 / 26 / 87$ & CS- 137 & 0.159 & 0.0316 & 0.0353 & & 0 & $108 / 19 / 75$ & CS-137 & 0.095 & 0 \\
\hline & 0 & 1 & $06 / 10 / 88$ & CS-137 & 0.222 & 0.0334 & 0.0401 & & 0 & $108 / 10 / 76$ & CS-137 & 0.392 & 0 \\
\hline - & 0 & 1 & $05 / 05 / 89$ & CS -137 & 0.25 & 0.0304 & 0.0394 & & 0 & $106 / 14 / 77$ & CS- 137 & 0.616 & 0.073 \\
\hline & 0 & 1 & $10 / 03 / 90$ & CS- 137 & 0.224 & 0.029 & 0.0366 & & 0 & $108 / 08 / 78$ & CS-137 & 0.272 & 0.051 \\
\hline & 0 & 1 & $06 / 09 / 93$ & CS-137 & 0.201 & 0.02 .65 & 0.0333 & & 0 & $109 / 11 / 79$ & CS- 137 & 0.817 & 0.083 \\
\hline & 1 & 2 & $09 / 29 / 71$ & PU-238 & 0.003 & 0 & & & 0 & $108 / 04 / 80$ & CS-137 & 0.773 & 0.074 \\
\hline & 0 & 1 & $09 / 29 / 71$ & PU-238 & 0.004 & 0 & & & 0 & $108 / 11 / 81$ & CS-137 & 0.314 & 0.027 \\
\hline & 0 & 1 & $10 / 25 / 72$ & PU-238 & 0 & 0 & & & 0 & $108 / 17 / 82$ & CS-137 & 0.415 & 0.0362 \\
\hline & 1 & 2 & $10 / 25 / 72$ & PU-238 & 0.00627 & 0 & & & 0 & $108 / 11 / 83$ & CS-137 & 0.697 & 0.0535 \\
\hline & 0 & 1 & $10 / 25 / 73$ & PU-238 & 0.00121 & 0.003 & & & 0 & $105 / 24 / 84$ & CS-137 & 0.102 & 0.0275 \\
\hline & 0 & 1 & $09 / 23 / 74$ & PU-238 & 0.000384 & 0 & & & 0 & $106 / 06 / 85$ & CS-137 & 1.07 & 0.0661 \\
\hline & 0 & 1 & $08 / 19 / 75$ & PU-238 & 0.000547 & 0 & & & 0 & $105 / 07 / 87$ & CS-137 & 0.0806 & 0.0203 \\
\hline & 0 & 1 & $08 / 09 / 76$ & PU-238 & 0.00636 & 0 & & & 0 & $105 / 25 / 88$ & CS-137 & 0.0784 & 0.0225 \\
\hline & 0 & i & $06 / 14 / 77$ & PU-238 & 0.00109 & 0.00111 & & & 0 & $105 / 05 / 89$ & CS-137 & 0.539 & 0.0392 \\
\hline & 0 & 1 & $08 / 09 / 78$ & PU-238 & -0.000499 & 0.00118 & & & 0 & $107 / 31 / 91$ & CS-137 & 0.362 & 0.0329 \\
\hline & 0 & 1 & $09 / 13 / 79$ & PU-238 & 0.000112 & 0.006197 & & & 0 & $106 / 09 / 93$ & CS-137 & 0.3 & 0.027 \\
\hline & 0 & $i$ & $08 / 06 / 80$ & PU-238 & 0.000679 & $0.00(184$ & & & 1 & $209 / 29 / 71$ & PU-238 & 0.003 & 0 \\
\hline & 0 & 1 & $08 / 11 / 81$ & PU-238 & -0.000616 & 0.00127 & & & 0 & $109 / 29 / 71$ & PU-238 & 0.004 & 0 \\
\hline & 0 & 1 & $08 / 30 / 82$ & PU-238 & -0.000356 & $0.0008: 26$ & & & 1 & $210 / 25 / 72$ & PU-238 & 0 & 0 \\
\hline & 0 & $i$ & $08 / 26 / 83$ & PU-238 & 0.00122 & $0.0008: 35$ & & & 0 & $110 / 25 / 72$ & PU-238 & 0.0033 & 0 \\
\hline & 0 & 1 & $05 / 31 / 84$ & PU-238 & 0,000338 & 0.0006776 & 0.00068 & & 0 & $110 / 25 / 73$ & PU-238 & 0.0012 & 0.003 \\
\hline & 0 & 1 & $06 / 12 / 85$ & PU-238 & 0.000317 & $0.0003,68$ & 0.00037 & & 0 & $109 / 23 / 74$ & PU-238 & 0.0007 & 0 \\
\hline & 0 & 1 & $05 / 02 / 86$ & PU-238 & 0 & $0.0002: 22$ & 0.000222 & & 0 & $108 / 19 / 75$ & PU-238 & 0.0002 & 0 \\
\hline & 0 & 1 & $05 / 26 / 87$ & PU-238 & 0.0000473 & 0.000141 & 0.000149 & & 0. & $108 / 10 / 76$ & PU-238 & 0.0008 & 0 \\
\hline & 0 & 1 & $06 / 10 / 88$ & PU-238 & 0.000109 & 0.000153 & 0.000155 & & 0 & $106 / 14 / 77$ & PU-238 & 0.0045 & 0.0027 \\
\hline & 0 & 1 & $05 / 05 / 89$ & PU-238 & 0.000129 & 0.000154 & 0.000155 & & 0 & $108 / 08 / 78$ & PU-238 & -0.0009 & 0.0022 \\
\hline & 0 & 1 & $10 / 03 / 90$ & PU-238 & 0.000593 & $0.0003 ; 58$ & 0.000364 & & 0 & $109 / 11 / 79$ & PU-238 & -0.0009 & 0.00055 \\
\hline & 0 & 1 & $06 / 09 / 93$ & PU-238 & 0.000147 & 0.000163 & 0.000165 & & 0 & $108 / 04 / 80$ & PU-238 & 0.0036 & 0.0013 \\
\hline & 1 & 2 & $09 / 29 / 71$ & PU-239,240 & 0.004 & 0 & & & 0 & $108 / 11 / 81$ & PU-238 & 0.0094 & 0.0017 \\
\hline & 0 & 1 & $09 / 29 / 71$ & PU-239,240 & 0.004 & 0 & & & 0 & $108 / 17 / 82$ & PU-238 & $-2 E-05$ & 0.000469 \\
\hline & 1 & 2 & $10 / 25 / 72$ & PU-239,240 & 0.003 & 0 & & & 0 & $108 / 11 / 83$ & PU-238 & 0.0021 & 0.000782 \\
\hline & 0 & 1 & $10 / 25 / 72$ & PU-239,240 & 0.01 & 0 & & & 0 & $105 / 24 / 84$ & PU-238 & $-7 \mathrm{E}-05$ & 0.00014 \\
\hline & 0 & 1 & $10 / 25 / 73$ & PU-239,240 & 0.0231 & 0 & & & 0 & $106 / 06 / 85$ & PU-238 & 0.0003 & 0.000197 \\
\hline & 0 & 1 & $09 / 23 / 74$ & PU-239,240 & 0.0134 & 0 & & & 0 & $105 / 07 / 87$ & PU-238 & $3 E-05$ & 0.000092 \\
\hline & 0 & 1 & $08 / 19 / 75$ & PU-239,240 & 0.00414 & 0 & & & 0 & $105 / 25 / 88$ & PU-238 & 0.0002 & 0.000153 \\
\hline & 0 & 1 & $08 / 09 / 76$ & PU-239,240 & 0.01 & 0 & & & 0 & $105 / 05 / 89$ & PU-238 & 0.0003 & 0.000198 \\
\hline & 0 & 1 & $06 / 14 / 77$ & PU $-239,240$ & 0.00335 & 0.0015 & & & 0 & $107 / 31 / 91$ & PU-238 & 0.0002 & 0.000193 \\
\hline & 0 & 1 & $08 / 09 / 78$ & PU-239,240 & 0.00458 & 0.003 & & & 0 & $106 / 09 / 93$ & PU-238 & 0.0003 & 0.000229 \\
\hline & 0 & 1 & $09 / 13 / 79$ & PU-239,240 & 0.00596 & 0.0022 & & & i & $209 / 29 / 71$ & PU-239,240 & 0.003 & 0 \\
\hline & 0 & 1 & $08 / 06 / 80$ & PU-239,240 & 0.00632 & 0.0016 & & & 0 & $109 / 29 / 71$ & PU-239,240 & 0.005 & 0 \\
\hline & 0 & 1 & $08 / 11 / 81$ & PU-239,240 & 0.00367 & 0.000076 & & & i & $210 / 25 / 72$ & PU-239,240 & 0.005 & 0 \\
\hline & 0 & 1 & $08 / 30 / 82$ & PU-239,240 & 0.00603 & $0.0) 23$ & & & 0 & $110 / 25 / 72$ & PU-239,240 & 0.009 & 0 \\
\hline & 0 & 1 & $08 / 26 / 83$ & PU-239.240 & 0.00956 & 0.00222 & & & 0 & $110 / 25 / 73$ & PU-239.240 & 0.0122 & 0 \\
\hline
\end{tabular}


Table B.1. (contd)

\begin{tabular}{|c|c|c|c|c|c|c|c|c|c|c|c|c|c|}
\hline Sample Site & $\begin{array}{l}\text { Dept } \\
\text { inche }\end{array}$ & & Date & Constituent & $\begin{array}{l}\text { Result } \\
\text { pCi/g }\end{array}$ & $\begin{array}{l}\text { Counting } \\
\text { Error }\end{array}$ & $\begin{array}{c}\text { Anslytical } \\
\text { Error }\end{array}$ & Sample Site & $\begin{array}{l}\text { Dep } \\
\text { inch }\end{array}$ & & Date & Constituent & $\begin{array}{l}\text { Result } \\
\mathrm{pC} / \mathrm{q}\end{array}$ \\
\hline YAKMMA & 0 & 1 & $09 / 23 / 74$ & PU-239,240 & 0.00344 & 0 & & E OF $200 \mathrm{~W}$ & 0 & 1 & $0614 / 77$ & PU-239,240 & 0.165 \\
\hline BARRICADE & 0 & 1 & $08 / 19 / 75$ & PU-239,240 & 0.0048 & 0 & & AREA (contd) & 0 & $i$ & $08 / 09 / 78$ & PU-239,240 & 0.561 \\
\hline (contd) & 0 & 1 & $08 / 10 / 76$ & PU $-239,240$ & 0.00572 & 0 & & & 0 & 1 & $09 / 11 / 79$ & PU-239,240 & 0.833 \\
\hline & 0 & 1 & $06 / 14 / 77$ & PU-239,240 & 0.00827 & 0.0033 & & & 0 & 1 & $08 / 04 / 80$ & PU-239,240 & 0.63 \\
\hline & 0 & 1 & $08 / 08 / 78$ & PU-239,240 & 0.0196 & 0.0066 & & & 0 & 1 & $08 / 10 / 81$ & PU-239,240 & 0.42 \\
\hline & 0 & 1 & $09 / 11 / 79$ & PU-239,240 & 0.0045 & 0.002 & & & 0 & 1 & $08 / 30 / 82$ & PU-239,240 & 0.778 \\
\hline & 0 & 1 & $08 / 04 / 80$ & PU-239,240 & 0.017 & 0.0026 & & & 0 & 1 & 08/12/83 & PU-239,240 & 0.831 \\
\hline & 0 & 1 & $08 / 11 / 81$ & PU-239,240 & 0.0177 & 0.0022 & & & 0 & 1 & $05 / 15 / 84$ & PU-239,240 & 0.0737 \\
\hline & 0 & 1 & $08 / 17 / 82$ & PU-239,240 & 0.0106 & 0.00148 & & & 0 & 1 & $05 / 31 / 85$ & PU-239,240 & 0.327 \\
\hline & 0 & 1 & $08 / 11 / 83$ & PU-239,240 & 0.0141 & 0.00204 & & & 0 & 1 & $05 / 01 / 86$ & PU $-239,240$ & 0.337 \\
\hline & 0 & 1 & $05 / 24 / 84$ & PU-239,240 & 0.00157 & 0.00105 & 0.00108 & & 0 & 1 & $05 / 07 / 87$ & PU-239,240 & 0.17 \\
\hline & 0 & 1 & $06 / 06 / 85$ & PU-239,240 & 0.0215 & 0.00154 & 0.00252 & & 0 & 1 & $03 / 31 / 88$ & PU-239,240 & 0.64 \\
\hline & 0 & 1 & $05 / 07 / 87$ & PU-239,240 & 0.00151 & 0.000404 & 0.000434 & & 0 & 1 & $04 / 05 / 88$ & PU-239,240 & 0.707 \\
\hline . & 0 & 1 & $05 / 25 / 88$ & PU-239,240 & 0.00271 & 0.000612 & 0.000677 & & 0 & 1 & $05 / 03 / 89$ & PU-239,240 & 0.53 \\
\hline & 0 & 1 & $05 / 05 / 89$ & PU-239,240 & 0.0114 & 0.00114 & 0.00163 & & 0 & 1 & $10 / 04 / 90$ & PU-239,240 & 0.656 \\
\hline & 0 & 1 & $07 / 31 / 91$ & PU-239,240 & 0.00502 & 0.000938 & 0.00106 & & 0 & 1 & $08 / 13 / 91$ & PU-239,240 & 0.286 \\
\hline & 0 & 1 & $06 / 09 / 93$ & PU-239,240 & 0.00918 & 0.00108 & 0.00144 & & 0 & 1 & $06 / 03 / 93$ & PU-239,240 & 0.283 \\
\hline & 1 & 2 & $09 / 29 / 71$ & PU & 0.003 & 0 & & & 0 & 1 & 08/24/94 & PU-239,240 & 0.391 \\
\hline & 0 & 1 & $09 / 29 / 71$ & PU & 0.009 & 0 & & & & & & & \\
\hline & 0 & 1 & $10 / 25 / 72$ & PU & 0.00475 & 0 & & 200 ENC & 0 & 1 & $06 / 14 / 77$ & SR-90 & 0.0023 \\
\hline & 1 & 2 & $10 / 25 / 72$ & PU & 0.00546 & 0 & & & 0 & $\cdot 1$ & $08 / 10 / 78$ & SR-90 & 0.698 \\
\hline & & & & & & & & & 0 & I & $09 / 11 / 79$ & SR-90 & 0.954 \\
\hline E OF $200 \mathrm{~W}$ & 0 & 1 & $08 / 18 / 75$ & SR-90 & 0.293 & 0 & & & 0 & 1 & $08 / 05 / 80$ & SR-90 & 0.695 \\
\hline AREA & 0 & 1 & $08 / 11 / 76$ & SR-90 & 0.254 & 0 & & & 0 & 1 & $08 / 10 / 81$ & SR-90 & 0.452 \\
\hline & 0 & 1 & $06 / 14 / 77$ & SR-90 & 0.153 & 0.0072 & & & 0 & 1 & $08 / 10 / 81$ & SR-90 & 0.63 \\
\hline & 0 & 1 & $08 / 09 / 78$ & SR-90 & 0.0132 & 0.0032 & & & 0 & 1 & $08 / 30 / 82$ & SR-90 & 0.931 \\
\hline & 0 & 1 & $09 / 11 / 79$ & SR-90 & 1.11 & 0.018 & & & 0 & 1 & $08 / 12 / 83$ & SR-90 & 2.72 \\
\hline & 0 & 1 & $08 / 04 / 80$ & SR-90 & 0.825 & 0.0095 & & & 0 & 1 & $05 / 17 / 84$ & SR-90 & 0.196 \\
\hline & 0 & 1 & $08 / 10 / 81$ & SR-90 & 0.481 & 0.027 & & & 0 & 1 & $05 / 31 / 85$ & SR-90 & 1.18 \\
\hline & 0 & 1 & $08 / 30 / 82$ & SR-90 & 0.477 & 0.105 & & & 0 & 1 & $04 / 30 / 86$ & SR-90 & 0.614 \\
\hline & 0 & 1 & $08 / 12 / 83$ & SR-90 & 2.56 & 0.048 & & & 0 & 1 & $05 / 07 / 87$ & SR-90 & 1.13 \\
\hline & 0 & 1 & $05 / 15 / 84$ & SR-90 & 0.334 & 0.0222 & 0.108 & & 0 & 1 & $03 / 22 / 88$ & SR-90 & 0.774 \\
\hline & 0 & 1 & $05 / 31 / 85$ & SR-90 & 0.605 & 0.0387 & 0.124 & & 0 & 1 & $05 / 02 / 89$ & SR-90 & 0.576 \\
\hline & 0 & 1 & $05 / 01 / 86$ & SR-90 & $0.56 !$ & 0.0143 & 0.103 & & 0 & 1 & $08 / 13 / 91$ & SR-90 & 0.409 \\
\hline & 0 & 1 & $05 / 07 / 87$ & SR-90 & 0.38 & 0.0199 & 0.0997 & & 0 & 1 & $06 / 03 / 93$ & SR-90 & 0.538 \\
\hline & 0 & 1 & $03 / 31 / 88$ & SR-90 & 0.82 & 0.0192 & 0.205 & & 0 & 1 & $08 / 15 / 94$ & SR-90 & 0.703 \\
\hline & 0 & 1 & $04 / 05 / 88$ & SR-90 & 0.606 & 0.0215 & 0.112 & & 0 & 1 & $06 / 14 / 77$ & CS-137 & 28.6 \\
\hline & 0 & 1 & $05 / 03 / 89$ & SR-90 & 0.495 & 0.0169 & 0.0964 & & 0 & 1 & $08 / 10 / 78$ & CS-137 & 1.64 \\
\hline & 0 & 1 & $10 / 04 / 90$ & SR-90 & 2.7 & 0.0714 & 0.488 & & 0 & 1 & $09 / 11 / 79$ & CS-137 & 35.2 \\
\hline & 0 & 1 & $03 / 13 / 91$ & SR-90 & 0.374 & 0.0176 & 0.0712 & & 0 & 1 & $08 / 05 / 80$ & CS-137 & 27.5 \\
\hline & 0 & 1 & $06 / 03 / 93$ & SR-90 & 0.577 & 0.0187 & 0.106 & & 0 & 1 & $08 / 10 / 81$ & CS-137 & 12.4 \\
\hline & 0 & 1 & $08 / 24 / 94$ & SR-90 & 0.0779 & 0.00747 & 0.0164 & & 0 & 1 & $08 / 10 / 81$ & CS-137 & 18.1 \\
\hline & 0 & 1 & $08 / 18 / 75$ & CS-137 & 3.01 & 0 & & & 0 & 1 & $08 / 30 / 82$ & CS-137 & 22.4 \\
\hline & 0 & 1 & $08 / 11 / 76$ & CS-137 & 0.907 & 0 & & & 0 & 1 & $08 / 12 / 83$ & CS-137 & 28.1 \\
\hline & 0 & 1 & $06 / 14 / 77$ & CS-137 & 0.971 & 0.09 & & & 0 & 1 & $05 / 17 / 84$ & CS-137 & 21.2 \\
\hline & 0 & 1 & $08 / 09 / 78$ & CS-137 & 4.2 & 0.18 & & & 0 & 1 & $05 / 31 / 85$ & CS-137 & 22.8 \\
\hline & 0 & 1 & $09 / 11 / 79$ & CS-137 & 3.84 & 0.17 & & & 0 & 1 & $04 / 30 / 86$ & CS-137 & 9.57 \\
\hline & 0 & 1 & $08 / 04 / 80$ & CS-137 & 4.78 & 0.18 & & & 0 & 1 & $05 / 07 / 87$ & CS-137 & 16 \\
\hline & 0 & 1 & $08 / 10 / 81$ & CS-137 & 2.53 & 0.075 & & & 0 & 1 & $03 / 22 / 88$ & CS-137 & 26.1 \\
\hline & 0 & 1 & $08 / 30 / 82$ & CS-137 & 3.21 & 0.101 & & & 0 & 1 & $05 / 02 / 89$ & CS-137 & 17.9 \\
\hline & 0 & 1 & $08 / 12 / 83$ & CS-137 & 5.66 & 0.152 & & & 0 & 1 & $08 / 13 / 91$ & CS-137 & 0.295 \\
\hline & 0 & 1 & $05 / 15 / 84$ & CS-137 & 0.585 & 0.0413 & 0.0542 & & 0 & 1 & $06 / 03 / 93$ & CS-137 & 10.9 \\
\hline & 0 & 1 & $05 / 31 / 85$ & CS-137 & 1.97 & 0.0693 & 0.137 & & 0 & 1 & $08 / 15 / 94$ & CS-137 & 12.3 \\
\hline & 0 & 1 & $05 / 01 / 86$ & CS-137 & 3.08 & 0.0907 & 0.321 & & 0 & 1 & $06 / 14 / 77$ & PU-238 & 0.0092 \\
\hline & 0 & 1 & $05 / 07 / 87$ & CS-137 & 1.3 & 0.0536 & 0.141 & & 0 & 1 & $08 / 10 / 78$ & PU-238 & 0.0012 \\
\hline & 0 & 1 & $03 / 31 / 88$ & CS-137 & 4.73 & 0.0857 & 0.481 & & 0 & 1 & $09 / 11 / 79$ & PUT-238 & 0.0014 \\
\hline & 0 & 1 & $04 / 05 / 88$ & CS-137 & 6.06 & 0.115 & 0.617 & & 0 & 1 & $08 / 05 / 80$ & PU-238 & 0.0017 \\
\hline & 0 & 1 & $05 / 93 / 89$ & CS-137 & 2.98 & 0.0846 & 0.309 & & 0 & 1 & $08 / 10 / 81$ & PU-238 & 0.0003 \\
\hline & 0 & 1 & $10 / 04 / 90$ & CS-137 & 3.86 & 0.105 & 0.4 & & 0 & 1 & $08 / 10 / 81$ & PU-238 & 0.0308 \\
\hline & 0 & 1 & $08 / 13 / 91$ & CS-137 & 1.6 & 0.0647 & 0.173 & & 0 & 1 & $08 / 30 / 82$ & PU-238 & 0.0013 \\
\hline & 0 & 1 & $06 / 03 / 93$ & CS-137 & 1.47 & 0.0447 & 0.154 & & 0 & 1 & $08 / 12 / 83$ & PU-238 & 0.0013 \\
\hline & 0 & 1 & $08 / 24 / 94$ & CS-137 & 0.937 & 0.0688 & 0.116 & & 0 & 1 & $05 / 17 / 84$ & PU-238 & 0.0006 \\
\hline & 0 & 1 & $08 / 18 / 75$ & PU-238 & 0.00514 & 0 & & & 0 & 1 & $05 / 31 / 85$ & PU-238 & 0.0012 \\
\hline & 0 & 1 & $08 / 11 / 76$ & PU-238 & 0.002 & 0 & & & 0 & 1 & $04 / 30 / 86$ & PU-238 & 0.0004 \\
\hline & 0 & 1 & $06 / 14 / 77$ & PU-238 & 0.00865 & 0.0045 & & & 0 & 1 & $05 / 07 / 87$ & PU-238 & 0.0004 \\
\hline & 0 & 1 & $08 / 09 / 78$ & PU-238 & 0.00613 & 0.0024 & & & 0 & 1 & $03 / 22 / 88$ & PU-238 & 0.0017 \\
\hline & 0 & 1 & $09 / 11 / 79$ & PU-238 & 0.00735 & 0.0022 & & & 0 & 1 & $05 / 02 / 89$ & PU.238 & 0.0007 \\
\hline & 0 & 1 & $08 / 04 / 80$ & PU-238 & 0.00979 & 0.0021 & & & 0 & 1 & $03 / 13 / 91$ & PU-238 & 0.0004 \\
\hline & 0 & 1 & $08 / 10 / 81$ & PU-238 & 0.0046 & 0.00091 & & & 0 & 1 & $06 / 03 / 93$ & PU-238 & 0.0005 \\
\hline & 0 & 1 & $08 / 30 / 82$ & PU-238 & 0.00819 & 0.00181 & & & 0 & 1 & $08 / 15 / 94$ & PU-238 & 0.0006 \\
\hline & 0 & 1 & $08 / 12 / 83$ & PU-238 & 0.00913 & 0.00286 & & & 0 & 1 & $06 / 14 / 77$ & PU-239,240 & 0.0245 \\
\hline & 0 & 1 & $05 / 15 / 84$ & PU-238 & 0.0014 & 0.000572 & 0.000587 & & 0 & 1 & $08 / 10 / 78$ & PU-239,240 & 0.0135 \\
\hline & 0 & 1 & $05 / 31 / 85$ & PU-238 & 0.00574 & 0.000914 & 0.00107 & & 0 & 1 & $09 / 11 / 79$ & PU.239,240 & 0.0563 \\
\hline & 0 & 1 & $05 / 01 / 86$ & PU-238 & 0.00527 & 0.000757 & 0.000924 & & 0 & 1 & $08 / 05 / 80$ & PU-239,240 & 0.0261 \\
\hline & 0 & 1 & $05 / 07 / 87$ & PU-238 & 0.00211 & 0.000486 & 0.000536 & & 0 & 1 & 08/10/81 & PU-239,240 & 0.0236 \\
\hline & 0 & 1 & $03 / 31 / 88$ & PU-238 & 0.00926 & 0.000999 & 0.00137 & & 0 & 1 & $08 / 10 / 81$ & PU-239,240 & 0.0421 \\
\hline & 0 & 1 & $04 / 05 / 88$ & PU-238 & 0.0106 & 0.000961 & 0.00142 & & 0 & 1 & $08 / 30 / 82$ & PU-239,240 & 0.0588 \\
\hline & 0 & 1 & $05 / 03 / 89$ & PU-238 & 0.00541 & 0.00103 & 0.0012 & & 0 & 1 & $08 / 12 / 83$ & PU-239,240 & 0.0511 \\
\hline & 0 & 1 & $10 / 04 / 90$ & PU-238 & 0.0396 & 0.00308 & 0.00566 & & 0 & 1 & $05 / 17 / 84$ & PU-239,240 & 0.0326 \\
\hline & 0 & 1 & $08 / 13 / 91$ & PU-238 & 0.00307 & 0.000568 & 0.000647 & & 0 & 1 & $05 / 31 / 85$ & PU-239,240 & 0.0297 \\
\hline & 0 & 1 & $06 / 03 / 93$ & PU-238 & 0.00386 & 0.000633 & 0,000742 & & 0 & 1 & $04 / 30 / 86$ & PU-239,240 & 0.0146 \\
\hline & 0 & 1 & $08 / 24 / 94$ & PU-238 & 0.00329 & 0.00125 & 0.00152 & & 0 & 1 & $05 / 07 / 87$ & PU-239,240 & 0.0309 \\
\hline & o & 1 & $08 / 18 / 75$ & PU-239,240 & 0.306 & 0 & & & 0 & 1 & $03 / 22 / 88$ & PU-239,240 & 0.0656 \\
\hline & 0 & 1 & $08 / 11 / 76$ & $P U-239.240$ & 0.0757 & 0 & & & 0 & 1 & $05 / 02 / 89$ & $P U-239240$ & 0.0314 \\
\hline
\end{tabular}


Table B.1. (contd)

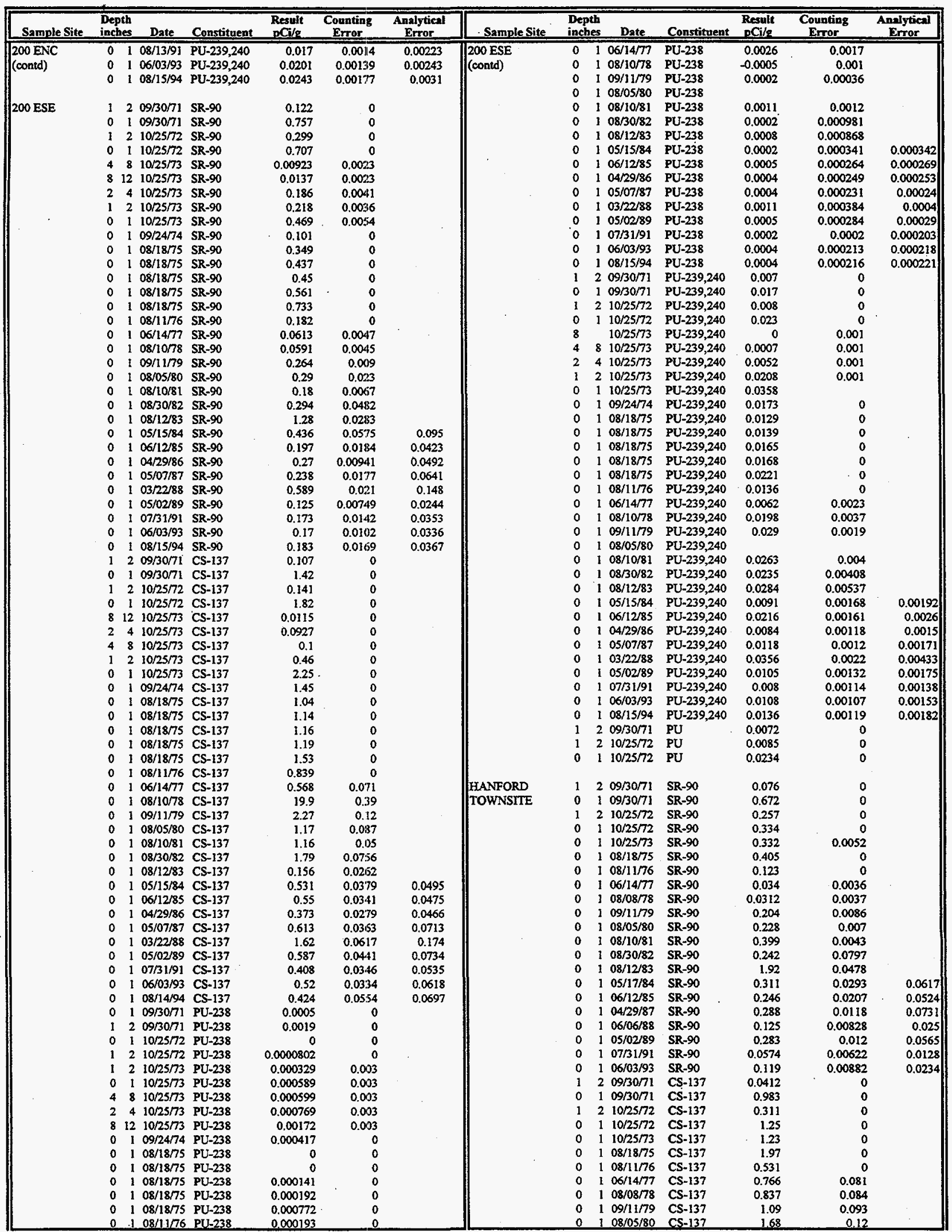


Table B.1. (contd)

\begin{tabular}{|c|c|c|c|c|c|c|c|c|c|c|c|c|c|}
\hline Sample Site & $\begin{array}{l}\text { Dep } \\
\text { ineh }\end{array}$ & & Date & Constiment & $\begin{array}{l}\text { Result } \\
\mathrm{pC} / 2\end{array}$ & $\begin{array}{c}\text { Counting } \\
\text { Error }\end{array}$ & $\begin{array}{c}\text { Analytical } \\
\text { Error }\end{array}$ & Sample Site & $\begin{array}{l}\text { Dep } \\
\text { inch }\end{array}$ & Date & Constitnent & $\begin{array}{l}\text { Restult } \\
\text { pCis } / 2\end{array}$ & $\begin{array}{l}\text { Counting } \\
\text { Error }\end{array}$ \\
\hline HANFORD & 0 & 1 & $08 / 10 / 81$ & CS-137 & 1.57 & 0.06 & & SE FFTF & 0 & $104 / 29 / 86$ & CS- 137 & 0.0444 & 0.0169 \\
\hline TOWNSITE & 0 & 1 & $08 / 30 / 82$ & CS-137 & 0.961 & 0.0803 & & (contd) & 0 & $106 / 09 / 88$ & CS-137 & 0.118 & 0.0242 \\
\hline (contd) & 0 & 1 & $08 / 12 / 83$ & CS-137 & 1.02 & 0.0711 & & & 0 & $105 / 03 / 89$ & CS-137 & 0.217 & 0.0278 \\
\hline & 0 & 1 & $05 / 17 / 84$ & CS-137 & 0.913 & 0.0533 & 0.0764 & & 0 & $110 / 08 / 90$ & CS-137 & & \\
\hline & 0 & 1 & $06 / 12 / 85$ & CS-137 & 1.1 & 0.0544 & 0.0855 & & 0 & $108 / 13 / 91$ & CS-137. & 0.142 & 0.024 \\
\hline & 0 & 1 & $04 / 29 / 87$ & CS-137 & 1.14 & 0.0574 & 0.128 & & 0 & 1. $06 / 03 / 93$ & $\mathrm{CS}-137$ & 0.185 & 0.0272 \\
\hline & 0 & 1 & $06 / 06 / 88$ & CS-137 & 0.882 & 0.0554 & 0.104 & & 0 & $108 / 15 / 94$ & CS-137 & 0.0031 & 0.0286 \\
\hline & 0 & 1 & $05 / 02 / 89$ & CS-137 & 1.17 & 0.0525 & 0.128 & & 0 & $108 / 20 / 75$ & PU-238 & 8E-05 & 0 \\
\hline - & 0 & 1 & $07 / 31 / 91$ & CS-137 & 0.271 & 0.028 & 0.039 & & 0 & $106 / 14 / 77$ & PU-238 & 0.0084 & 0.0026 \\
\hline & 0 & 1 & $06 / 03 / 93$ & CS-137 & 0.675 & 0.0419 & 0.0795 & & 0 & $108 / 08 / 78$ & PU-238 & 0.0047 & 0.0024 \\
\hline & 1 & 2 & $09 / 30 / 71$ & PU-238 & 0.003 & 0 & & & 0 & $109 / 11 / 79$ & PU-238 & 0.0002 & 0.00096 \\
\hline & 0 & 1 & $09 / 30 / 71$ & PU-238 & 0.0049 & 0 & & & 0 & $108 / 05 / 80$ & PU-238 & 0.0023 & 0.0012 \\
\hline & 1 & 2 & $10 / 25 / 72$ & PU-238 & 0 & 0 & & & 0 & $108 / 10 / 81$ & PU-238 & 0.0011 & 0.00067 \\
\hline & 0 & 1 & $10 / 25 / 72$ & PU-238 & 0.00492 & 0 & & & 0 & $108 / 30 / 82$ & PU-238 & -0.0007 & 0.000492 \\
\hline & 0 & 1 & $10 / 25 / 73$ & PU-238 & 0.00252 & 0.003 & & & 0 & $108 / 12 / 83$ & PU-238 & 0 & 0 \\
\hline & 0 & 1 & $08 / 18 / 75$ & PU-238 & 0.000472 & 0 & & & 0 & $105 / 17 / 84$ & PU-238 & 0.0003 & 0.000195 \\
\hline . & 0 & 1 & $08 / 11 / 76$ & PU-238 & $-1.31 \mathrm{E}-05$ & 0 & & & 0 & $106 / 05 / 85$ & PU-238 & 2E-05 & $9.23 \mathrm{E}-05$ \\
\hline & 0 & 1 & $06 / 14 / 77$ & PU-238 & 0.000987 & 0.00099 & & & 0 & I $04 / 29 / 86$ & PU-238 & 0.0002 & 0.000156 \\
\hline & 0 & 1 & $08 / 08 / 78$ & PU-238 & $-5.24 \mathrm{E}-05$ & 0.0014 & & & 0 & I $06 / 09 / 88$ & PU-238 & 0.0002 & 0.000163 \\
\hline & 0 & 1 & $09 / 11 / 79$ & PU-238 & 0.00346 & 0.0032 & & & 0 & $105 / 03 / 89$ & PU-238 & 0.0002 & 0.000213 \\
\hline & 0 & 1 & $08 / 05 / 80$ & PU-238 & 0.0056 & 0.0012 & & & 0 & $110 / 08 / 90$ & PU-238 & & \\
\hline & 0 & 1 & $08 / 10 / 81$ & PU-238 & -0.000304 & 0.0003 & & & 0 & $108 / 13 / 91$ & PU-238 & 0.0001 & 0.000153 \\
\hline & 0 & 1 & $08 / 30 / 82$ & PU-238 & 0.0000716 & 0.000738 & & & 0 & $106 / 03 / 93$ & PU-238 & 0.0001 & 0.000157 \\
\hline & 0 & 1 & $08 / 12 / 83$ & PU-238 & 0 & 0 & & & 0 & $108 / 15 / 94$ & PU-238 & 0.0008 & 0.000717 \\
\hline & 0 & 1 & $05 / 17 / 84$ & PU-238 & 0 & 0 & 0.00035 & & 0 & $108 / 20 / 75$ & PU-239,240 & 0.0027 & 0 \\
\hline & 0. & 1 & $06 / 12 / 85$ & PU-238 & 0.000368 & 0.000231 & 0.000234 & & 0 & $106 / 14 / 77$ & PU-239,240 & 0.0086 & 0.0026 \\
\hline & 0 & 1 & $04 / 29 / 87$ & PU-238 & 0.000495 & 0.000374 & 0.000379 & & 0 & $108 / 08 / 78$ & PU-239,240 & 0.0054 & 0.0023 \\
\hline & 0 & 1 & $06 / 06 / 88$ & PU-238 & 0.000746 & 0.000316 & 0.000326 & & 0 & $109 / 11 / 79$ & PU-239,240 & 0.0243 & 0.0041 \\
\hline & 0 & I & $05 / 02 / 89$ & PU-238 & 0.000815 & 0.000495 & 0.000506 & & 0 & $108 / 05 / 80$ & PU-239,240 & 0.007 & 0.0017 \\
\hline o & 0 & 1 & $07 / 31 / 91$ & PU-238 & 0.000016 & 0.000096 & 0.0001 & . & 0 & I $08 / 10 / 91$ & PU-239,240 & 0.003 & 0.00082 \\
\hline & 0 & 1 & $06 / 03 / 93$ & PU-238 & 0.000715 & 0.000271 & 0.000281 & & 0 & $108 / 30 / 82$ & PU-239,240 & 0.0051 & 0.00194 \\
\hline & 1 & 2 & $09 / 30 / 71$ & PU-239,240 & 0 & 0 & & & 0 & $108 / 12 / 83$ & PU-239,240 & 0.0043 & 0.00179 \\
\hline & 0 & 1 & $09 / 30 / 71$ & PU-239,240 & 0.022 & 0 & & . & 0 & $105 / 17 / 84$ & PU-239,240 & 0.0087 & 0.00106 \\
\hline & 1 & 2 & $10 / 25 / 72$ & PU-239,240 & 0.004 & 0 & & & 0 & $106 / 05 / 85$ & PU-239,240 & 0.0021 & 0.000494 \\
\hline & 0 & 1 & $10 / 25 / 72$ & PU-239,240 & 0.024 & 0 & & & 0 & $104 / 29 / 86$ & PU-239,240 & 0.0007 & 0.000283 \\
\hline & 0 & 1 & $10 / 25 / 73$ & PU: 239,240 & 0.015 & 0 & & & 0 & $106 / 09 / 88$ & PU-239,240 & 0.0032 & 0.000607 \\
\hline & 0 & 1 & $08 / 18 / 75$ & PU-239,240 & 0.0196 & 0 & & & 0 & $105 / 03 / 89$ & PU-239,240 & 0.0064 & 0.00106 \\
\hline & 0 & 1 & $08 / 11 / 76$ & PU-239,240 & 0.0109 & 0 & & & 0 & $1 \quad 10 / 08 / 90$ & PU-239,240 & & \\
\hline & 0 & 1 & $06 / 14 / 77$ & PU-239,240 & 0.0188 & 0.0029 & & & 0 & $108 / 13 / 91$ & PU-239,240 & 0.004 & 0.000731 \\
\hline & 0 & 1 & $08 / 08 / 78$ & PU-239,240 & -0.000172 & 0.0011 & & & 0 & I $06 / 03 / 93$ & PU-239,240 & 0.0032 & 0.000672 \\
\hline & 0 & I & $09 / 11 / 79$ & PU-239,240 & 0.0198 & 0.0067 & & & 0 & $108 / 15 / 94$ & PU-239,240 & 0.0008 & 0.000716 \\
\hline & 0 & 1 & $08 / 05 / 80$ & PU-239,240 & 0.0419 & 0.0029 & & & & & & & \\
\hline & 0 & 1 & $08 / 10 / 81$ & PU-239,240 & 0.0231 & 0.0016 & & NE FFTF & 0 & $108 / 20 / 75$ & SR-90 & 0.0594 & 0 \\
\hline & 0 & 1 & $08 / 30 / 82$ & PU-239,240 & 0.0153 & 0.00277 & & & 0 & $108 / 10 / 76$ & SR-90 & 0.316 & 0 \\
\hline & 0 & 1 & $08 / 12 / 83$ & PU-239,240 & 0.0211 & 0.00366 & & & 0 & $106 / 14 / 77$ & SR-90 & 0.0185 & 0.0036 \\
\hline & 0 & 1 & $05 / 17 / 84$ & PU-239,240 & 0.0156 & 0.0027 & 0.00347 & & 0 & $108 / 08 / 78$ & SR-90 & 0.0426 & 0.0046 \\
\hline . & 0 & 1 & $06 / 12 / 85$ & PU-239,240 & 0.00585 & 0.00088 & 0.00105 & & 0 & $109 / 11 / 79$ & SR-90 & 0.0853 & 0.0067 \\
\hline & 0 & 1 & $04 / 29 / 87$ & PU-239,240 & 0.0192 & 0.00233 & 0.00335 & & 0 & $108 / 05 / 80$ & SR-90 & 0.0416 & 0.011 \\
\hline & 0 & 1 & $06 / 06 / 88$ & PU-239,240 & 0.0209 & 0.0016 & 0.00269 & & 0 & $108 / 10 / 81$ & SR-90 & 0.0378 & 0.0074 \\
\hline & 0 & 1 & $05 / 02 / 89$ & PU-239,240 & 0.027 & 0.00263 & 0.00422 & & 0 & $108 / 30 / 82$ & SR-90 & 0.0415 & 0.035 \\
\hline & 0 & 1 & $07 / 31 / 91$ & PU-239,240 & 0.00368 & 0.000846 & 0.000925 & & 0 & $108 / 12 / 83$ & SR-90 & 0.519 & 0,0204 \\
\hline & 0 & 1 & $06 / 03 / 93$ & PU-239,240 & 0.0148 & 0.00118 & 0.00188 & . & 0 & $105 / 17 / 84$ & SR-90 & 0.178 & 0.0208 \\
\hline & 1 & 2 & $09 / 30 / 71$ & PU & 0 & 0 & & & 0 & $106 / 05 / 85$ & SR-90 & 0.172 & 0.0179 \\
\hline & 0 & 1 & $09 / 30 / 71$ & PU & 0.0224 & 0 & & & 0 & $104 / 29 / 87$ & SR-90 & 0.0855 & 0.0085 \\
\hline & 1 & 2 & $10 / 25 / 72$ & PU & 0.00448 & 0 & & & 0 & $106 / 09 / 88$ & SR-90 & 0.0919 & 0.00618 \\
\hline & 0 & I & $10 / 25 / 72$ & PU & 0.0235 & 0 & & & 0 & $105 / 03 / 89$ & SR-90 & 0.0499 & 0.0054 \\
\hline & & & & & & & & & 0 & $108 / 13 / 91$ & SR-90 & 0.0959 & 0.00718 \\
\hline SE FFTF & 0 & 1 & $08 / 20 / 75$ & SR-90 & 0.173 & 0 & & & 0 & $106 / 03 / 93$ & SR-90. & 0.04 & 0.00564 \\
\hline & 0 & 1 & $06 / 14 / 77$ & SR-90 & 0.131 & 0.0077 & & & 0 & $108 / 15 / 94$ & SR-90 & 0.0401 & 0.00895 \\
\hline & 0 & 1 & $08 / 08 / 78$ & SR-90 & 0.00875 & 0.0033 & & & 0 & $108 / 20 / 75$ & CS-137 & 0.0196 & 0 \\
\hline & 0 & 1 & $09 / 11 / 79$ & SR-90 & 0.0765 & 0.0067 & & & 0 & $108 / 10 / 76$ & CS-137 & 0.627 & 0 \\
\hline & 0 & 1 & $08 / 05 / 80$ & SR-90 & 0.0879 & 0.0067 & & & 0 & $106 / 14 / 77$ & CS-137 & 1.68 & 0.12 \\
\hline & 0 & 1 & $08 / 10 / 81$ & SR-90 & 0.0493 & 0.0023 & & & 0 & $108 / 08 / 78$ & CS-137 & 0.137 & 0.037 \\
\hline & 0 & 1 & $08 / 30 / 82$ & SR-90 & 0.047 & 0.045 & & & 0 & $109 / 11 / 79$ & CS-137 & 0.188 & 0.039 \\
\hline & 0 & 1 & $08 / 12 / 83$ & SR-90 & 0.541 & 0.0188 & & & 0 & $108 / 05 / 80$. & CS-137 & 0.217 & 0.041 \\
\hline & 0 & 1 & $05 / 17 / 84$ & SR-90 & 0.032 & 0.0536 & 0.00772 & & 0 & $108 / 10 / 81$ & CS-137 & 0.105 & 0.018 \\
\hline & 0 & 1 & $06 / 05 / 85$ & SR-90 & 0.196 & 0.0165 & 0.0423 & & 0 & $108 / 30 / 82$ & CS-137 & 0.126 & 0.023 \\
\hline & 0 & 1 & $04 / 29 / 86$ & SR-90 & 0.0438 & 0.00486 & 0.01 & & 0 & $108 / 12 / 83$ & CS-137 & 0.177 & 0.0273 \\
\hline & 0 & 1 & $06 / 09 / 88$ & SR-90 & 0.07 & 0.00601 & 0.0149 & & 0 & $105 / 17 / 84$ & CS-137 & 0.117 & 0.0243 \\
\hline & 0 & 1 & $05 / 03 / 89$ & SR-90 & 0.0623 & 0.0059 & 0.0136 & & 0 & $106 / 05 / 85$ & CS-137 & 0.0803 & 0.0272 \\
\hline & 0 & 1 & $10 / 08 / 90$ & SR-90 & & & & & 0 & $104 / 29 / 87$ & CS-137 & 0.325 & 0.0326 \\
\hline & 0 & 1 & $08 / 31 / 91$ & SR-90 & 0.0506 & 0.00765 & 0.0123 & & 0 & $106 / 09 / 88$ & CS-137 & 0.239 & 0.0276 \\
\hline & 0 & 1 & $06 / 03 / 93$ & SR-90 & 0.0492 & 0.0066 & 0.0113 & & 0 & $105 / 03 / 89$ & CS-137 & 0.186 & 0.0218 \\
\hline & 0 & 1 & $08 / 15 / 94$ & SR-90 & 0.0275 & 0.00604 & 0.00788 & & 0 & $108 / 13 / 91$ & CS- 137 & 0.387 & 0.0375 \\
\hline & 0 & 1 & $08 / 20 / 75$ & CS-137 & 0.177 & 0 & & & 0 & $106 / 03 / 93$ & CS-137 & 0.0845 & 0.0192 \\
\hline & 0 & 1 & $06 / 14 / 77$ & CS-137 & 0.519 & 0.068 & & . & 0 & $108 / 15 / 94$ & CS-137 & 0.0779 & 0.0475 \\
\hline & 0 & 1 & $08 / 08 / 78$ & CS- 137 & 0.378 & 0.058 & & & 0 & $108 / 20 / 75$ & PU-238 & 0 & 0 \\
\hline & 0 & 1 & $09 / 11 / 79$ & CS-137 & 0.19 & 0.043 & & & 0 & $108 / 10 / 76$ & PU-238 & 0.0011 & 0 \\
\hline & 0 & 1 & $08 / 05 / 80$ & CS- 137 & 0.402 & 0.053 & & & 0 & $106 / 14 / 77$ & PU-238 & .0 .0006 & 0.067 \\
\hline & 0 & 1 & $08 / 10 / 81$ & CS-137 & 0.0784 & 0.017 & & & 0 & $108 / 08 / 78$ & PU-238 & 0.0001 & 0.0034 \\
\hline & 0 & 1 & $08 / 30 / 82$ & CS-137 & 0.194 & 0.03 & & & 0 & $109 / 11 / 79$ & PU-238 & -0.0004 & 0.0012 \\
\hline & 0 & 1 & $08 / 12 / 83$ & CS-137 & 0.198 & 0.0309 & & & 0 & $108 / 05 / 80$ & PU-238 & 0.0003 & 0.00087 \\
\hline & 0 & 1 & $05 / 17 / 84$ & CS-137 & 0.0801 & 0.0194 & 0.02 & & 0 & $108 / 10 / 81$ & PU-238 & -0.001 & 0.00028 \\
\hline & 0 & 1 & $06 / 05 / 85$ & $C S-137$ & 0.083 & 0.0212 & 0.0218 & & 0 & $108 / 30 / 82$ & PU-238 & $-0,0004$ & 0.000751 \\
\hline
\end{tabular}


Table B.1. (contd)

\begin{tabular}{|c|c|c|c|c|c|c|c|c|c|c|c|c|c|}
\hline Sample Site & $\begin{array}{l}\text { Dep } \\
\text { inch }\end{array}$ & & Date & Coastituent & $\begin{array}{l}\text { Result } \\
\text { pCils. }\end{array}$ & $\begin{array}{l}\text { Counting; } \\
\text { Error }\end{array}$ & $\begin{array}{c}\text { Analytical } \\
\text { Error }\end{array}$ & Sample Site & $\begin{array}{l}\text { Dep } \\
\text { inch }\end{array}$ & Date & Constituent & $\begin{array}{l}\text { Resuit } \\
\text { pCiga }\end{array}$ & $\begin{array}{c}\text { Counting } \\
\text { Error }\end{array}$ \\
\hline NE FFTF & 0 & 1 & $08 / 12 / 83$ & PU-238 & 0 & 0 & & WYE & 0 & $108 / 16 / 82$ & CS-137 & 1.06 & 0.0566 \\
\hline (contd) & 0 & 1 & $05 / 17 / 84$ & PU-238 & 0.00125 & 0.000501 & 0.000518 & BARRICADE & 0 & $108 / 11 / 83$ & CS-137 & 0.842 & 0.0543 \\
\hline & 0 & 1 & $06 / 05 / 85$ & PU-238 & 0.0000405 & $7.44 \mathrm{E}-05$ & 7.45E-05 & (contd) & 0 & $105 / 15 / 84$ & CS-137 & 0.68 & 0.0398 \\
\hline & 0 & 1 & $04 / 29 / 87$ & PU-238 & 0.00026 & 0.000165 & 0.000167 & & 0 & $107 / 03 / 85$ & CS-137 & 1.32 & 0.0578 \\
\hline & 0 & 1 & $06 / 09 / 88$ & PU-238 & 0.000171 & 0.000142 & 0.000144 & & 0 & $104 / 29 / 83$ & CS-137 & 0.588 & 0.0359 \\
\hline & 0 & 1 & $05 / 03 / 89$ & PU-238 & 0.000516 & 0.000376 & 0.000382 & & 0 & $105 / 25 / 88$ & CS-137 & 0.559 & 0.0397 \\
\hline & 0 & 1 & $08 / 13 / 91$ & PU-238 & 0.000392 & 0.000258 & 0.000263 & & 0 & $105 / 03 / 89$ & CS-137 & 0.391 & 0.0399 \\
\hline & 0 & 1 & $06 / 03 / 93$ & PU-238 & 0.0000645 & 0.000142 & 0.000143 & & 0 & $107 / 31 / 91$ & CS-137 & 0.66 & 0.0403 \\
\hline & 0 & 1 & $08 / 15 / 94$ & PU-238 & 0.0000854 & 0.000124 & 0.000126 & & 0 & $106 / 03 / 93$ & CS-137 & 0.354 & 0.0299 \\
\hline & 0 & 1 & $08 / 20 / 75$ & PU-239,240 & 0.000925 & 0 & & & 1 & $209 / 30 / 71$ & PU-238 & 0 & 0 \\
\hline & 0 & 1 & $08 / 10 / 76$ & PU-239,240 & 0.0134 & 0 & & & 0 & 1 $09 / 30 / 71$ & PU-238 & 0.0002 & 0 \\
\hline & 0 & 1 & $06 / 14 / 77$ & PU-239,240 & 0.165 & 0.12 & & & 0 & $110 / 25 / 72$ & PU-238 & 0.0034 & 0 \\
\hline & 0 & 1 & $08 / 08 / 78$ & PU-239,240 & 0.0017 & 0.0036 & & & 1 & $210 / 25 / 72$ & PU-238 & 0.0048 & 0 \\
\hline & 0 & 1 & $09 / 11 / 79$ & PU-239,240 & .0 .00241 & 0.0023 & & & 0 & $110 / 25 / 73$ & PU-238 & 0.0017 & 0.003 \\
\hline & 0 & 1 & $08 / 05 / 80$ & PU-239,240 & 0.00388 & 0.0016 & & & 0 & $106 / 14 / 77$ & PU-238 & 0.0056 & 0.0041 \\
\hline & 0 & 1 & $08 / 10 / 81$ & PU-239,240 & 0.00261 & 0.00079 & & & 0 & $108 / 08 / 78$ & PU-238 & 0.0017 & 0.0015 \\
\hline & 0 & 1 & 08/3-/82 & PU-239,240 & 0.00241 & 0.0013 & & & 0 & $109 / 11 / 79$ & PU.238 & 0.0002 & 0.00084 \\
\hline & 0 & 1 & $08 / 12 / 83$ & PU-239,240 & 0.00287 & 0.0006677 & & & 0 & $108 / 05 / 80$ & PU-238 & 0.0009 & 0.00087 \\
\hline & 0 & 1 . & $05 / 17 / 84$ & PU-239,240 & 0.0021 & 0.000669 & 0.000706 & & 0 & $108 / 10 / 81$ & PU-238 & -0.0004 & 0.00035 \\
\hline & 0 & 1 & $06 / 05 / 85$ & PU-239,240 & 0.0025 & 0.000503 & 0.000553 & & 0 & $108 / 16 / 82$ & PU-238 & 0.0006 & 0.000796 \\
\hline & 0 & 1 & $04 / 29 / 87$ & PU-239,240 & 0.00554 & 0.00076 & 0.000942 & & 0 & $108 / 11 / 83$ & PU-238 & 0.0005 & 0.000372 \\
\hline & 0 & 1 & $06 / 09 / 88$ & PU-239,240 & 0.00492 & 0.000727 & 0.000882 & & 0 & $105 / 15 / 84$ & PU-238 & 0.001 & 0.000829 \\
\hline & 0 & 1 & $05 / 03 / 89$ & PU-239,240 & 0.00383 & 0.00105 & 0.00115 & & 0 & $107 / 03 / 85$ & PU-238 & 0.0006 & 0.000282 \\
\hline & 0 & 1 & $08 / 13 / 91$ & PU-239,240 & 0.0085 & 0.00118 & 0.0015 & & 0 & $104 / 29 / 87$ & PU-238 & 0.0006 & 0.000253 \\
\hline & 0 & 1 & $06 / 03 / 93$ & PU-239,240 & 0.00271 & $0.00054 / 7$ & 0.000613 & & 0 & $105 / 25 / 88$ & PU.238 & 0.0004 & 0.000207 \\
\hline & 0 & 1 & $08 / 15 / 94$ & PU-239,240 & 0.0019 & 0.0004418 & 0.000488 & & 0 & $105 / 03 / 89$ & PU-238 & 0.0002 & 0.000235 \\
\hline & & & & & & & & & 0 & $107 / 31 / 91$ & PU-238 & 0.0005 & 0.000475 \\
\hline FFTF CP 62 & 1 & 2 & $09 / 30 / 71$ & SR-90 & 0.091 & 0 & & & 0 & $106 / 03 / 93$ & PU-238 & 0.0003 & 0.000177 \\
\hline & 0 & 1 & $09 / 30 / 71$ & SR-90 & 0.091 & 0 & & & $t$ & $209 / 30 / 71$ & PU-239,240 & 0.009 & 0 \\
\hline & 1 & 2 & $10 / 25 / 72$ & SR-90 & 0.0192 & 0 & & & 0 & $109 / 30 / 71$ & PU-239,240 & 0.014 & 0 \\
\hline & 0 & 1 & $10 / 25 / 72$ & SR-90 & 0.0453 & 0 & & & 0 & $110 / 25 / 72$ & PU-239,240 & 0.014 & 0 \\
\hline & 0 & 1 & $10 / 25 / 73$ & SR-90 & 0.0757 & 0.0027 & & & 1 & $210 / 25 / 72$ & PU-239,240 & 0.016 & 0 \\
\hline & 0 & 1 & $09 / 24 / 74$ & SR-90 & 0.0178 & 0 & & & 0 & $110 / 25 / 73$ & PU. 239,240 & 0.0116 & 0 \\
\hline & 1 & 2 & $09 / 30 / 71$ & CS-137 & 0.0235 & 0 & & & 0 & $106 / 14 / 77$ & PU-239,240 & 0.0095 & 0.0049 \\
\hline & 0 & 1 & $09 / 30 / 71$ & CS-137 & 0.194 & 0 & & & 0 & $108 / 08 / 78$ & PU-239,240 & 0.0063 & 0.0021 \\
\hline & 1 & 2 & $10 / 25 / 72$ & CS-137 & 0.052 & 0 & & & 0 & $109 / 11 / 79$ & PU-239,240 & 0.0178 & 0.0029 \\
\hline & 0 & 1 & $10 / 25 / 72$ & CS- 137 & 0.131 & 0 & & & 0 & $108 / 05 / 80$ & PU-239,240 & 0.013 & 0.0023 \\
\hline & 0 & 1 & $10 / 25 / 73$ & CS-137 & 0.264 & 0 & & & 0 & $108 / 10 / 81$ & PU-239,240 & 0.0116 & 0.0013 \\
\hline & 0 & 1 & $09 / 24 / 74$ & CS-137 & 0.136 & 0 & & & 0 & $108 / 16 / 82$ & PU-239,240 & 0.018 & 0.0027 \\
\hline & 1 & 2 & $09 / 30 / 71$ & PU-238 & 0 & 0 & & & 0 & $108 / 11 / 83$ & PU-239,240 & 0.0167 & 0.00216 \\
\hline & 0 & 了 & $09 / 30 / 71$ & PU-238 & 0.00187 & 0 & & & 0 & $105 / 15 / 84$ & PU-239,240 & 0.0138 & 0.00233 \\
\hline & 0 & 1 & $10 / 25 / 72$ & PU-238 & 0.0037 & 0 & & & 0 & $107 / 03 / 85$ & PU-239,240 & 0.0173 & 0.00149 \\
\hline & 1 & 2 & $10 / 25 / 72$ & PU-238 & 0.00605 & 0 & & & 0 & $104 / 29 / 8 ?$ & PU-239,240 & 0.0107 & 0.00103 \\
\hline & 0 & 1 & $10 / 25 / 73$ & PU-238 & 0.00104 & 0.003 & & & 0 & ] $05 / 25 / 88$ & PU-239,240 & 0.0083 & 0.000856 \\
\hline & 0 & 1 & $09 / 24 / 74$ & PU-238 & 0.0000334 & 0 & & & 0 & $105 / 03 / 89$ & PU-239,240 & 0.0075 & 0.00133 \\
\hline & 1 & 2 & $09 / 30 / 71$ & PU-239,240 & 0 & 0 & & & 0 & $107 / 31 / 91$ & PU-239,240 & 0.0168 & 0.00255 \\
\hline & 0 & 1 & $09 / 30 / 71$ & PU-239,240 & 0.004 & 0 & & & 0 & $106 / 03 / 93$ & PU-239,240 & 0.0083 & 0.00092 \\
\hline & 0 & 1 & $10 / 25 / 72$ & PU-239,240 & 0.005 & 0 & & & 1 & $209 / 30 / 71$ & PU & 0.0093 & 0 \\
\hline & 1 & 2 & $10 / 25 / 72$ & PU-239,240 & 0.011 & 0 & & & 0 & $109 / 30 / 71$ & PU & 0.0136 & 0 \\
\hline & 0 & 1 & $10 / 25 / 73$ & PU-239,240 & 0.00349 & 0.001 & & & 0 & $110 / 25 / 72$ & PU & 0.0141 & 0 \\
\hline & 0 & 1 & $09 / 24 / 74$ & PU-239,240 & 0.00282 & 0 & & & 1 & $210 / 25 / 72$ & PU & 0.0162 & 0 \\
\hline & 1 & 2 & $09 / 30 / 71$ & PU & 0 & 0 & & & & & & & \\
\hline & 0 & 1 & $09 / 30 / 71$ & PU & 0.00409 & 0 & & WYE & 0 & $18 / 16 / 82$ & SR-90 & 0.24 & 0.0511 \\
\hline & 0 & 1 & $10 / 25 / 72$ & PU & 0.00481 & 0 & & BARRICADE & 0 & $18 / 11 / 83$ & SR-90 & 0.919 & 0.0252 \\
\hline & 1 & 2 & $10 / 25 / 72$ & PU & 0.0108 & 0 & & (QC_SAMP) & 0 & $16 / 6 / 84$ & SR-90 & 0.158 & 0.0119 \\
\hline & & & & & & & & & 0 & $17 / 3 / 85$ & SR-90 & 0.261 & 0.0219 \\
\hline WYE & 0 & 1 & $09 / 30 / 71$ & SR-90 & 0.217 & 0 & & & 0 & $14 / 29 / 86$ & SR-90 & 0.0451 & 0.00453 \\
\hline BARRICADE & 1 & 2 & $10 / 25 / 72$ & SR-90 & 0.175 & 0 & & & 0 & $14 / 29 / 87$ & SR-90 & 0.125 & 0.00826 \\
\hline & 0 & 1 & $10 / 25 / 72$ & SR-90 & 0.285 & 0 & & & 0 & $15 / 25 / 88$ & SR-90 & 0.0112 & 0.00338 \\
\hline & 0 & 1 & $10 / 25 / 73$ & SR-90 & 0.134 & 0.0036 & & & 0 & $15 / 3 / 89$ & SR-90 & 0.104 & 0.00681 \\
\hline & 0 & $\mathfrak{l}$ & $06 / 14 / 77$ & SR-90 & 0.14 & 0.0081 & & & 0 & $18 / 13 / 91$ & SR-90 & 0.11 & 0.00673 \\
\hline & 0 & 1 & $08 / 08 / 78$ & SR-90 & 0.0369 & 0.0037 & & & 0 & $16 / 3 / 93$ & SR-90 & 0.125 & 0.00898 \\
\hline & 0 & 1 & $09 / 11 / 79$ & SR-90 & 0.26 & 0.0087 & & . & 0 & $18 / 23 / 94$ & SR-90 & 0.0823 & 0.0079 \\
\hline & 0 . & 1 & $08 / 05 / 80$ & SR-90 & 0.232 & 0.0068 & & & 0 & $18 / 16 / 82$ & CS-137 & 1.16 & 0.083 \\
\hline & 0 & 1 & $08 / 10 / 81$ & SR-90 & 0.198 & 0.023 & & & 0 & $18 / 11 / 83$ & CS-137 & 0.772 & 0.0523 \\
\hline & 0 & 1 & $08 / 16 / 82$ & SR-90 & 0.21 & 0.0265 & & & 0 & $16 / 6 / 84$ & CS-137 & 0.232 & 0.0256 \\
\hline & 0 & 1 & $08 / 11 / 83$ & SR-90 & 0.81 & 0.0258 & & & 0 & $17 / 3 / 85$ & CS-137 & 0.854 & 0.0461 \\
\hline & 0 & 1 & $05 / 15 / 84$ & SR-90 & 0.305 & 0.0442 & 0.0694 & & 0 & $14 / 29 / 86$ & CS-137 & 0.0521 & 0.0189 \\
\hline & 0 & 1 & $07 / 03 / 85$ & SR-90 & 0.307 & 0.0186 & 0.0623 & & 0 & $14 / 29 / 87$ & CS-137 & 0.349 & 0.0321 \\
\hline & 0 & 1 & $04 / 29 / 87$ & SR-90 & 0.183 & 0.00878 & 0.0464 & & 0 & I $5 / 25 / 88$ & CS-137 & 0.0221 & 0.0138 \\
\hline & 0 & 1 & $05 / 25 / 88$ & SR-90 & 0.138 & 0.00736 & 0.0271 & & 0 & $15 / 3 / 89$ & CS- 137 & 0.642 & 0.0382 \\
\hline & 0 & 1 & $05 / 03 / 89$ & SR-90 & 0.106 & 0.00734 & 0.0215 & & 0 & 1 $8 / 13 / 91$ & CS-137 & 0.273 & 0.031 \\
\hline & 0 & 1 & $07 / 31 / 91$ & SR-90 & 0.231 & 0.0158 & 0.0443 & & 0 & $16 / 3 / 93$ & CS-137 & 0.399 & 0.0244 \\
\hline & 0 & 1 & $06 / 03 / 93$ & SR-90 & 0.0967 & 0.00768 & 0.0198 & & 0 & $18 / 23 / 94$ & CS-137 & 0.195 & 0.048 \\
\hline & 1 & 2 & $09 / 30 / 71$ & CS-137 & 0.294 & 0 & & & 0 & $18 / 16 / 82$ & PU-238 & 0.0001 & 0.000676 \\
\hline & 0 & 1 & $09 / 30 / 71$ & CS- 137 & 0.525 & 0 & & & 0 & $18 / 11 / 83$ & PU-238 & 0.0004 & 0.000293 \\
\hline & 1 & 2 & $10 / 25 / 72$ & CS-137 & 0.436 & 0 & & & 0 & $16 / 6 / 84$ & PU-238 & 0 & 0 \\
\hline & 0 & 1 & $10 / 25 / 72$ & CS-137 & 0.761 & 0 & & & 0 & $17 / 3 / 85$ & PU-238 & 0.0003 & 0.000231 \\
\hline & 0 & 1 & $10 / 25 / 73$ & CS-137 & 0.708 & 0 & & & 0 & $14 / 29 / 86$ & PU-238 & 0.0002 & 0.000188 \\
\hline & 0 & 1 & $06 / 14 / 77$ & CS-137 & 0.601 & 0.072 & & & 0 & 1 $4 / 29 / 87$ & PU-238 & 0.0005 & 0.000258 \\
\hline & 0 & $i$ & $08 / 08 / 78$ & CS-137 & 0.596 & 0,071 & & & 0 & I $5 / 25 / 88$ & PU-238 & $-2 E-05$ & 0 \\
\hline & 0 & 1 & $09 / 11 / 79$ & CS-137 & 0.793 & 0.072 & & & 0 & ] $5 / 3 / 89$ & PU-238 & 0.0015 & 0.000563 \\
\hline & 0 & 1 & $08 / 05 / 80$ & CS-137 & 1.08 & 0.096 & & & 0 & $18 / 13 / 91$ & PU-238 & 0.0002 & 0.000166 \\
\hline & 0 & 1 & $08 / 10 / 81$ & CS-137 & 0.688 & 0.039 & & & 0 & $16 / 3 / 93$ & PU-238 & 0.0003 & 0.000187 \\
\hline
\end{tabular}


Table B.1. (contd)

\begin{tabular}{|c|c|c|c|c|c|c|c|c|c|c|c|c|c|}
\hline Sample Site & $\begin{array}{l}\text { Dept } \\
\text { inche }\end{array}$ & & Date & Constituent & $\begin{array}{l}\text { Result } \\
\mathrm{pCi} / \mathrm{s}\end{array}$ & $\begin{array}{c}\text { Counting } \\
\text { Error }\end{array}$ & $\begin{array}{l}\text { Analytical } \\
\text { Error }\end{array}$ & Sample Site & $\begin{array}{l}\text { Dep } \\
\text { inch }\end{array}$ & Date & Constituent & $\begin{array}{l}\text { Result } \\
\mathrm{pCi} / 2\end{array}$ & $\begin{array}{l}\text { Counting } \\
\text { Error }\end{array}$ \\
\hline WYE & 0 & $\bar{i}$ & $8 / 23 / 94$ & PU-238 & 0.0000527 & 0.000126 & 0.000127 & PROSSER & 0 & $104 / 29 / 86$ & CS-137 & 0.317 & 0.0324 \\
\hline BARRICADE & 0 & 1 & $8 / 16 / 82$ & PU-239,240 & 0.0196 & 0.00278 & & BARRICADE & 0 & $105 / 25 / 88$ & CS-137 & 0.332 & 0.0271 \\
\hline (QC_SAMP) & 0 & 1 & $8 / 11 / 83$ & PU-239,240 & 0.0105 & 0.00152 & & (contd) & 0 & $105 / 03 / 89$ & CS-137 & 0.861 & 0.0514 \\
\hline$\left(\cos t^{\prime} d\right)$ & 0 & 1 & $6 / 6 / 84$ & PU-239,240 & 0.00487 & 0.00325 & 0.0035 & & 0 & $106 / 07 / 93$ & CS-137 & 0.269 & 0.0235 \\
\hline & 0 & 1 & $7 / 3 / 85$ & PU-239,240 & 0.00793 & 0.00113 & 0.00139 & & 0 & $109 / 24 / 74$ & PU-238 & 0.0007 & 0 \\
\hline & 0 & 1 & $4 / 29 / 86$ & PU-239,240 & 0.00168 & 0.000602 & 0.000633 & & 0 & $108 / 19 / 75$ & PU.238 & 0.0009 & 0 \\
\hline & 0 & 1 & $4 / 29 / 87$ & PU-239,240 & 0.00635 & 0.000952 & 0.00117 & & 0 & $106 / 14 / 77$ & PU-238 & 0.0032 & 0.0039 \\
\hline & 0 & 1 & $5 / 25 / 88$ & PU-239,240 & 0.000556 & 0.000242 & 0.00025 & & 0 & $108 / 08 / 78$ & PU-238 & -0.0012 & 0.0024 \\
\hline & 0 & 1 & $5 / 3 / 89$ & PU-239,240 & 0.0131 & 0.00166 & 0.00223 & & 0 & $109 / 12 / 79$ & PU.238 & -0.0004 & 0.0006 \\
\hline & 0 & 1 & $8 / 13 / 91$ & PU-239,240 & 0.00612 & 0.000913 & 0.00113 & & 0 & $108 / 04 / 80$ & PU-238 & & \\
\hline & 0 & 1 & $6 / 3 / 93$ & PU-239,240 & 0.00979 & 0.000947 & 0.00135 & & 0 & $108 / 11 / 81$ & PU-238 & -0.0004 & 0.00048 \\
\hline & 0 & 1 & $8 / 23 / 94$ & PU-239,240 & 0.00425 & 0.000859 & 0.001 & & 0 & $108 / 16 / 82$ & PU-238 & 0.0013 & 0.00113 \\
\hline & & & & & & & & & 0 & $108 / 23 / 83$ & PU-238 & 0.0015 & 0.00119 \\
\hline WYE & 0 & 1 & $8 / 16 / 82$ & SR-90 & 0.242 & 0.0422 & & & 0 & $105 / 15 / 84$ & PU-238 & 0.0007 & 0.000777 \\
\hline BARRICADE & 0 & 1 & $8 / 11 / 83$ & SR-90 & 0.935 & 0.0287 & & & 0 & $106 / 06 / 85$ & PU-238 & 0.0004 & 0.000293 \\
\hline (QC_SAMP _ & 0 & 1 & $6 / 6 / 84$ & SR-90 & 0.143 & 0.00834 & 0.0289 & & 0 & $104 / 29 / 86$ & PU-238 & 0.0002 & 0.000174 \\
\hline DUP) & 0 & 1 & $7 / 3 / 85$ & SR-90 & 0.441 & 0.0247 & 0.0894 & & 0 & $105 / 25 / 88$ & PU-238 & 0.0001 & 0.000109 \\
\hline & 0 & 1 & $4 / 29 / 86$ & SR-90 & 0.0413 & 0.00432 & 0.00873 & & 0 & $105 / 03 / 89$ & PU-238 & 0.0033 & 0.000742 \\
\hline & 0 & 1 & $4 / 29 / 87$ & SR-90 & 0.158 & 0.00942 & 0.0404 & & 0 & $106 / 07 / 93$ & PÜ-238 & 0.0003 & 0.000179 \\
\hline & 0 & $\mathrm{t}$ & $5 / 25 / 88$ & SR-90 & 0.0709 & 0.00623 & 0.0152 & & 0 & $109 / 24 / 74$ & PU-239,240 & $0.010 \mathrm{~L}$ & 0 \\
\hline & 0 & 1 & $5 / 3 / 89$ & SR-90 & 0.165 & 0.00871 & 0.0344 & & 0 & $108 / 19 / 75$ & PU-239,240 & 0.0045 & 0 \\
\hline & 0 & 1 & $8 / 13 / 91$ & SR-90 & 0.142 & 0.00776 & 0.0275 & & 0 & $106 / 14 / 77$ & PU-239,240 & 0.0137 & 0.0061 \\
\hline & 0 & 1 & $6 / 3 / 93$ & SR-90 & 0.109 & 0.00787 & 0.0219 & & 0 & $108 / 08 / 78$ & PU-239,240 & 0.0114 & 0.0052 \\
\hline & 0 & I & $8 / 23 / 94$ & SR-90 & 0.0966 & 0.00942 & 0.0205 & & 0 & $109 / 12 / 79$ & PU-239,240 & 0.016 & 0.0031 \\
\hline & 0 & I & $8 / 16 / 82$ & CS-137 & 1.14 & 0.0925 & & & 0 & $108 / 04 / 80$ & PU-239,240 & & \\
\hline & 0 & 1 & $8 / 11 / 83$ & CS-137 & 0.885 & 0.0526 & & & 0 & $108 / 11 / 81$ & PU-239,240 & 0.0059 & 0.0012 \\
\hline & 0 & 1 & $6 / 6 / 84$ & CS-137 & 0.312 & 0.0344 & 0.0391 & & 0 & $108 / 16 / 82$ & PU-239,240 & 0.0329 & 0.00428 \\
\hline & 0 & 1 & $7 / 3 / 85$ & CS-137. & 0.985 & 0.0489 & 0.0767 & & 0 & $108 / 23 / 83$ & PU-239,240 & 0.0203 & 0.00443 \\
\hline & 0 & I & $4 / 29 / 86$ & CS-137 & 0.0326 & 0.0134 & 0.0138 & & 0 & 1 05/15/84 & PU-239,240 & 0.0039 & 0.00161 \\
\hline & 0 & I & $4 / 29 / 87$ & CS-137 & 0.536 & 0.0442 & 0.0695 & & 0 & $106 / 06 / 85$ & PU-239,240 & 0.0192 & 0.00188 \\
\hline & 0 & 1 & $5 / 25 / 88$ & CS-137 & 0.165 & 0.0256 & 0.0305 & & 0 & $104 / 29 / 86$ & PU-239,240 & 0.0078 & 0.000987 \\
\hline & 0 & 1 & $5 / 3 / 89$ & CS-137 & 0.775 & 0.0488 & 0.0915 & & 0 & $105 / 25 / 88$ & PU-239,240 & 0.0062 & 0.000778 \\
\hline & 0 & 1 & $8 / 13 / 91$ & CS-137 & 0.508 & 0.039 & 0.0641 & . & 0 & $105 / 03 / 89$ & PU-239,240 & 0.0181 & 0.0017 \\
\hline & 0 & 1 & $6 / 3 / 93$ & CS-137 & 0.417 & 0.032 & 0.0526 & & 0 & $106 / 07 / 93$ & PU-239,240 & 0.0071 & 0.000876 \\
\hline & 0 & 1 & $8 / 23 / 94$ & CS-137 & 0.219 & 0.049 & 0.0537 & & & & & & \\
\hline & 0 & 1 & $8 / 16 / 82$ & PU-238 & 0.000804 & 0.000771 & & ALE & 0 & $108 / 20 / 75$ & SR-90 & 0.469 & 0 \\
\hline & 0 & 1 & $8 / 11 / 83$ & PU-238 & 0.000654 & 0.000335 & & & 0 & $108 / 10 / 76$ & SR-90 & 0.0154 & 0 \\
\hline & 0 & 1 & $6 / 6 / 84$ & PU-238 & 0.000939 & 0.000664 & 0.000677 & & 0 & $106 / 14 / 77$ & SR-90 & 0.0757 & 0.0056 \\
\hline & 0 & 1 & $7 / 3 / 85$ & PU-238 & 0.001 & 0.000486 & 0.000499 & & 0 & $108 / 10 / 78$ & SR-90 & 0.0058 & 0.0033 \\
\hline & 0 & 1 & $4 / 29 / 86$ & PU-238 & 0.0000346 & 6.93E-05 & $6.94 \mathrm{E}-05$ & & 0 & $109 / 12 / 79$ & SR-90 & 0.37 & 0.01 \\
\hline & 0 & 1 & $4 / 29 / 87$ & PU-238 & 0 & 0 & $8.92 \mathrm{E}-05$ & & 0 & $108 / 05 / 80$ & SR-90 & 0 & 0.0068 \\
\hline & 0 & 1 & $5 / 25 / 88$ & PU-238 & 0.000143 & 0.00013 & 0.000132 & & 0 & $108 / 13 / 81$ & SR-90 & 0.272 & 0.034 \\
\hline & 0 & 1 & $5 / 3 / 89$ & PU-238 & 0.000671 & 0.000543 & 0.000551 & & 0 & $108 / 16 / 82$ & SR-90 & 0.3 & 0.0584 \\
\hline & 0 & 1 & $8 / 13 / 91$ & PU-238 & 0.00034 & 0.000205 & 0.000209 & & 0 & $108 / 23 / 83$ & SR-90 & 1.63 & 0.0323 \\
\hline & 0 & I & 6/3/93 & PU-238 & 0.000259 & 0.000166 & 0.000169 & & 0 & $105 / 24 / 84$ & SR-90 & 0.358 & 0.0394 \\
\hline & 0 & 1 & $8 / 23 / 94$ & PU-238 & 0.000224 & 0.000182 & 0.000184 & & 0 & $106 / 12 / 85$ & SR-90 & 0.607 & 0.0349 \\
\hline & 0 & 1 & $8 / 16 / 82$ & PUJ-239,240 & 0.0169 & 0.00226 & & & 0 & $105 / 20 / 87$ & SR-90 & 0.398 & 0.0256 \\
\hline & 0 & 1 & $8 / 11 / 83$ & PU-239,240 & 0.0171 & 0.00163 & & & 0 & $106 / 08 / 88$ & SR-90 & 0.339 & 0.0119 \\
\hline & 0 & 1 & $6 / 6 / 84$ & PU-239,240 & 0.00598 & 0.00168 & 0.00187 & & 0 & $105 / 05 / 89$ & SR-90 & 0.261 & 0.0106 \\
\hline & 0 & 1 & $7 / 3 / 85$ & PU-239,240 & 0.0207 & 0.00217 & 0.00316 & & 0 & $106 / 07 / 93$ & SR-90 & 0.105 & 0.0111 \\
\hline & 0 & 1 & $4 / 29 / 86$ & PU-239,240 & 0.00173 & 0.000489 & 0.000522 & & 0 & $108 / 20775$ & CS-137 & 1.55 & 0 \\
\hline & 0 & 1 & $4 / 29 / 87$ & PU-239,240 & 0.00823 & 0.000993 & 0.00131 & & 0 & $108 / 10 / 76$ & CS-137 & 0.395 & 0 \\
\hline & 0 & 1 & $5 / 25 / 88$ & PU-239,240 & 0.00331 & 0.000595 & 0.000683 & & 0 & $106 / 14 / 77$ & CS-137 & 0.973 & 0.09 \\
\hline & 0 & 1 & $5 / 3 / 89$ & PU-239,240 & 0.0173 & 0.00244 & 0.00335 & & 0 & $108 / 10 / 78$ & CS-137 & 0.606 & 0.069 \\
\hline & 0 & 1 & $8 / 13 / 91$ & PU-239,240 & 0.0106 & 0.00112 & 0.00156 & & 0 & $109 / 12 / 79$ & CS-137 & 1.07 & 0.093 \\
\hline & 0 & 1 & $6 / 3 / 93$ & PU-239,240 & 0.00921 & 0.000961 & 0.00133 & & 0 & $108 / 05 / 80$ & CS-137 & 1.18 & 0.1 \\
\hline & 0 & 1 & $8 / 23 / 94$ & PU-239,240 & 0.0055 & 0.00087 & 0.00107 & & 0 & $108 / 13 / 81$ & CS-137 & 0.369 & 0.029 \\
\hline & & & & & & & & & 0 & $108 / 16 / 82$ & CS-137 & 1.13 & 0.103 \\
\hline PROSSER & 0 & 1 & $09 / 24 / 74$ & SR-90 & 0.479 & 0 & & & 0 & 1 $08 / 23 / 83$ & CS-137 & 1.48 & 0.0689 \\
\hline BARRICADE. & 0 & 1 & $08 / 19 / 75$ & SR-90 & 0.177 & 0 & & & 0 & $105 / 24 / 84$ & CS-137 & 0.548 & 0.0427 \\
\hline & 0 & 1 & $06 / 14 / 77$ & SR-90 & 0.113 & 0.0065 & & & 0 & $106 / 12 / 85$ & CS-137 & 1.56 & 0.0688 \\
\hline & 0 & I & $08 / 08 / 78$ & SR-90 & 0.16 & 0.0077 & & & 0 & $105 / 10 / 87$ & CS-137 & 1.08 & 0.0613 \\
\hline & 0 & 1 & $09 / 12 / 79$ & SR-90 & 0.107 & 0.0067 & & & 0 & $106 / 08 / 88$ & CS-137 & 0.988 & 0.0549 \\
\hline & 0 & 1 & $08 / 04 / 80$ & SR-90 & 0.00315 & 0.0068 & & & 0 & $105 / 05 / 89$ & CS-137 & 0.957 & 0.0587 \\
\hline & 0 & 1 & $08 / 11 / 81$ & SR-90 & 0.133 & 0.0074 & & & 0 & $106 / 07 / 93$ & CS-137 & 0.219 & 0.0274 \\
\hline & 0 & 1 & $08 / 16 / 82$ & SR-90 & 0.291 & 0.0184 & & & 0 & $108 / 20 / 75$ & PU-238 & 8E-05 & 0 \\
\hline & 0 & 1 & $08 / 23 / 83$ & SR-90 & 1.11 & 0.0273 & & & 0 & $108 / 10 / 76$ & PU-238 & 0.0005 & 0 \\
\hline & 0 & 1 & $05 / 15 / 84$ & SR-90 & 0.361 & 0.0217 & 0.049 & & 0 & $106 / 14 / 77$ & PU-238 & 0.0002 & 0.0011 \\
\hline & 0 & 1 & $06 / 06 / 85$ & SR-90 & 0.451 & 0.0262 & 0.0915 & & 0 & $108 / 10 / 78$ & PU-238 & -0.001 & 0.0019 \\
\hline & 0 & 1 & $04 / 29 / 86$ & SR-90 & 0.172 & 0.00833 & 0.032 & & 0 & $109 / 12 / 79$ & PU-238 & 0.0018 & 0.0015 \\
\hline & 0 & 1 & $05 / 25 / 88$ & SR-90 & 0.107 & 0.00736 & 0.0216 & & 0 & $108 / 05 / 80$ & PU-238 & 0.0031 & 0.0013 \\
\hline & 0 & 1 & $05 / 03 / 89$ & SR-90 & 0.244 & 0.0114 & 0.0484 & & 0 & $108 / 13 / 81$ & PU-238 & 0.001 & 0.00056 \\
\hline & 0 & 1 & $06 / 07 / 93$ & SR-90 & 0.103 & 0.0121 & 0.0228 & & 0 & $108 / 16 / 82$ & PU-238 & 0,0006 & 0.00062 \\
\hline & 0 & 1 & $09 / 24 / 74$ & CS-137 & 0.906 & 0 & & & 0 & $108 / 23 / 83$ & PU-238 & 0.0016 & 0.00115 \\
\hline & 0 & 1 & $08 / 19 / 75$ & CS-137 & 0.204 & 0 & & & 0 & $105 / 24 / 84$ & PU-238 & 0.0002 & 0.000237 \\
\hline & 0 & 1 & $06 / 14 / 77$ & CS-137 & 0.816 & 0.083 & & & 0 & $106 / 12 / 85$ & PU-238 & 0.0009 & 0.000342 \\
\hline & 0 & 1 & $08 / 08 / 78$ & CS-137 & 0.597 & 0.071 & & & 0 & $105 / 20 / 87$ & PU-238 & 0.001 & 0.000417 \\
\hline & 0 & 1 & $09 / 12 / 79$ & CS- 137 & 0.917 & 0.085 & & & 0 & $106 / 08 / 88$ & PU-238 & 0.0011 & 0.000358 \\
\hline . & 0 & 1 & $08 / 04 / 80$ & CS-137 & 0.945 & 0.08 & & & 0. & $105 / 05 / 89$ & PU-238 & 0.0009 & 0.000327 \\
\hline & 0 & 1 & $08 / 11 / 81$ & CS-137 & 0.214 & 0.023 & & & 0 & $106 / 07 / 93$ & PU-238 & 0.0002 & 0.000147 \\
\hline & 0 & 1 & $08 / 16 / 82$ & CS-137 & 1.19 & 0.0606 & & & 0 & $108 / 20 / 75$ & PU-239,240 & 0.0131 & 0 \\
\hline & 0 & 1 & $08 / 23 / 83$ & CS-137 & 0.767 & 0.0533 & & & 0 & $108 / 1076$ & PU-239,240. & 0.0058 & 0 \\
\hline & 0 & 1 & $05 / 15 / 84$ & CS-137 & 0.152 & 0.0253 & 0.0269 & & 0 & $106 / 14 / 77$ & PU-239,240 & 0.0167 & 0.0035 \\
\hline & 0 & 1 & $05 / 06 / 85$ & $C s=137$ & 0.732 & 0.0488 & 0.0657 & & 0 & $108 / 10 / 78$ & PU-239.240 & 0.0056 & 0.0036 \\
\hline
\end{tabular}


Table B.1. (contd)

\begin{tabular}{|c|c|c|c|c|c|c|c|c|c|c|c|c|c|c|c|}
\hline Sample Site & $\begin{array}{l}\text { Deptl } \\
\text { inche }\end{array}$ & & Date & Constituent & $\begin{array}{l}\text { Result } \\
\text { pCi/g }\end{array}$ & $\begin{array}{l}\text { Countial } \\
\text { Error }\end{array}$ & $\begin{array}{c}\text { Analytical } \\
\text { Error }\end{array}$ & Sample Site & $\begin{array}{l}\text { Dep } \\
\text { ine }\end{array}$ & & Date & Constituent & $\begin{array}{l}\text { Result } \\
\mathrm{pCl} / \mathrm{s}\end{array}$ & $\begin{array}{c}\text { Counting } \\
\text { Error }\end{array}$ & $\begin{array}{c}\text { Anglytical } \\
\text { Error }\end{array}$ \\
\hline \multirow[t]{12}{*}{ ALE (contd) } & 0 & 1 & $09 / 12 / 79$ & PU-239,240 & 0.028 & 0.0048 & & ERC & 1 & 2 & $10 / 25 / 72$ & CS-137 & 0.003 & 0 & \\
\hline & 0 & 1 & $08 / 05 / 80$ & PU-239,240 & 0.023 & 0.0031 & & (contd) & 0 & 1 & $10 / 25 / 72$ & CS-137 & 0.042 & 0 & \\
\hline & 0 & 1 & $08 / 13 / 81$ & PU-239,240 & 0.0101 & 0.0012 & & & 0 & 1 & $10 / 25 / 73$ & CS-137 & 1.26 & 0 & \\
\hline & 0 & & $08 / 16 / 82$ & PU-239,240 & 0.0295 & 0.00242 & & & 0 & 1 & $09 / 24 / 74$ & CS-137 & 0.106 & 0 & \\
\hline & 0 & 1 & $08 / 23 / 83$ & PU-239,240 & 0.0311 & 0.00502 & & & 0 & 1 & $09 / 30 / 71$ & PU-238 & 0 & 0 & \\
\hline & 0 & $i$ & $05 / 24 / 84$ & PU-239,240 & 0.0091 & 0.00139 & 0.0017 & & 1 & 2 & $09 / 30 / 71$ & PU-238 & $\begin{array}{r}0.0032 \\
8\end{array}$ & 0 & \\
\hline & 0 & 1 & $06 / 12 / 85$ & PU-239,240 & 0.0342 & 0.0021 & 0.00389 & & 0 & 1 & $10 / 25 / 72$ & PU-238 & 0 & 0 & \\
\hline & 0 & 1 & $05 / 20 / 87$ & PU-239,240 & 0.0243 & 0.00201 & 0.00334 & & 1 & 2 & $10 / 25 / 72$ & PU-238 & 0.0106 & 0 & \\
\hline & 0 & 1 & $06 / 08 / 88$ & PU-239,240 & 0.0255 & 0.00171 & 0.00312 & & 0 & 1 & $10 / 25 / 73$ & PU-238 & $\begin{array}{r}0.0016 \\
3\end{array}$ & 0.003 & \\
\hline & 0 & 1 & $05 / 05 / 89$ & PU-239,240 & 0.0212 & 0.00156 & 0.00267 & & 0 & 3 & $09 / 24 / 74$ & PU-238 & 0 & 0 & \\
\hline & 0 & 1 & $06 / 07 / 93$ & PU-239,240 & 0.00587 & 0.000709 & 0.000915 & & 1 & 2 & $09 / 30 / 71$ & PU-239,240 & 0.005 & 0 & \\
\hline & & & & & & & & & 0 & 1 & $09 / 30 / 71$ & PU-239,240 & 0.015 & 0 & \\
\hline \multirow[t]{8}{*}{ ERC } & 1 & 2 & $09 / 39 / 71$ & SR-90 & 0.102 & 0 & & & 0 & 1 & $10 / 25 / 72$ & PU-239,240 & 0.009 & 0 & \\
\hline & 0 & 1 & $09 / 30 / 71$ & SR-90 & 0.149 & 0 & & & 1 & 2 & $10 / 25 / 72$ & PU-239,240 & 0.013 & 0 & \\
\hline & 1 & 2 & $10 / 25 / 72$ & SR-90 & 0.0344 & 0 & & & 0 & 1 & $10 / 25 / 73$ & PU-239,240 & 0.0185 & 0 & \\
\hline & 0 & 1 & $10 / 25 / 72$ & SR-90 & 0.0965 & 0 & & & 0 & 1 & $09 / 24 / 74$ & PU-239,240 & $\begin{array}{r}0.0025 \\
4\end{array}$ & 0 & \\
\hline & 0 & 1 & $10 / 25 / 73$ & SR-90 & 0.0757 & 0.00127 & & . & 1 & 2 & $09 / 30 / 71$ & PU & 0.0047 & 0 & \\
\hline & 0 & 1 & $09 / 24 / 74$ & SR-90 & 0.0175 & 0 & & & 0 & 1 & $09 / 30 / 71$ & PU & 0.0147 & 0 & \\
\hline & 1 & 2 & $09 / 30 / 71$ & CS-137 & 0.0643 & 0 & & & 0 & 1 & $10 / 25 / 72$ & PU & $\begin{array}{r}0.0009 \\
37\end{array}$ & 0 & \\
\hline & 0 & 1 & $09 / 30 / 71$ & CS-137 & 0.803 & 0 & & & 1 & 2 & $10 / 25 / 72$ & PU & 0.0131 & 0 & \\
\hline
\end{tabular}


Table B.2. Offsite Sampling Locations

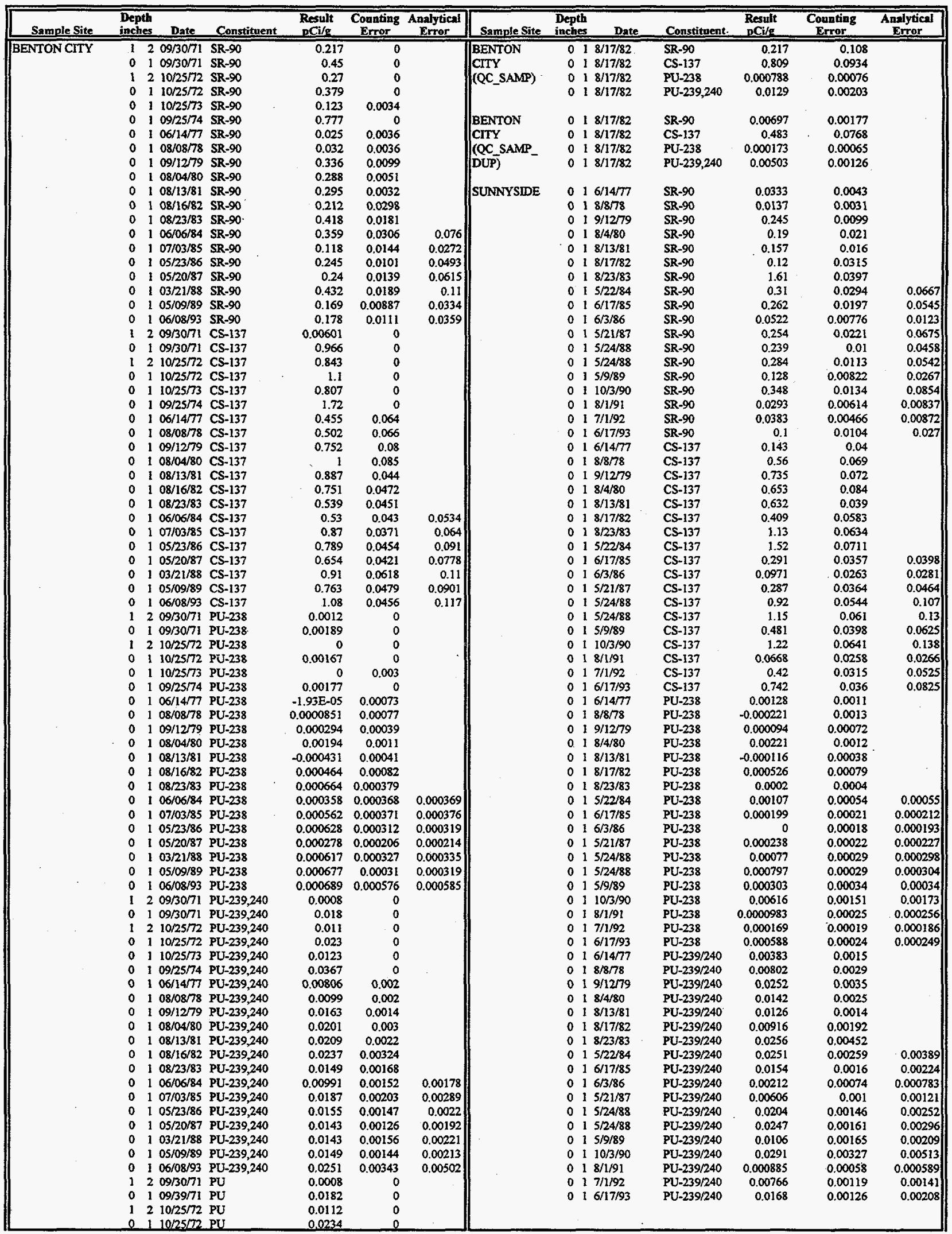


Table B.2. (contd)

\begin{tabular}{|c|c|c|c|c|c|c|c|c|c|c|c|c|}
\hline Sample Site & $\begin{array}{l}\text { Depth } \\
\text { inches }\end{array}$ & Date & Constituent & $\begin{array}{l}\text { Result } \\
\mathrm{PCi} / \mathrm{g}\end{array}$ & $\begin{array}{l}\text { Counnting } \\
\text { Erroor } \\
\end{array}$ & $\begin{array}{c}\text { Analytieal } \\
\text { Error }\end{array}$ & Sample Site & $\begin{array}{l}\text { Depth } \\
\text { inches }\end{array}$ & Date & Constituent & $\begin{array}{l}\text { Result } \\
\mathrm{pCi} / \mathrm{g}\end{array}$ & $\begin{array}{c}\text { Counting } \\
\text { Error }\end{array}$ \\
\hline HARRIS FARM & 01 & $106 / 14 / 77$ & SR-90 & 0.0174 & 0.0034 & & BYERS & 01 & $06 / 19 / 85$ & SR-90 & 0.178 & 0.0164 \\
\hline & 0 & $108 / 09 / 78$ & SR-90 & 0.0354 & 0.0038 & & LANDNG & 01 & $05 / 22 / 86$ & SR-90 & 0.165 & 0.0101 \\
\hline & 0 & $109 / 13 / 79$ & SR-90 & 0.374 & 0.011 & & (contd) & 01 & $105 / 15 / 87$ & SR-90 & 0.0822 & 0.0105 \\
\hline & 0 & $108 / 05 / 80$ & SR-90 & 0.00135 & 0.0068 & & & 01 & $06 / 20 / 88$ & SR-90 & 0.0991 & 0.00612 \\
\hline & 0 & $108 / 2] / 81$ & SR-90 & 0.209 & 0.009 & & & 01 & $105 / 10 / 89$ & SR-90 & 0.125 & 0.00793 \\
\hline & 0 & $108 / 18 / 82$ & SR-90 & 0.115 & 0.0409 & & & 01 & $110 / 04 / 90$ & SR-90 & 0.122 & 0.00956 \\
\hline & 0 & $108 / 18 / 83$ & SR-90 & 0.897 & 0.0437 & & & 01 & 108/08/9i & SR-90 & 0.121 & 0.00813 \\
\hline & 0 & $105 / 30 / 84$ & SR-90 & 0.0391 & 0.0115 & 0.0137 & & 01 & $106 / 23 / 92$ & SR-90 & 0.146 & 0.00855 \\
\hline & 0 & $106 / 19 / 85$ & SR-90 & 0.0741 & 0.0118 & 0.0186 & & 01 & 1 06/29/93 & SR-90 & 0.0874 & 0.0201 \\
\hline & 0 & $105 / 22 / 86$ & SR-90 & 0.0611 & 0.0116 & 0.0159 & & 01 & $108 / 17 / 94$ & SR-90 & 0.146 & 0.014 \\
\hline & 0 & $105 / 15 / 87$ & SR-90 & 0.187 & 0.0135 & 0.0488 & & 12 & $210 / 01 / 71$ & CS-137 & 0.274 & 0 \\
\hline & 0 & $106 / 20 / 88$ & SR-90 & 0.228 & $0: 00939$ & 0.0419 & & 01 & $10 / 01 / 71$ & CS-137 & 1.27 & 0 \\
\hline & 0 & $105 / 08 / 89$ & SR-90 & 0.0685 & 0.0056 & 0.0146 & & 01 & $110 / 25 / 72$ & CS- -137 & 0.836 & 0 \\
\hline & 0 & $108 / 08 / 91$. & SR-90 & 0.145 & 0.0117 & 0.0298 & & 12 & $10 / 25 / 72$ & CS- 137 & 0.881 & 0 \\
\hline & 0 & $107 / 28 / 92$ & SR-90 & 0.0623 & 0.00781 & 0.0139 & & 01 & $10 / 25 / 73$ & CS-137 & 0.765 & 0 \\
\hline & 0 & $106 / 11 / 93$ & SR-90 & 0.0314 & 0.00454 & 0.00768 & & 01 & $109 / 25 / 74$ & CS-137 & 0.694 & 0 \\
\hline & 0 & $108 / 17 / 94$ & SR-90 & 0.0535 & 0.00784 & 0.0152 & & 01 & $108 / 09 / 76$ & CS-137 & 0.201 & 0 \\
\hline & 0 & $106 / 14 / 77$ & CS-137 & 0.165 & 0.042 & & & 01 & 1 $06 / 14 / 77$ & CS-137 & 0.424 & 0.062 \\
\hline & 0 & $108 / 09 / 78$ & CS-137 & 0.501 & 0.066 & & & 01 & $108 / 09 / 78$ & CS-137 & 1.1 & 0.095 \\
\hline & 0 & $109 / 13 / 79$ & CS-137 & 0.352 & 0.057 & & & 01 & $109 / 13 / 79$ & CS-137 & 0.937 & 0.085 \\
\hline & 0 & $108 / 06 / 80$ & CS-137 & 1.09 & 0.085 & & & 01 & $108 / 06 / 80$ & CS-137 & 0.341 & 0.049 \\
\hline & 0 & $108 / 12 / 81$ & CS-137 & 0.463 & 0.033 & & & 01 & $108 / 21 / 81$ & CS-137 & 0.228 & 0.024 \\
\hline & 0 & $108 / 18 / 82$ & CS-137 & 0.489 & 0.0698 & & & 01 & $08 / 18 / 82$ & CS-137 & 0.279 & 0.0745 \\
\hline & 0 & $108 / 18 / 83$ & CS-137 & 1.16 & 0.0653 & & & 01 & $08 / 25 / 83$ & CS-137 & 0.587 & 0.048 \\
\hline & 0 & $105 / 30 / 84$ & CS-137 & 0.0771 & 0.0205 & 0.021 & & $\begin{array}{ll}0 & 1\end{array}$ & $105 / 30 / 84$ & CS-137 & 0.202 & 0.0305 \\
\hline & 0 & $106 / 19 / 85$ & CS-137 & 0.208 & 0.026 & 0.0288 & & 01 & $106 / 19 / 85$ & CS-137 & 0.193 & 0.0347 \\
\hline & 0 & $105 / 22 / 86$ & CS-137 & 0.168 & 0.0358 & 0.0396 & & 01 & $105 / 22 / 86$ & CS-137 & 0.504 & 0.0368 \\
\hline & 0 & $105 / 15 / 87$ & CS-137 & 0.86 & 0.0503 & 0.0996 & & 01 & $05 / 15 / 87$ & CS-137 & 0.227 & 0.0304 \\
\hline & 0 & $106 / 20 / 88$ & CS-137 & 1.3 & 0.0569 & 0.142 & & 01 & $106 / 20 / 88$ & CS-137 & 0.523 & 0.034 \\
\hline & 0 & $105 / 08 / 89$ & CS-137 & 0.451 & 0.0371 & 0.0584 & & 01 & $105 / 10 / 89$ & CS-137 & 0.682 & 0.0425 \\
\hline & 0 & $108 / 08 / 91$ & CS-137 & 1.78 & 0.105 & 0.207 & & 01 & $110 / 04 / 90$ & CS-137 & 0.623 & 0.0451 \\
\hline & 01 & $107 / 28 / 92$ & CS-137 & 0.197 & 0.039 & 0.0436 & & 01 & $108 / 08 / 91$ & CS-137 & 0.597 & 0.0377 \\
\hline & 01 & $106 / 11 / 93$ & CS-137 & 0.118 & 0.0451 & 0.0466 & & 01 & $106 / 23 / 92$ & CS-137 & 0.852 & 0.0377 \\
\hline & 01 & $108 / 17 / 94$ & CS-137 & 0.167 & 0.0805 & 0.0822 & & $\begin{array}{lll}0 & 1\end{array}$ & $106 / 29 / 93$ & CS-137 & 0.581 & 0.0463 \\
\hline . & 01 & $106 / 14 / 77$ & PU-238 & 0.00317 & 0.0028 & & & $\begin{array}{lll}0 & 1\end{array}$ & $108 / 17 / 94$ & CS-137 & 0.158 & 0.0519 \\
\hline . & 0 & $108 / 09 / 78$ & PU-238 & 0.000979 & 0.0013 & & & 01 & $110 / 01 / 71$ & PU-238 & 0.0016 & 0 \\
\hline & 0.1 & $109 / 13 / 79$ & PU-238 & 0.0000589 & 0.00075 & & & 12 & $210 / 01 / 71$ & PU-238 & 0.00244 & 0 \\
\hline & 0 & $108 / 06 / 80$ & PU-238 & 0.000517 & 0.00056 & & & D 1 & $110 / 25 / 72$ & PU-238 & 0.000911 & 0 \\
\hline & 0 & $108 / 12 / 81$ & PU-238 & -0.000358 & 0.0003 & & & 12 & $210 / 25 / 72$ & PU-238 & 0.00288 & 0 \\
\hline$\cdot$ & 01 & $108 / 18 / 82$ & PU-238 & -0.000271 & 0.000633 & & & 01 & $1 \quad 10 / 25 / 73$ & PU-238 & 0.000675 & 0.003 \\
\hline & 01 & $108 / 18 / 83$ & PU-238 & 0.000823 & 0.00106 & & & 01 & $109 / 25 / 74$ & PU-238 & 0.000265 & 0 \\
\hline & 01 & $105 / 30 / 84$ & PU-238 & 0.00226 & 0.00202 & 0.0021 & & 01 & $108 / 09 / 76$ & PU-238 & 0.00136 & 0 \\
\hline & 0 & $106 / 19 / 85$ & PU-238 & 0.000229 & 0.000242 & 0.000243 & & 01 & $106 / 14 / 77$ & PU-238 & 0.000276 & 0.00089 \\
\hline & 0 & $105 / 22 / 86$ & PU-238 & 0.000267 & 0.000197 & 0.000199 & & 01 & $108 / 09 / 78$ & PU-238 & 0.00346 & 0.005 \\
\hline & 01 & $105 / 15 / 87$ & PU-238 & 0.000324 & 0.000194 & 0.000204 & & 01 & $109 / 13 / 79$ & PU-238 & 0.000329 & 0.00072 \\
\hline & 0 & $106 / 20 / 88$ & PU-238 & 0.00105 & 0.000365 & 0.000381 & & 01 & $108 / 06 / 80$ & PU-238 & & \\
\hline & 0 & $105 / 08 / 89$ & PU-238 & 0.000266 & 0.000223 & 0.000225 & & 01 & $108 / 12 / 81$ & PU-238 & -0.000506 & 0.00038 \\
\hline & 0 & $108 / 08 / 91$ & PU-238 & 0.000326 & 0,000322 & 0.000325 & & 01 & $108 / 18 / 82$ & PU-238 & 0.000604 & 0.00087 \\
\hline & 01 & $107 / 28 / 92$ & PU-238 & 0.0000851 & 0.000101 & 0.000103 & & 01 & $108 / 25 / 83$ & PU-238 & 0.000362 & 0.00036 \\
\hline & 0 & 1. $06 / 11 / 93$ & PU-238 & 0.000478 & 0.000271 & 0.000277 & & 01 & $105 / 30 / 84$ & PU-238 & 0.0036 & 0.00294 \\
\hline & 0 & $108 / 17 / 94$ & PU-238 & $-3.21 E-05$ & 0.000703 & 0.000839 & & 01 & $106 / 19 / 85$ & PU-238 & 0.00119 & 0.00045 \\
\hline & 0 & $106 / 14 / 77$ & PU-239,240 & 0.00401 & 0.0029 & & & 01 & $105 / 22 / 86$ & PU-238 & 0.000381 & 0.00021 \\
\hline & 0 & $108 / 09 / 78$ & PU-239,240 & 0.0166 & 0.0034 & & & 01 & $05 / 15 / 87$ & PU-238 & 0.0000659 & 0.00011 \\
\hline & 01 & $109 / 13 / 79$ & PU-239,240 & 0.0167 & 0.0028 & & & 01 & $106 / 20 / 88$ & PU-238 & 0.000652 & 0.00028 \\
\hline & 0 & $108 / 06 / 80$ & PU-239,240 & 0.0157 & 0.0018 & & & 01 & $105 / 10 / 89$ & PU-238 & 0.00142 & 0.00054 \\
\hline & 0 & $108 / 21 / 81$ & PU-239,240 & 0.0109 & 0.0012 & & & 01 & $110 / 04 / 90$ & PU-238 & 0.00111 & 0.00056 \\
\hline & 0 & $108 / 18 / 82$ & PU-239,240 & 0.00644 & 0.00186 & & & 01 & $108 / 08 / 91$ & PU-238 & 0.000417 & 0.00031 \\
\hline & 0 & $108 / 18 / 83$ & PU-239,240 & 0.0208 & 0.00505 & & & 01 & $106 / 23 / 92$ & PU-238 & 0.000854 & 0.00032 \\
\hline & 0 & $105 / 30 / 84$ & PU-239,240 & 0.0018 & 0.0018 & 0.00186 & & 01 & $106 / 29 / 93$ & PU-238 & 0.000436 & 0.00027 \\
\hline & 0. & $106 / 19 / 85$ & PU-239,240 & 0.0052 & 0.000983 & 0,00112 & & 01 & $108 / 17 / 94$ & PU-238 & $-6.04 E-05$ & 0.00087 \\
\hline & 0 & $105 / 22 / 86$ & PU-239,240 & 0.00341 & 0.000636 & 0.000726 & & 12 & $210 / 01 / 71$ & PU-239,240 & 0.008 & 0 \\
\hline & 0 & $105 / 15 / 87$ & PU-239,240 & 0.015 & 0.00123 & 0.00194 & & 01 & $110 / 01 / 71$ & PU-239,240 & 0.012 & 0 \\
\hline & 0 & $106 / 20 / 88$ & PU-239,240 & 0.0216 & 0.00165 & 0.00278 & & $\begin{array}{ll}0 & 1\end{array}$ & $1 \quad 10 / 25 / 72$ & PU-239,240 & 0.006 & 0 \\
\hline & 0 & $105 / 08 / 89$ & PU-239,240 & 0.00791 & 0.00106 & 0.00135 & & 12 & $210 / 25 / 72$ & PU-239,240 & 0.013 & 0 \\
\hline & 0 & $108 / 08 / 91$ & PU-239,240 & 0.0197 & 0.00212 & 0.00314 & & 01 & $110 / 25 / 73$ & PU-239,240 & 0.00524 & 0 \\
\hline & 0 & $107 / 28 / 92$ & PU-239,240 & 0.00427 & 0.000659 & 0.000786 & & 01 & $109 / 25 / 74$ & PU-239,240 & 0.00562 & 0 \\
\hline & 0 & $106 / 11 / 93$ & PU-239,240 & 0.00197 & 0.000528 & 0.00057 & & 01 & $108 / 09 / 76$ & PU-239,240 & 0.00287 & 0 \\
\hline & 0 & $108 / 17 / 94$ & PU-239,240 & 0.00355 & 0.000663 & 0.000773 & & 01 & $106 / 14 / 77$ & PU-239,240 & 0.00554 & 0.0017 \\
\hline & & & & & & & & 01 & $108 / 09 / 78$ & PU-239,240 & 0.000437 & 0.0037 \\
\hline BYERS LANDING & 0 & $110 / 01 / 71$ & SR-90 & 0.098 & 0 & & & 01 & 109/13/79 & PU-239,240 & 0.0182 & 0.0027 \\
\hline & 1 & $210 / 01 / 71$ & SR-90 & 0.098 & 0 & & & 01 & $108 / 06 / 80$ & PU-239,240 & & \\
\hline & 0 & $110 / 25 / 72$ & SR-90 & 0.13 & 0 & & & 01 & $108 / 12 / 81$ & PU-239,240 & 0.00492 & 0.00097 \\
\hline & 12 & $210 / 25 / 72$ & SR-90 & 0.177 & 0 & & - & 01 & $108 / 18 / 82$ & PU-239,240 & 0.00151 & 0.0009 \\
\hline & 0 & $110 / 25 / 73$ & SR-90 & 0.194 & 0.0041 & & & 01 & $108 / 25 / 83$ & PU-239,240 & 0.0116 & 0.00205 \\
\hline & 0 & $109 / 25 / 74$ & SR-90 & 0.247 & 0 & & & 01 & $105 / 30 / 84$ & PU-239,240 & 0.00659 & 0.00398 \\
\hline & 0 & $108 / 09 / 76$ & SR-90 & 0.0216 & 0 & & & 01 & $106 / 19 / 85$ & PU-239,240 & 0.00274 & 0.00063 \\
\hline & 0 & $106 / 14 / 77$ & SR-90 & 0.167 & 0.0077 & & & 01 & $105 / 22 / 86$ & PU-239,240 & 0.0079 & 0.00096 \\
\hline & 0 & $108 / 09 / 78$ & SR-90 & 0.0543 & 0.0047 & & & 01 & $105 / 15 / 87$ & PU-239,240 & 0.00345 & 0.00057 \\
\hline & 0 & $109 / 13 / 79$ & SR-90 & 0.176 & 0.0076 & & & 01 & $106 / 20 / 88$ & PU-239,240 & 0.00975 & 0.00107 \\
\hline & 0 & $108 / 06 / 80$ & SR-90 & 0.00293 & 0.0068 & & & 01 & $105 / 10 / 89$ & PU-239,240 & 0.0138 & 0.00158 \\
\hline & 0 & $108 / 12 / 81$ & SR-90 & 0.0559 & 0.0032 & & & 01 & $110 / 04 / 90$ & PU-239,240 & 0.00901 & 0.00139 \\
\hline & 0 & $108 / 18 / 82$ & SR-90 & 0.0234 & 0.00985 & & & 01 & $108 / 08 / 91$ & PU-239,240 & 0.0133 & 0.00145 \\
\hline & 0 & $108 / 25 / 83$ & SR-90 & 0.304 & 0.0195 & & & 01 & $106 / 23 / 92$ & PU-239,240 & 0.0204 & 0.00155 \\
\hline & 0 & $105 / 30 / 84$ & SR-90 & 0.0642 & 0.09761 & 0.0146 & & 01 & $106 / 29 / 93$ & PU-239,240 & 0.0131 & 0.00147 \\
\hline & & & & & & & & 01 & $108 / 17 / 94$ & $P U-239,240$ & 0.003 & 0.00078 \\
\hline
\end{tabular}


Table B.2. (contd)

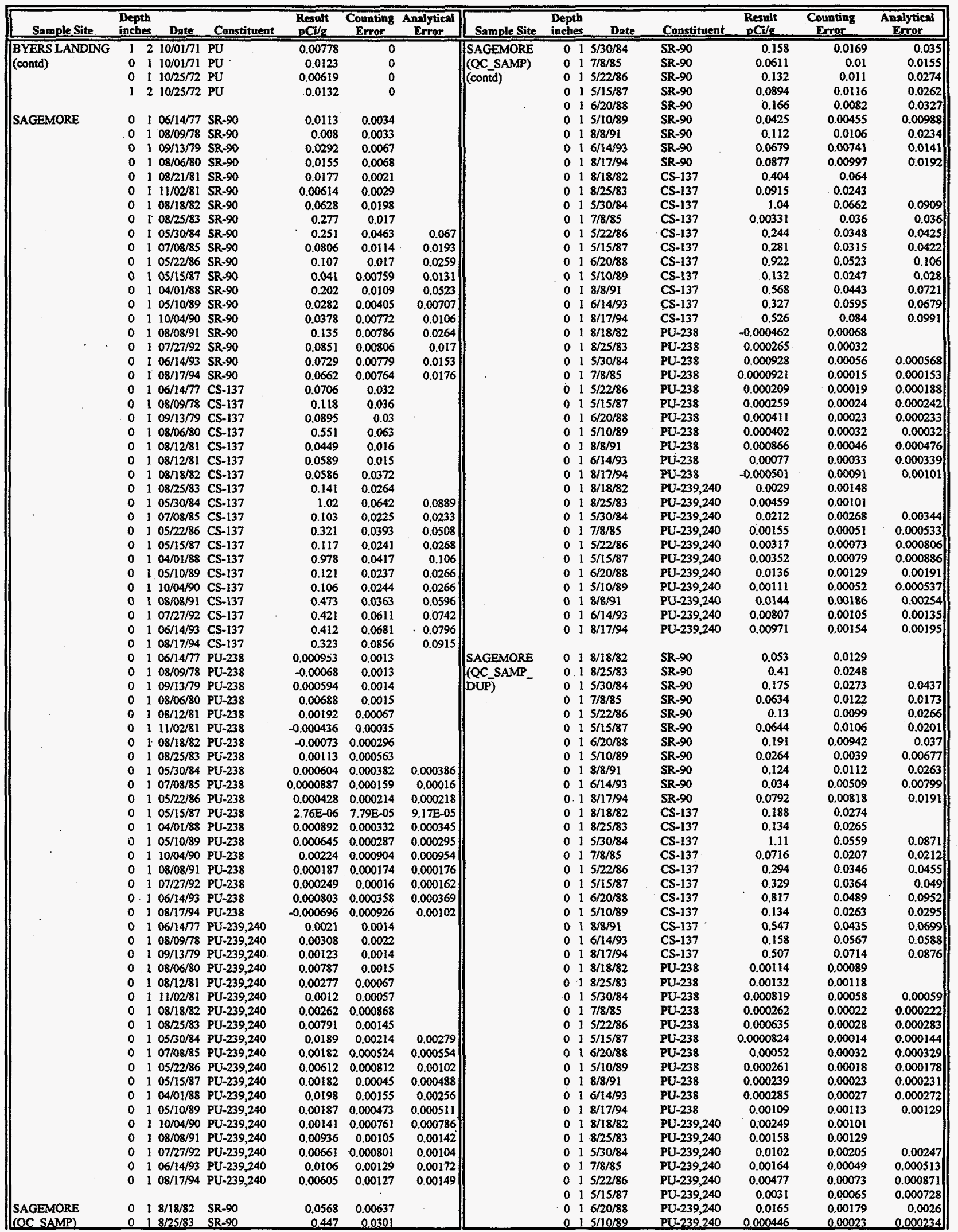


Table B.2. (contd)

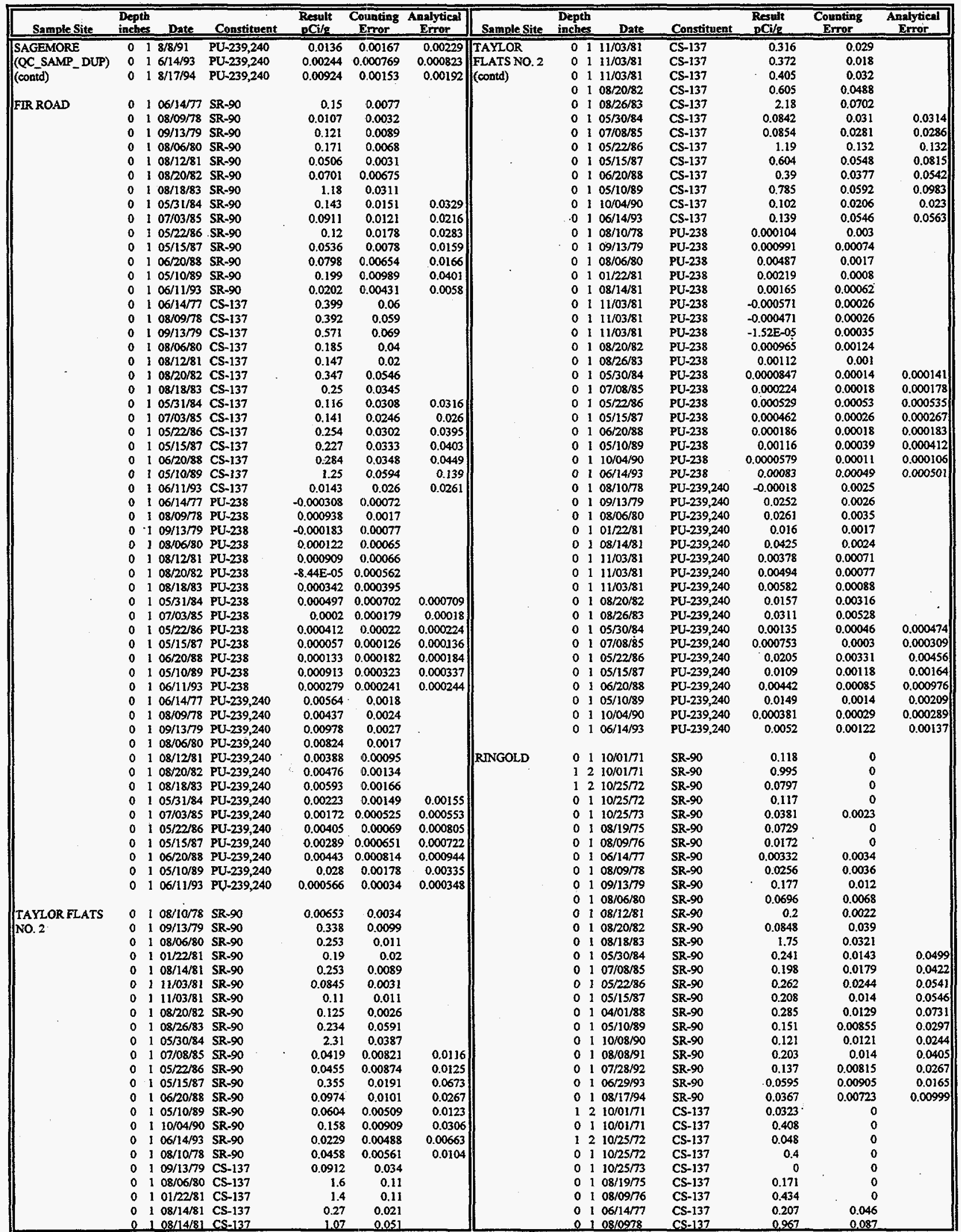


Table B.2. (contd)

\begin{tabular}{|c|c|c|c|c|c|c|c|c|c|c|c|c|c|}
\hline Sample Site & $\begin{array}{l}\text { Dept } \\
\text { inche }\end{array}$ & Date & Constituent & $\begin{array}{l}\text { Result } \\
\mathrm{pCH} / 2\end{array}$ & $\begin{array}{c}\text { Counting } \\
\text { Error }\end{array}$ & $\begin{array}{c}\text { Analytical } \\
\text { Erros }\end{array}$ & Sample Site & $\begin{array}{l}\text { Deptl } \\
\text { inche }\end{array}$ & Date & Constituent & $\begin{array}{l}\text { Resuit } \\
\text { nCi/g }\end{array}$ & $\begin{array}{l}\text { Counting } \\
\text { Error }\end{array}$ & $\begin{array}{c}\text { Anslytical } \\
\text { Error }\end{array}$ \\
\hline RDNGOLD (contd) & 0 & $109 / 13 / 79$ & $\operatorname{CS}-137$ & 0.692 & 0.076 & & BERG & 0 & $108 / 11 / 81$ & SR-90 & 0.108 & 0.0045 & \\
\hline & 0 & $108 / 06 / 80$ & CS-137 & 0.678 & 0.069 & & RANCH & 0 & $108 / 20 / 82$ & SR-90 & 0.203 & 0.091 & \\
\hline & 0 & $108 / 12 / 81$ & CS-137 & 0.938 & 0.048 & & (contd) & 0 & $108 / 26 / 83$ & SR-90 & 0.923 & 0.0226 & \\
\hline & 0 & $108 / 20 / 82$ & CS-137 & 0.826 & 0.0551 & & & 0 & $105 / 30 / 84$ & SR-90 & 0.197 & 0.0189 & 0.0426 \\
\hline & 0 & $108 / 18 / 83$ & CS-137 & 1.56 & 0.0805 & & & 0 & $106 / 26 / 85$ & SR-90 & 0.149 & 0.0168 & 0.0334 \\
\hline & 0 & $105 / 30 / 94$ & CS-137 & 0.444 & 0.0436 & 0.0511 & & 0 & $105 / 02 / 86$ & SR-90 & 0.204 & 0.00926 & 0.0413 \\
\hline & 0 & $107 / 08 / 85$ & CS-137 & 1.12 & 0.0458 & 0.0813 & & 0 & $105 / 26 / 87$ & SR-90 & 0.196 & 0.0136 & 0.0515 \\
\hline & 0 & $105 / 22 / 86$ & CS-137 & 0.398 & 0.0428 & 0.0585 & & 0 & $106 / 10 / 88$ & SR-90 & 0.101 & 0.00691 & 0.0204 \\
\hline & 0 & $105 / 15 / 87$ & CS-137 & 1.02 & 0.0613 & 0.119 & & 0 & $105 / 09 / 89$ & SR-90 & 0.0922 & 0.00659 & 0.0199 \\
\hline & 0 & $104 / 01 / 88$ & CS-137 & 1.78 & 0.0587 & 0.187 & & 0 & $110 / 08 / 90$ & SR-90 & 0.138 & 0.012 & 0.0283 \\
\hline & 0 & $105 / 10 / 89$ & CS-137 & 1.72 & 0.0756 & 0.188 & & 0 & $106 / 09 / 93$ & SR-90 & 0.14 & 0.0114 & 0.0283 \\
\hline & 0 & $110 / 08 / 90$ & CS-137 & 0.583 & 0.0422 & 0.072 & & 1 & $209 / 29 / 71$ & CS-137 & 0 & 0 & \\
\hline & 0 & $108 / 08 / 91$ & CS-137 & 0.726 & 0.0504 & 0.0884 & & 0 & $109 / 30 / 71$ & CS-137 & 0.569 & 0 & \\
\hline & 0 & $107 / 28 / 92$ & CS-137 & 0.947 & 0.0717 & 0.119 & & 1 & $210 / 25 / 72$ & CS-137 & 0.012 & 0 & \\
\hline & 0 & $1.06 / 29 / 93$ & CS-137 & 0.446 & 0.0297 & 0.0536 & & 0 & $110 / 25 / 72$ & CS-137 & 0.226 & 0 & \\
\hline & 0 & $108 / 17 / 94$ & CS-137 & 0.123 & 0.0481 & 0.0497 & & 0 & $110 / 25 / 73$ & CS-137 & 0.822 & 0 & \\
\hline & 0 & $110 / 01 / 71$ & PU-238 & 0.0019 & 0 & & & 0 & $109 / 23 / 74$ & CS-137 & 0.451 & 0 & \\
\hline & 1 & $210 / 01 / 71$ & PU-238 & 0.0029 & 0 & & & 0 & $108 / 19 / 75$ & CS-137 & 0.322 & 0 & \\
\hline & 0 & $110 / 25 / 72$ & PU-238 & 0.00536 & 0 & & & 0 & $108 / 09 / 76$ & CS-137 & 0.295 & 0 & \\
\hline & 1 & $210 / 25 / 72$ & PU-238 & 0.0159 & 0 & & & 0 & $106 / 14 / 77$ & CS-137 & 1.38 & 0.11 & \\
\hline & 0 & $110 / 25 / 73$ & PU-238 & 0.000134 & 0.003 & & & 0 & $108 / 09 / 78$ & CS-137 & 0.548 & 0.068 & \\
\hline & 0 & $108 / 19 / 75$ & PU-238 & 0.00122 & 0 & & & 0 & $109 / 13 / 79$ & CS-137 & 0.863 & 0.085 & \\
\hline & 0 & $108 / 09 / 76$ & PU-238 & 0.000897 & 0 & & & 0 & $108 / 06 / 80$ & CS-137 & 0.582 & 0.064 & \\
\hline & 0 & $106 / 14 / 77$ & PU-238 & 0.00322 & 0.0026 & & & 0 & $108 / 11 / 81$ & CS-137 & 0.396 & 0.024 & \\
\hline & 0 & $108 / 09 / 78$ & PU-238 & 0.00107 & 0.0015 & & & 0 & $108 / 11 / 81$ & CS-137 & 0.485 & 0.038 & \\
\hline & 0 & $109 / 13 / 79$ & PU-238 & 0.00222 & 0.0012 & & & 0 & $108 / 20 / 82$ & CS- 137 & 0.834 & 0.0512 & \\
\hline & 0 & $108 / 06 / 80$ & PU-238 & 0.00152 & 0.00095 & & & 0 & $108 / 26 / 83$ & CS-137 & 0.608 & 0.0453 & \\
\hline & 0 & $108 / 21 / 81$ & PU-238 & 0.000525 & 0.00064 & & & 0 & $105 / 30 / 84$ & CS-137 & 0.494 & 0.0457 & 0.0544 \\
\hline & 0 & $108 / 20 / 82$ & PU-238 & -0.000373 & 0.000632 & & & 0 & $106 / 26 / 85$ & CS-137 & 0.579 & 0.0521 & 0.0626 \\
\hline & 0 & $108 / 18 / 83$ & PU-238 & 0 & 0 & & & 0 & $105 / 02 / 86$ & CS-137 & 0.602 & 0.0454 & 0.0754 \\
\hline & 0 & $105 / 30 / 84$ & PU-238 & 0.000532 & 0.000362 & 0.000365 & & 0 & $105 / 26 / 87$ & CS-137 & 0.31 & 0.0354 & 0.0471 \\
\hline & 0 & $107 / 08 / 85$ & PU-238 & 0.000267 & 0.000275 & 0.000277 & & 0 & $106 / 10 / 88$ & CS-137 & 0.347 & 0.0316 & 0.0469 \\
\hline & 0 & $105 / 22 / 86$ & PU-238 & 0.0000891 & 0.000103 & 0.000103 & & 0 & $105 / 09 / 89$ & CS-137 & 0.453 & 0.0424 & 0.062 \\
\hline & 0 & $105 / 15 / 87$ & PU-238 & 0.00073 & 0.000359 & 0.000372 & & 0 & $110 / 08 / 90$ & CS -137 & 0.637 & 0.0421 & 0.0764 \\
\hline & 0 & $104 / 01 / 88$ & PU-238 & 0.00135 & 0.000443 & 0.000466 & & 0 & $106 / 09 / 93$ & CS-137 & 0.617 & 0.0381 & 0.0725 \\
\hline & 0 & $105 / 10 / 89$ & PU-238 & 0.00196 & 0.000708 & 0.000747 & & 1 & $209 / 29 / 71$ & PU-238 & 0.003 & 0 & \\
\hline & 0 & $110 / 08 / 90$ & PU-238 & 0.00251 & 0.000581 & 0.000637 & & 0 & $109 / 29 / 71$ & PU-238 & 0.0067 & 0 & \\
\hline & 0 & $108 / 08 / 91$ & PU-238 & 0.0015 & 0.000606 & 0.000634 & & 0 & $110 / 25 / 72$ & PU-238 & 0.000601 & 0 & \\
\hline & 0 & $107 / 28 / 92$ & PU-238 & 0.000844 & 0.000366 & 0.000377 & & 1 & $210 / 25 / 72$ & PU-238 & 0.016 & 0 & \\
\hline & 0 & $106 / 29 / 93$ & PU-238 & 0.000637 & 0.000335 & 0.000343 & & 0 & $110 / 25 / 73$ & PU-238 & 0.00133 & 0.003 & \\
\hline & 0 & $108 / 17 / 94$ & PU-238 & 0.000148 & 0.000751 & 0.000891 & & 0 & $109 / 23 / 74$ & PU-238 & 0.000312 & 0 & \\
\hline & 0 & $110 / 01 / 71$ & PU-239,240 & 0.006 & 0 & & & 0 & $108 / 19 / 75$ & PU-238 & -0.00028 & 0 & \\
\hline & 1 & $210 / 01 / 71$ & PU-239,240 & 0.008 & 0 & & & 0 & $108 / 09 / 76$ & PU-238 & 0.00444 & 0 & \\
\hline & 0 & $10 / 25 / 72$ & PU-239,240 & 0.008 & 0 & & & 0 & $106 / 14 / 77$ & PU-238 & 0.00394 & 0.0032 & \\
\hline & 1 & $210 / 25 / 72$ & PU-239,240 & 0.022 & 0 & & & 0 & 1 08/09/78 & PU-238 & -0.000404 & 0.0016 & \\
\hline & 0 & $110 / 25 / 73$ & PU-239,240 & 0.000029 & 0 & & & 0 & $109 / 13 / 79$ & PU-238 & 0.000149 & 0.00076 & \\
\hline - & 0 & $108 / 19 / 75$ & PU-239,240 & 0.00443 & 0 & & & 0 & $108 / 06 / 80$ & PU-238 & 0.00142 & 0.00089 & \\
\hline & 0 & $108 / 09 / 76$ & PU-239,240 & 0.00344 & 0 & & & 0 & $108 / 11 / 81$ & PU-238 & -0.000189 & 0.00034 & \\
\hline & 0 & $106 / 14 / 77$ & PU-239,240 & 0.00464 & 0.0028 & & & 0 & $108 / 11 / 81$ & PU-238 & 0.000431 & 0.00061 & \\
\hline & 0 & $108 / 09 / 78$ & PU-239,240 & 0.0174 & 0.0037 & & & 0 & $108 / 20 / 82$ & PU-238 & -0.000499 & 0.0005 & \\
\hline & 0 & $109 / 13 / 79$ & PU-239,240 & 0.0183 & 0.0029 & & & 0 & $108 / 26 / 83$ & PU-238 & 0.00116 & 0.00085 & \\
\hline & 0 & $108 / 06 / 80$ & PU-239,240 & 0.0179 & 0.0026 & & & 0 & $105 / 30 / 84$ & PU-238 & 0.000391 & 0.00033 & 0.000336 \\
\hline & 0 & $108 / 12 / 81$ & PU-239,240 & 0.0214 & 0.0022 & & & 0 & $106 / 26 / 85$ & PU-238 & 0.000104 & 0.0001 & 0.000105 \\
\hline & 0 & $108 / 20 / 82$ & PU-239,240 & 0.0129 & 0.00243 & & & 0 & $105 / 02 / 86$ & PU-238 & 0.000574 & 0.00041 & 0.000411 \\
\hline & 0 & $108 / 18 / 83$ & PU-239,240 & 0.0277 & 0.00518 & & & 0 & $105 / 26 / 87$ & PU-238 & 0.000142 & 0.00017 & 0.000182 \\
\hline & 0 & $105 / 30 / 84$ & PU-239,240 & 0.00745 & 0.00123 & 0.0014 & & 0 & $106 / 10 / 88$ & PU-238 & 0.000335 & 0.0002 & 0.000206 \\
\hline & 0 & $107 / 08 / 85$ & PU-239,240 & 0.017 & 0.00162 & 0.00236 & & 0 & 1 $05 / 09 / 89$ & PU-238 & 0.000157 & 0.00025 & 0.000246 \\
\hline & 0 & $105 / 22 / 86$ & PU-239,240 & 0.00619 & 0.000857 & 0.00107 & & 0 & $110 / 08 / 90$ & PU-238 & 0.0011 & 0.0005 & 0.000519 \\
\hline & 0 & $105 / 15 / 87$ & PU-239,240 & 0.0168 & 0.00166 & 0.00249 & & 0 & $106 / 09 / 93$ & PU-238 & $0.00029 \mathrm{I}$ & 0.00018 & 0.000186 \\
\hline & 0 & $104 / 01 / 88$ & PU-239,240 & 0.0331 & 0.00218 & 0.00415 & & 1 & $209 / 29 / 71$ & PU-239;240 & 0.003 & 0 & \\
\hline & 0 & $105 / 10 / 89$ & PU-239,240 & 0.0289 & 0.00272 & 0.00443 & & 0 & $109 / 30 / 71$ & PU-239,240 & 0.012 & 0 & \\
\hline & 0 & $110 / 08 / 90$ & PU-239,240 & 0.0112 & 0.00117 & 0.00164 & & 1 & $210 / 25 / 72$ & PU-239,240 & 0.002 & 0 & \\
\hline & 0 & $108 / 08 / 91$ & PU-239,240 & 0.0183 & 0.00214 & 0.00309 & & 0 & $110 / 25 / 72$ & PU-239,240 & 0.007 & 0 & \\
\hline & 0 & $107 / 28 / 92$ & PU-239,240 & 0.0214 & 0.00175 & 0.00287 & & 0 & $110 / 25 / 73$ & PU-239,240 & 0.0158 & 0 & \\
\hline & 0 & $106 / 29 / 93$ & PU-239,240 & 0.00627 & 0.000983 & 0.00119 & & 0 & $109 / 23 / 74$ & PU-239,240 & 0.00715 & 0 & \\
\hline & 0 & $108 / 17 / 94$ & PU-239,240 & 0.00177 & 0.000522 & 0.000568 & & 0 & $108 / 19 / 75$ & PU-239,240 & 0.00818 & 0 & \\
\hline & 0 & $110 / 01 / 71$ & PU & 0.0061 & 0 & & & 0 & $108 / 09 / 76$ & PU-239,240 & 0.00561 & 0 & \\
\hline & 1 & $210 / 01 / 7 \mathrm{I}$ & PU & 0.0084 & 0 & & & 0 & $106 / 14 / 77$ & P.U-239,240 & 0.0268 & 0.0067 & \\
\hline & 0 & $110 / 25 / 72$ & PU & 0.00795 & 0 & & & 0 & $108 / 09 / 78$ & PU-239,240 & 0.00426 & 0.0027 & \\
\hline & 1 & $210 / 25 / 72$ & PU & 0.0224 & 0 & & & 0 & $109 / 13 / 79$ & PU-239, 240 & 0.013 & 0.0026 & \\
\hline & & & & & & & & 0 & $108 / 06 / 80$ & PU-239,240 & 0.00887 & 0.0018 & \\
\hline BERG RANCH & 1 & $209 / 29 / 71$ & SR-90 & 0.34 & 0 & & & 0 & $108 / 14 / 81$ & PU-239,240 & 0.00868 & 0.0015 & \\
\hline & 0 & $109 / 30 / 71$ & SR-90 & 0.34 & 0 & & & 0 & $108 / 11 / 81$ & PU-239,240 & 0.00968 & 0.0011 & \\
\hline & 1 & $210 / 25 / 72$ & SR-90 & 0.07 & 0 & & & 0 & $108 / 20 / 82$ & PU-239,240 & 0.0118 & 0.00233 & \\
\hline & 0 & $110 / 25 / 72$ & SR-90 & 0.202 & 0 & & & 0 & $108 / 26 / 83$ & PU-239,240 & 0.0135 & 0.00284 & \\
\hline & 0 & $110 / 25 / 73$ & SR-90 & 0.322 & 0.0052 & & & 0 & $105 / 30 / 84$ & PU-239,240 & 0.0097 & 0.0015 & 0.00176 \\
\hline & 0 & $109 / 23 / 74$ & SR-90 & 0.0478 & 0 & 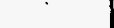 & & 0 & $106 / 26 / 85$ & PU-239,240 & 0.0106 & 0.00105 & 0.00144 \\
\hline . & 0 & $108 / 19 / 75$ & SR-90 & 0.175 & 0 & & & 0 & $105 / 02 / 86$ & PU-239,240 & 0.012 & 0.00151 & 0.00203 \\
\hline & 0 & $108 / 09 / 76$ & SR-90 & 0.0285 & 0 & & & 0 & $105 / 26 / 87$ & PU.239,240 & 0.00612 & 0.00098 & 0.00118 \\
\hline & 0 & $106 / 14 / 77$ & SR-90 & 0 & 0.0034 & & & 0 & $106 / 10 / 88$ & PU-239,240 & 0.0083 & 0.00099 & 0.00131 \\
\hline & 0 & $108 / 09 / 78$ & SR-90 & 0.00972 & 0.0033 & & & 0 & $105 / 09 / 89$ & PU-239,240 & 0.00914 & 0.0018 & 0.00217 \\
\hline & 0 & $109 / 13 / 79$ & SR-90 & 0.301 & 0.0099 & & & 0 & $110 / 08 / 90$ & PU-239,240 & 0.0124 & 0.00144 & 0.00198 \\
\hline & 0 & $108 / 06 / 80$ & SR-90 & 0.141 & 0.0068 & & & 0 & $106 / 09 / 93$ & PU-239,240 & 0.0125 & 0.00109 & 0.00165 \\
\hline & 0 & $108 / 11 / 81$ & SR-90 & 0.107 & 0.0056 & & & 1 & $209 / 29 / 71$ & PU & 0.0026 & 0 & \\
\hline
\end{tabular}


Table B.2. (contd)

\begin{tabular}{|c|c|c|c|c|c|c|c|c|c|c|c|c|c|}
\hline Sample Site & $\begin{array}{l}\begin{array}{l}\text { Depth } \\
\text { inches }\end{array} \\
\text { inte }\end{array}$ & Date & Constituent & $\begin{array}{l}\text { Result } \\
\mathrm{nC} / \mathrm{s}\end{array}$ & $\begin{array}{c}\text { Counting } \\
\text { llirror }\end{array}$ & $\begin{array}{c}\text { Analytical } \\
\text { Errar }\end{array}$ & Sample Site & $\begin{array}{l}\text { Depth } \\
\text { inches }\end{array}$ & Date & Constituent & $\begin{array}{c}\text { Result } \\
\mathrm{pCi} / \mathrm{g}\end{array}$ & $\begin{array}{c}\text { Counting } \\
\text { Error }\end{array}$ & $\begin{array}{c}\text { Analytical } \\
\text { Error }\end{array}$ \\
\hline $\begin{array}{l}\text { BERG RANCH } \\
\text { (contd) }\end{array}$ & $\begin{array}{ll}0 & 1 \\
1 & 2 \\
0 & 1\end{array}$ & $\begin{array}{ll}1 & 9 / 29 / 71 \\
2 & 10 / 25 / 72 \\
1 & 10 / 25 / 72\end{array}$ & $\begin{array}{l}\mathrm{PU} \\
\mathrm{PU} \\
\mathrm{PU}\end{array}$ & $\begin{array}{r}0.012 \\
0.00207 \\
0.00691\end{array}$ & $\begin{array}{l}0 \\
0 \\
0\end{array}$ & & & & & & & & \\
\hline
\end{tabular}


Appendix C

Global Positioning System (GPS) Readings for 20 Long-Term Soil Sampling Locations 


\section{Appendix C}

\section{Global Positioning System (GPS) Readings for 20 Long-Term Soil Sampling Locations}

The Global Positioning System (GPS) reading obtained at each long-term soil sampling site on September 16 and 17, 1996 are listed below. The GPS data are for the Washington State Plane (NAD-83) Coordinate System with meters as the unit of measurement.

Table C.1. GPS Descriptions of Long-Term Soil Sampling Locations

Datum:

Ellipsoid:

Coordinates:

Projection:

SP ZONE:

Units:
NAD-83

GRS80

State Plane NAD-83

Lambert

WASHINGTON SOUTH 4602

METERS

\begin{tabular}{|c|c|c|l||}
\hline \multicolumn{4}{|c|}{ Onsite Sampling Locations } \\
\hline X Position & Y Position & \multicolumn{1}{|c|}{ Date } & \multicolumn{1}{|c|}{ Location Name } \\
\hline 565674 & 156293 & $9 / 16 / 96$ & Wahluke Slope No. 2 \\
\hline 559280 & 138657 & $9 / 16 / 96$ & Yakima Barricade \\
\hline 568447 & 136137 & $9 / 17 / 96$ & East of 200 West Area \\
\hline 573714 & 137817 & $9 / 17 / 96$ & 200 ENC \\
\hline 576315 & 134592 & $9 / 17 / 96$ & 200 ESE \\
\hline 584226 & 139807 & $9 / 17 / 96$ & Hanford Townsite \\
\hline 587939 & 122656 & $9 / 17 / 96$ & SE FFTF \\
\hline 587936 & 123337 & $9 / 17 / 96$ & NE FFTF \\
\hline 585106 & 128238 & $9 / 17 / 96$ & Wye Barricade \\
\hline 583681 & 118275 & $9 / 16 / 96$ & Prosser Barricade \\
\hline 574657 & 118316 & $9 / 17 / 96$ & ALE \\
\hline
\end{tabular}

C. 1 
Table C.1. (contd)

\begin{tabular}{||c|c|c|l||}
\hline \multicolumn{4}{|c|}{ Offsite Sampling Locations } \\
\hline X Position & Y Position & \multicolumn{1}{|c||}{ Date } & \multicolumn{1}{|c|}{ Location Name } \\
\hline 577989 & 111904 & $9 / 16 / 96$ & Benton City \\
\hline 542335 & 118579 & $9 / 16 / 96$ & Sunnyside \\
\hline 596658 & 104928 & $9 / 16 / 96$ & Harris Farm \\
\hline 596616 & 114789 & $9 / 16 / 96$ & Byers Landing \\
\hline 596524 & 116256 & $9 / 16 / 96$ & Sagemoor \\
\hline 595986 & 124268 & $9 / 16 / 96$ & Fir Road \\
\hline 595595 & 120949 & $9 / 16 / 96$ & Taylor Flats No. 2 \\
\hline 595847 & 129571 & $9 / 16 / 96$ & Ringold \\
\hline 588293 & 156850 & $9 / 16 / 96$ & Berg Ranch \\
\hline
\end{tabular}

C. 2 


\section{Distribution}

No. of

Copies

OFFSITE

2 DOE/Office of Scientific and Technical Information

2 Confederated Tribes of the Umatilla Indian Reservation

Environmental Planning/Rights Protection P.O. Box 638

Pendleton, OR 97801

Attn: M. Farrow J. R. Wilkinson

2 Nez Perce Tribe

Environmental Restoration/Waste

Management

P.O. Box 365

Lapwai, ID 83540-0365

Attn: D. Landeen

D. Powaukee

2 Wanapum Indian Band

P.O. Box 878

Ephrata, WA 98823

Attn: R. Buck, Jr.

L. Seelatsee

Washington State Department of Ecology Library

Mail Stop PV-11

Olympia, WA 98504

Attn: J. Yokel

2 Washington State Department of Health Airdustrial Center Building 5, M.S. C-13 Protection

Olympia, WA 98503

Attn: A. W. Conklin

J. Erickson
No. of

Copies

2 Yakima Indian Nation Environmental

Restoration/Waste Management

P.O. Box 151

Toppenish, WA 98948

Attn: B. Bradley

R. Jim

\section{ONSITE}

5 DOE Richland Operations Office

C. R. Briggs

A5-55

J. B. Hall

A.5-15

D. C. Ward

A5-15

Public Reading Room (2)

Bechtel Hanford, Inc.

K. A. Gano

$\mathrm{HO}-02$

Waste Management Federal Services of Hanford, Inc.
A. R. Johnson
H1-13

45

Pacific Northwest National Laboratory

E. J. Antonio

K3-54

R. W. Bryce

K6-91

L. L. Cadwell

K6-84

A. T. Cooper, Jr.

K6-75

R. L. Dirkes (3)

K6-75

B. M. Gillespie

K6-75

R. W. Hanf

K6-75

B. E. Opitz

K6-75

G. W. Patton

K6-75

K. R. Price

K6-75

T. M. Poston (25)

K6-75

R. H. Rickard

K6-84

Information Release Office (7) K1-11 